ALCIDIO PINHEIRO RIBEIRO

\title{
AVALIAÇÃO DO USO DE RESÍDUOS SÓLIDOS INORGÂNICOS DA PRODUÇÃO DE CELULOSE EM MATERIAIS CERÂMICOS
}

São Paulo

2010 


\section{ALCIDIO PINHEIRO RIBEIRO}

\section{AVALIAÇÃO DO USO DE RESÍDUOS SÓLIDOS INORGÂNICOS DA PRODUÇÃO DE CELULOSE EM MATERIAIS CERÂMICOS}

Tese apresentada a Escola Politécnica da Universidade de São Paulo, para obtenção do titulo de Doutor em Engenharia

Área de concentração:

Engenharia Metalúrgica e de Materiais

Orientador:

Prof. Dr. Samuel Marcio Toffoli.

\section{São Paulo}


Autorizo a reprodução e divulgação total ou parcial deste trabalho, por qualquer meio, convencional ou eletrônico, para fins de estudo e pesquisa, desde que citada a fonte.

Este exemplar foi revisado e alterado em relação à versão original, sob responsabilidade única do autor e com a anuência de seu orientador.

São Paulo, 10 de maio de 2010

Alcidio Pinheiro Ribeiro

Autor
Prof. Dr. Samuel Marcio Toffoli

Orientador

\section{FICHA CATALOGRÁFICA}

\section{Ribeiro, Alcidio Pinheiro}

Avaliação do uso de resíduos sólidos inorgânicos da produção de celulose em materiais cerâmicos. São Paulo, 2010.

Tese (Doutorado) - Escola Politécnica da Universidade de São Paulo. Departamento de Engenharia Metalúrgica e de Materiais. Edição Revisada.

1. Reciclagem. 2. Resíduos sólidos. 3. Industria de celulose 4. Industria cerâmica 5. Gestão ambiental.

I. Universidade de São Paulo. Escola Politécnica. Departamento de Engenharia Metalúrgica e de Materiais. II. Avaliação do uso de resíduos sólidos inorgânicos da produção de celulose em materiais cerâmicos. 
Aos meus pais, em minha memória, que me influenciaram a seguir sempre $o$ caminho mais longo e difícil e a apreciar antes o trajeto que o final da estrada. 


\section{RESUMO}

Resíduos sólidos inorgânicos, dregs e grits, gerados no processo de produção de celulose foram caracterizados tecnologicamente e avaliados quanto à viabilidade de serem incorporados na composição de materiais cerâmicos tradicionais. Formulações contendo proporções variadas desses resíduos em uma matriz de argila de emprego na produção de cerâmica vermelha em região próxima de uma fabrica de celulose, no norte do país, foram homogeneizadas, sendo em seguida introduzidas em moldes para produção de corpos de prova regulares. Os corpos de prova gerados foram prensados uniaxialmente e submetidos a queima em diferentes temperaturas. As amostras, tanto secas a $110^{\circ} \mathrm{C}$, como queimadas a 900 e $1000^{\circ} \mathrm{C}$, foram caracterizadas físicamente antes e após a queima ou seja, suas propriedades de interesse cerâmico foram medidas. Os resultados obtidos permitem concluir serem viáveis os usos dos resíduos em teores de cerca de 10\% em massa, na produção de telhas ou tijolos, resultando em componentes com níveis de resistência mecânica apropriados para a finalidade de aplicação destes produtos. Tais resultados somam-se como uma alternativa na melhoria contínua do gerenciamento ambiental desses resíduos pelas indústrias geradoras. Sendo crescentes os níveis de produção de celulose no país e permanentes as preocupações com o meio ambiente, a redução na disposição de tais resíduos em aterros, por incorporação parcial dos mesmos em produtos de interesse regional, contribui para a redução dos impactos sobre o meio ambiente, assim como para a redução no volume de exploração de jazidas minerais.

Palavras chave: resíduos sólidos, dregs, grits, cerâmica, gestão ambiental. 


\begin{abstract}
Inorganic solid wastes, dregs and grits, generated in the cellulosic pulp production, were characterized and their incorporation into the composition of structural ceramics was evaluated. Formulations containing different proportions of such wastes in a clay matrix used for the production of bricks in a region near the pulp mill, in the north of Brazil, were homogenized, and then uniaxially pressed for the production of samples. The specimens were tested after drying at $110^{\circ} \mathrm{C}$ and after firing at the temperatures of 900 and $1000^{\circ} \mathrm{C}$. Their ceramic properties were measured. The results indicated that it is technically viable the use of up to $10 \mathrm{wt} \%$ of the wastes, still reaching adequate level of properties for the use of these products in the civil construction sector. These results show an important alternative for the destination of such wastes, representing an alternative in the continuous improvement of the environmental management of the cellulose production industries. With the increasing levels of cellulose production in the country, and the ongoing concerns about the environment, reduction in the waste disposal in landfills by incorporating them into new products helps to reduce the impacts on the environment and to reduce the volume of exploitation of mineral deposits.
\end{abstract}

Key words: waste, dregs, grits, ceramics, environmental management 


\section{SUMÁRIO}

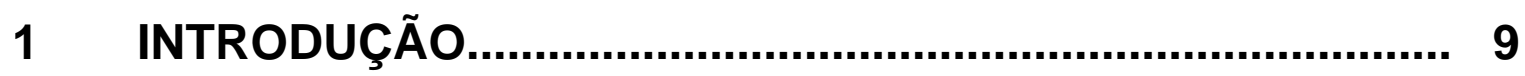

2 REVISÃO DA LITERATURA............................................ 12

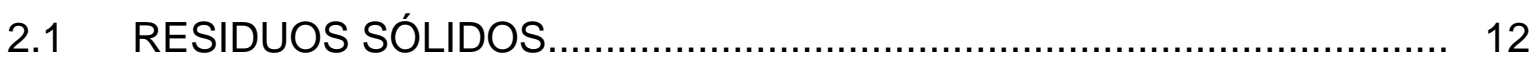

2.1.1 Definições................................................................................. 13

2.1.2 Legislação aplicada..................................................................... 15

2.1.3 Principais destinações.............................................................. 18

2.2 INDUSTRIA DE CELULOSE.......................................................... 20

2.2.1 Matérias primas......................................................................... 27

2.2.2 Processo de produção............................................................... 32

2.2.3 Resíduos sólidos gerados............................................................ 35

2.2.4 Praticas na gestão dos resíduos.................................................. 39

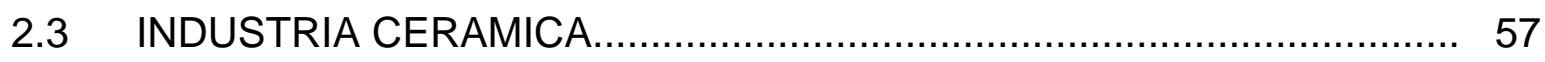

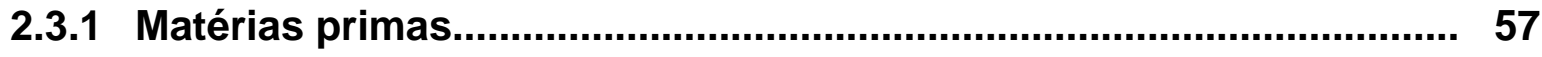

2.3.2 Processo de produção............................................................. 59

2.3.3 Incorporação de resíduos em massas cerâmicas.............................. 59

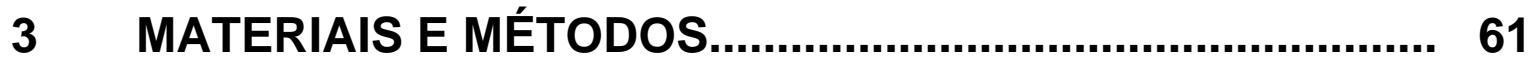

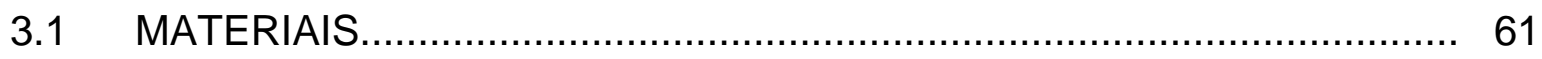

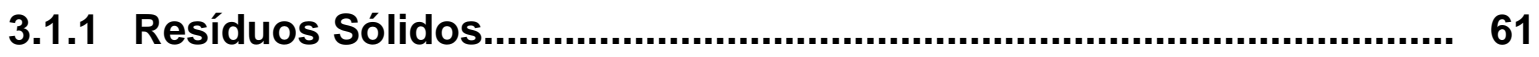

3.1.2 Argila

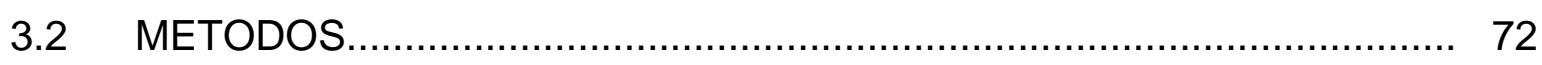

3.2.1 Caracterização física dos materiais................................................. 72

3.2.2 Caracterização química dos materiais............................................. 73

3.2.3 Ensaios cerâmicos...................................................................... 74

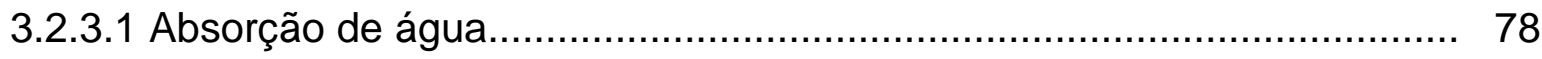

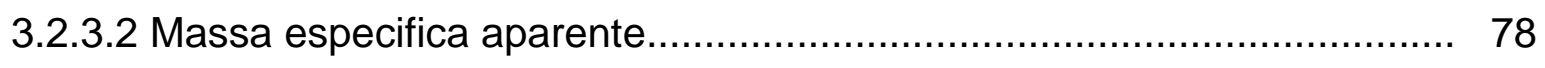

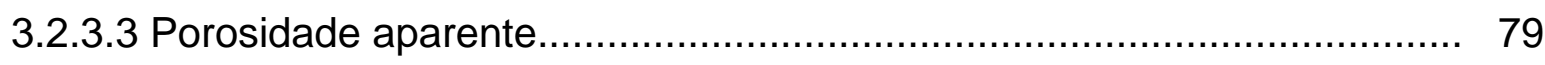

3.2.3.4 Resistência mecânica a flexão.......................................................... 79

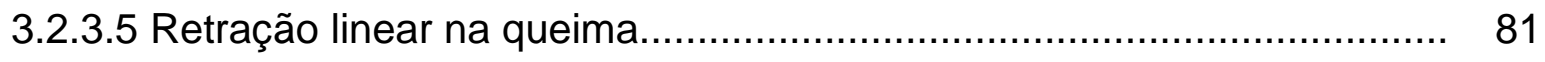


3.2.4 Difração de raios X................................................................... 81

3.2.5 Analise térmica diferencial............................................................ 82

3.2.6 Microscopia eletrônica de varredura................................................. 83

3.2.7 Ensaio de solubilização .............................................................. 83

3.2.8 Teste preliminar de produção........................................................... 85

4 RESULTADOS E DISCUSSÕES........................................ 86

4.1 CARACTERIZAÇÃO FISICA DOS MATERIAIS.................................. 86

4.2 CARACTERIZAÇÃO QUIMICA DOS MATERIAIS............................... 88

4.3. PROPRIEDADES CERAMICAS DAS FORMULAÇÕES GERADAS....... 92

4.3.1 Comportamento dos corpos de prova após secagem a $110^{\circ} \mathrm{C} . . . . . .92$

4.3.1.1 Resistência mecânica.......................................................................... 93

4.3.1.2 Retração linear.................................................................... 94

4.3.2 Comportamento após a queima dos materiais................................ 95

4.3.2.1 Absorção de água após queima...................................................... 96

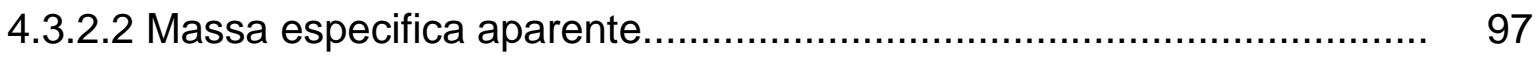

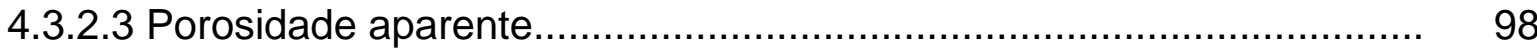

4.3.2.4 Resistência mecânica...................................................................... 100

4.3.2.5 Retração linear...................................................................... 101

4.3.3 Interpretação geral dos ensaios cerâmicos.................................... 102

4.4 DIFRAÇÃO DE RAIOS X......................................................... 104

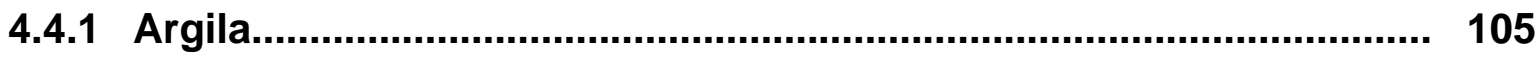

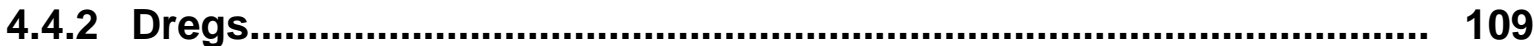

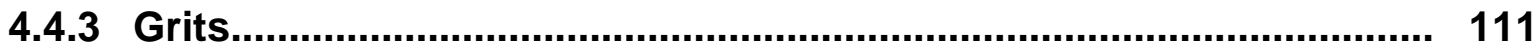

4.4.4 Mistura da argila com os resíduos................................................. 113

4.5 ANALISE TERMICA ............................................................ 114

4.5.1 Argila

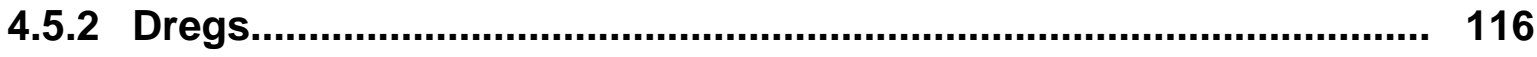

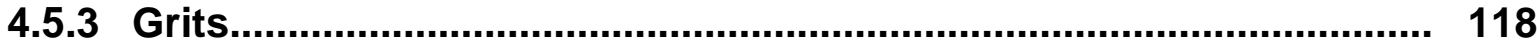

4.5.4 Mistura da argila com os resíduos.................................................. 119

4.5.4.1 Argila com 10\% de resíduos...................................................... 120

4.5.4.2 Argila com 20\% de resíduos..................................................... 121 
4.6 MICROSCOPIA ELETRONICA DE VARREDURA .............................. 123

4.7 ENSAIO DE SOLUBILIZAÇÃO.......................................................... 128

4.8 TESTE PRELIMINAR DE PRODUÇÃO......................................... 129

5 CONCLUSÕES.............................................................. 131

REFERÊNCIAS BIBLIOGRÁFICAS....................................... 133 


\section{INTRODUÇÃO}

Estudos de aplicações de resíduos industriais com vistas a seu aproveitamento em novos produtos tem sido hoje o foco de inúmeras instituições de pesquisa, bem como de interesse generalizado por todos os segmentos geradores, uma vez que a gestão dos mesmos, acumulativamente, constituem custos não desprezíveis, ocupações de espaços crescentes e obrigações com a legislação ambiental em geral.

Por outro lado, a adequação segundo práticas ambientalmente reconhecidas como corretas, como é a redução, a reutilização e a reciclagem de resíduos, não apenas melhora a imagem das empresas que têm investido nessas práticas, mas também leva a resultados econômicos atraentes. Além disso, reduzem o riscos de aumento dos passivos ambientais, assim como de ficarem sujeitas a enquadramentos em situações qualificadas como crimes ambientais.

Os objetos deste estudo foram os resíduos sólidos inorgânicos conhecidos do setor de celulose e papel como dregs (do inglês: escória, sedimento precipitado no fundo de um liquido) e grits (do inglês: grânulo, pedregulho) considerados pela legislação, via de regra, como não inertes, uma vez que apresentam algumas substâncias químicas que podem ser lixiviadas ou solubilizadas sob a ação da água devendo, por isso, serem geridos de forma adequada para se evitar contaminações do solo e da água por essas substâncias.

O setor de produção de celulose brasileiro, gerador dos resíduos em questão, é destaque internacional pelo volume de produção e participação no mercado mundial. Por suas dimensões territoriais e condições climáticas, dentre outros, 0 Brasil vem registrando níveis de crescimento cada vez maiores do segmento. A indústria de celulose demanda uma larga base florestal, necessitando de grandes 
áreas e um clima adequado para o desenvolvimento das espécies que são sua matéria-prima.

Os trabalhos desta tese envolveram resíduos sólidos inorgânicos (dres e grits) gerados pelas empresa Jarí Celulose S.A., situada no município de Almeirim, Distrito de Monte Dourado, Estado do Pará, na divisa com o Estado do Amapá e a avaliação dos resultados da incorporação gradativa dos mesmos em massas de argila utilizadas na produção de peças cerâmicas em pequena indústria localizada no município vizinho amapaense de Laranjal do Jarí.

O crescimento da população na região, desde a implantação do Projeto Jarí por um milionário norte-americano em meados da década de 60 , sempre ocorreu de modo descontrolado, sazonalmente. Isso envolveu deslocamentos populacionais de vários pontos do país, especialmente dos estados do norte e nordeste, em busca dos empregos desse projeto industrial, desde sua instalação, mas até agora, nos períodos de reformas estruturais dessa indústria. Consequência natural dessa situação é que nessa região proliferam-se as construções de madeira improvisadas, casas como palafitas, construídas às margens e sobre as águas do rio Jarí. A possibilidade de se ter materiais básicos de construção, como tijolos cerâmicos, a preços subsidiados, pode contribuir na mudança da qualidade geral das edificações através do aumento relativo de moradias mais seguras e mais salubres, tendo-se, adicionalmente, uma menor pressão exploratória da floresta.

Com esse enfoque, após caracterizar-se os resíduos, foram produzidos corpos de prova utilizando argila local com proporções variadas de resíduos, argila essa de jazida explorada por produtor cerâmico local. Os corpos de prova foram conformados, prensados e queimados. Os materiais produzidos foram sequencialmente testados em suas propriedades cerâmicas. Além disso, as seguintes técnicas foram utilizadas nas avaliações: difração de raios $X$, análise térmica diferencial e termogravimétrica, microscopia eletrônica de varredura e ensaio de solubilização. 
Em síntese, os objetivos deste trabalho foram:

a) Caracterizar tecnologicamente os resíduos dregs e grits, bem como a argila local, empregada para a produção de cerâmica;

b) Avaliar a possibilidade de uso dos resíduos como aditivo na produção de peças cerâmicas tradicionais, comparando as propriedades de amostras com e sem a adição de resíduos;

c) Analisar as conseqüências econômicas, sociais e ambientais dessa rota proposta para a destinação desses resíduos na região onde encontram-se inseridos.

As justificativas principais para seleção dos objetos de estudo foram:

a) As indústrias de celulose geram anualmente milhões de toneladas de resíduos, que por sua natureza deletéria precisam ser adequadamente gerenciados;

b) O setor gerador vem registrando crescimento franco e continuo, o que significa maior geração de resíduos e maiores impactos ambientais;

c) As práticas ambientais corretas, espelhadas na legislação ambiental, exigem que as gestões dos resíduos tenham como metas não somente a redução na geração, mas também o seu reaproveitamento, ao invés de descarte no meio físico. 


\section{REVISÃO DE LITERATURA}

A literatura técnica a respeito dos resíduos sólidos industriais, setores de celulose e de produção cerâmica, é bastante extensa. A importância desses assuntos, pelo que se observa da leitura das obras, artigos, teses, dissertações e notícias, está diretamente associada com a questão ambiental, além da econômica. Procurou-se destacar nesta revisão, trabalhos que tratassem da geração e tratamento dos resíduos sólidos nas indústrias de celulose, definições e classificações, como também os que trouxessem luz sobre o cenário atual das indústrias geradoras e das receptoras desses resíduos, no caso a industria de cerâmica vermelha, produtora de insumos básicos para a construção civil - os tijolos e as telhas.

\subsection{RESÍDUOS SÓLIDOS}

Os resíduos, ou descartes industriais, de modo geral, por constituírem materiais sobre os quais se tem cada vez mais interesse de análise devido sua relação com a questão de proteção do meio ambiente, seja pelo espaço que ocupam, seja por suas composições físico-químicas, vem sofrendo ao longo dos anos um disciplinamento legal cada vez mais rigoroso.

Assim, a preocupação em defini-los é seguida pela de disciplinar sua geração, disposição e monitoramento, manifestadas por meio de uma legislação constantemente revisada e atualizada. Essas práticas são citadas dentro da concepção do que seja uma gestão ambiental. De acordo com DASKALOPOULOS,O.; PROBERT, S.D. (1997) a gestão de resíduos pode ser definida como uma disciplina associada com o controle de sua geração, sua disposicao temporária ou armazenamento, transferência, processamento e disposição final. Ainda para esse autor, ha mais de 10 anos já se buscava minimizar os impactos derivados da gestão de resíduos sólidos. 


\subsubsection{Definições}

Resíduos sólidos são classificados como:

"Resíduos nos estados sólidos e semi-sólidos, que resultam de atividades de origem industrial, doméstica, hospitalar, comercial, agrícola, de serviços e de varrição.

Ficam incluídos nesta definição os lodos provenientes de sistemas de tratamento de água, aqueles gerados em equipamentos e instalações de controle de poluição, bem como determinados líquidos cujas particularidades tornem inviável o seu lançamento na rede pública de esgotos ou corpos de água, ou exijam para isso soluções técnica e economicamente inviáveis em face à melhor tecnologia disponível." (NBR 10.004/04)

Pela norma citada os resíduos são classificados quanto ao risco a saúde publica e ao meio ambiente em dois grupos: perigosos e não perigosos. Os perigosos são colocados na CLASSE I e os não perigosos na CLASSE II. Os não perigosos, por sua vez, são ainda subdivididos em não inertes (CLASSE IIA) e inertes (CLASSE IIB), conforme resumidos na Tabela 2.1.1.1.

Tabela 2.1.1.1 - Classificação de resíduos sólidos segundo a NBR 10.004/04.

\begin{tabular}{|l|l|l|l|r|}
\hline \multirow{2}{*}{$\begin{array}{l}\text { RESIDUOS } \\
\text { SOLIDOS }\end{array}$} & PERIGOSOS & CLASSE I & \multicolumn{2}{|c|}{} \\
\cline { 2 - 5 } & NÃO PERIGOSOS & CLASSE II & A & Não Inertes \\
\cline { 4 - 5 } & & & B & Inertes \\
\hline
\end{tabular}

Os resíduos ditos perigosos, CLASSE I, são assim classificados por apresentarem, por suas propriedades, risco a saúde (morte, doença) e/ou ao meio ambiente. De modo geral são os que têm intrínsecas propriedades de inflamabilidade, corrosividade, reatividade, toxicidade e patogenicidade. 
Os resíduos CLASSE IIA, são considerados "não inertes" por conterem em suas constituições substancias que se solubilizam atingindo níveis acima do valor maximo admitido como seguros para o meio ambiente de acordo com a norma ABNT:NBR 10.004/04. As substancias consideradas para a classificação do resíduo nesta classe encontram-se relacionadas no Anexo $G$ da norma citada, reproduzidas na Tabela 2.1.1.2. Porem, essas substancias não possuem características que poderiam enquadrar os resíduos que as contem como perigoso (Classe I). Entretanto apresentam riscos ao meio ambiente como um todo quando em níveis elevados, alterando a potabilidade, por exemplo, das águas que podem vir a contaminar quando dispostos inadequadamente.

Tabela 2.1.1.2 - Relação de elementos constantes do Anexo G da ABNT:NBR 10004/04. Apresentando o liquido lixiviado/solubilizado do resíduo, para qualquer parâmetro, um valor superior ao maximo aqui indicado, passa o mesmo a ser considerado "não inerte".

\begin{tabular}{|l|r|}
\hline Parâmetro & maximo (mg/l) \\
\hline Alumínio & 0,2 \\
Arsênio & 0,01 \\
Bário & 0,7 \\
Cádmio & 0,01 \\
Chumbo & 0,01 \\
Cloreto & 250 \\
Cobre & 2 \\
Cromo total & 0,05 \\
Ferro & 0,3 \\
Manganês & 0,1 \\
Mercúrio & 0 \\
Prata & 0,05 \\
Selênio & 0,01 \\
Sódio & 200 \\
Sulfato (expresso em SO4) & 250 \\
Zinco & 5 \\
\hline
\end{tabular}

As normas para os ensaios de caracterização dos resíduos por lixiviação ou solubilização são, respectivamente a ABNT:NBR 10.005/04 e a ABNT:NBR 10.006/04. 
Os resíduos CLASSE IIB, por sua vez, não tem nenhum de seus constituintes seja lixiviados ou solubilizados em concentrações superiores aos padrões de potabilidade das águas, excetuando-se aspectos como cor, turbidez, dureza e sabor.

A gestão de resíduos sólidos envolve caracterização, separação e destinação segura, sendo incentivadas, muitas vezes exigidas, praticas que visem a eliminálos, reduzi-los ou reaproveitá-los, de modo a buscar a diminuição de seu impacto sobre o meio ambiente.

\subsubsection{Legislação aplicada}

Por conterem elementos que podem causar impactos ou poluição ambiental, os resíduos sólidos constituem matéria frequente na legislação instituída no âmbito do Ministério do Meio Ambiente.

A legislação ambiental desde a instituição da Política Nacional do Meio Ambiente através da Lei $n^{0}$ 6.938/1981, alterada pela Lei $n^{0} 7.804 / 1989$, disciplina a geração e disposição dos resíduos sólidos no meio onde esta ocorrer.

No Artigo 18 do Decreto n 99.274/1990 que regulamentou a Lei n 6.938/1981 le-se o seguinte:

\footnotetext{
"O órgão estadual do meio ambiente e o IBAMA, este em caráter supletivo, sem prejuízo das penalidades pecuniárias cabíveis, determinarão, sempre que necessário, a redução das atividades geradoras de poluição para manter as emissões gasosas ou efluentes líquidos e os resíduos sólidos nas condições e limites estipulados no licenciamento concedido." (BRASIL. Decreto 99.274, de 6 de junho de 1990)
}

Neste mesmo Decreto, no seu Artigo 34, Inciso III, se previa multa por ação em desacordo com o que fosse estabelecido em lei, como se pode ler na transcrição deste dispositivo feita a seguir: 


\begin{abstract}
"Art. 34 - Serão impostas multas diárias de 61,70 a 6.170 Bônus do Tesouro Nacional BTN, proporcionalmente à degradação ambiental causada, nas seguintes infrações:

III - emitir ou despejar efluentes ou resíduos sólidos, líquidos ou gasosos causadores de degradação ambiental, em desacordo com o estabelecido em resolução ou licença especial;" (BRASIL, op.cit.)
\end{abstract}

A gestão dos resíduos sólidos, que envolve todo o processo desde a sua geração, manuseio, transporte, disposicao final, manutenção, segundo o Conama Conselho Nacional do Meio Ambiente, órgão consultivo e legislativo do Sistema Nacional do Meio Ambiente, instituído através da Política Nacional do Meio Ambiente criada através da Lei 6938/1981 (BRASIL, 1981), através da Resolução Conama no 237 de 1997 (BRASIL, 1997), artigo 2º passou a ser atividade passível de licenciamento ambiental.

Em 1998 com a promulgação da Lei $n^{\circ}$ 9.605, conhecida como Lei de Crimes Ambientais (BRASIL, 1998), ficou estabelecido que o lançamento de resíduos sólidos em desacordo com o que estiver previsto em lei e regulamentos caracterizase como crime ambiental com pena prevista de 1 a 5 anos, como consta no Inciso $\mathrm{V}$, Parágrafo $2^{\circ}$, do seu Artigo $n^{\circ} 54$.

Na Resolução Conama no 307/2002 (BRASIL, 2002), mais especificamente no seu Artigo $2^{\circ}$, Inciso $\mathrm{V}$, le-se que o gerenciamento de resíduos é:

"o sistema de gestão que visa reduzir, reutilizar ou reciclar resíduos, incluindo planejamento,responsabilidades, praticas, procedimentos e recursos para desenvolver e implementar as ações necessárias ao cumprimento das etapas previstas em programas e planos." (BRASIL. Resolução Conama n 307/02).

Na mesma Resolução 307/2002, o Conama define formas de ação na gestão de resíduos como a reutilização (Inciso VI) que vem a ser "o processo de reaplicação de um resíduo, sem transformação do mesmo"; como a reciclagem, esta um 
"processo de reaproveitamento de um resíduo, após ter sido submetido a transformação."

No mesmo dispositivo legal, o Conama define ainda, no Inciso VIII, beneficiamento, como sendo "o ato de submeter um resíduo a operações elou processos que tenham por objetivo dotá-los de condições que permitam que sejam utilizados como matéria-prima ou produto."

Ainda em 2002, o Conama, através da sua Resolução no 313 (BRASIL, 2002b), institui a Política Nacional de Resíduos Sólidos - PNRS, instrumento que se justificava porque:

- havia ausência de informações precisas sobre a quantidade, os tipos e os destinos dos resíduos sólidos gerados no parque industrial do país;

- os resíduos podem apresentar características prejudiciais à saúde humana e ao meio ambiente;

- os volumes dos resíduos tem geração crescente nos cenários onde são gerados e a também crescentes áreas que ocupam no meio ambiente,

Através da PNRS, o Conama instituiu o Inventario Nacional de Resíduos Sólidos que deveria ser conduzido pelos órgãos ambientais estaduais e encaminhados ao IBAMA em 2 anos e, posteriormente, atualizados na mesma freqüência, isto é, em 24 meses.

O Inventário Nacional de Resíduos Sólidos, de acordo com o previsto no Inciso II do Art. $2^{\circ}$ (BRASIL, op.cit.), "é o conjunto de informações sobre a geração, características, armazenamento, transporte, tratamento, reutilização, reciclagem, recuperação e disposição final dos resíduos sólidos gerados pelas indústrias do país." 
No art. 29 da Resolução Conama n0357 de 2005 (BRASIL, 2005), le-se que: " $\boldsymbol{A}$ disposição de efluentes no solo, mesmo tratados, não poderá causar poluição ou contaminação das águas."

Como se vê na estrutura legislativa do Brasil, que trata do disciplinamento no âmbito ambiental, os resíduos sólidos industriais são objetos de controle e atualizações freqüentes, exigindo-se das empresas que o gerem uma clareza nas informações sobre a natureza, qualidade e quantidade dos mesmos, para o devido licenciamento de suas atividades e operações.

\subsubsection{Principais destinações}

As destinações mais tradicionais no tratamento dos resíduos sólidos são:

- Aterros controlados;

- Incineração;

- Reciclagem.

A disposição em aterros sobre terrenos naturais sem tratamento da superfície que o recebe, como a sua impermeabilização, por exemplo, são formas controladas de armazenar os resíduos que não tenham em sua composicao elementos que possam de forma imediata ou futura vir a contaminar o meio ambiente, solo e água superficial ou subterrânea. Para tanto, essa forma de disposição, no seu licenciamento pelos órgãos ambientais, exige-se a comprovação de ser o material inerte.

Por outro lado, a disposição em aterros exige também que ocorra de modo geotecnicamente estável e seguro, isto é, que o amontoado de materiais sejam dispostos sob praticas e formas que garantam sua estabilidade, não suscetíveis ao desencadeamento de processos erosivos, o que poderia ocasionar a contaminação de águas superficiais, mesmo que apenas por aumento de turbidez, das bacias onde se situem. 
Como se vê, a disposição em aterros controlados constitui operação de custo relativamente elevado, uma vez que se deve ter em conta também a demanda de extensas áreas de terra para sua deposição, que tem seu valor e precisa possuir dimensões e formas de relevo adequadas a estabilização dos depósitos que se acumularão no local, e o exercício de técnicas de deposição com acompanhamento de profissional capacitado, com uso de maquinas e equipamentos adequados, para sua formação e conformação, constituindo em dispendiosos pagamentos por horas de maquinas, supervisores e operadores. DASKALOPOULOS et al. (1997) estimava os custos por tonelada de disposição de resíduos em aterros variável entre US\$10 a US\$ 25 por tonelada.

Tem-se que considerar também, que após se exaurir a capacidade de deposição no sitio utilizado, o empreendedor terá que recuperar ambientalmente a área, com reposição de material que irá formar um novo solo, sua vegetação, alem de se responsabilizar pela manutenção do sistema implantado, de acordo com exigências contidas nas licenças concedidas. Alem disso, o empreendedor responsável pelo aterro deve monitorar o lençol de água subterrânea através de analises rotineiras para comprovar junto aos órgãos públicos responsáveis pelo meio ambiente que águas pluviais não carrearam via infiltração e acumularam substancias nocivas sob determinadas concentrações, que possam estar contida nos resíduos, para o lençol subterrâneo, como se pode ver em COSTA et al. (2009).

Caso ocorra diagnostico de contaminação, a correção e tratamento do material depositado devem ser imediatas, como apregoa a lei, em especial a Resolução Conama $n^{\circ} 357 / 05$ no seu Art. 24 , onde se le que:

\footnotetext{
"os efluentes de qualquer fonte poluidora somente poderão ser lançados, direta ou indiretamente, nos corpos de água, após o devido tratamento e desde que obedeçam às condições, padrões e exigências dispostos nesta Resolução e em outras normas aplicáveis." (BRASIL. Resolução Conama nº 357 de 17 de março de 2005).
}

A contaminação, ou a poluição, do meio ambiente é diagnosticada quando ha concentrações de determinados elementos acima dos teores máximos definidos na legislação, elencados na Resolução Conama 357/05 (BRASIL, op. cit). 
A incineração para os resíduos estudados não seria alternativa pratica por serem materiais não inflamáveis, como são principalmente resíduos com elevado conteúdo de orgânicos, dentre outros, para os quais seja factível tal destinação.

A reciclagem é o reaproveitamento do material de descarte para um uso útil, que pode ser no próprio processo industrial ou não. É considerada uma modalidade adequada de destinação de resíduos de forma geral porque colabora com a redução da ocupação de espaços físicos e dos riscos que podem ser inerentes ao acumulo dos resíduos com meio ambiente.

De acordo com o IBGE (2008) o grau de reciclagem de resíduos de uma forma geral é um indicador de desenvolvimento sustentável de uma industria, segmento, país. De acordo com a instituição na mesma publicação:

\begin{abstract}
A reciclagem de materiais é uma das questões mais importantes no gerenciamento sustentável de resíduos. Ao lado da reutilização e da redução da geração de resíduos, é uma das atividades-chave para o enfrentamento do desafio representado pelo destino final dos resíduos sólidos, compondo a mundialmente conhecida estratégia dos três $\mathrm{R}$ (reduzir, reutilizar, reciclar). (BRASIL. IBGE, 2008).
\end{abstract}

O aumento nos preços das matérias-primas e da energia, associado a legislações relativas ao meio ambiente nos foros municipais, estaduais e federais cada vez mais restritivas, tentem a fazer com que os índices de reciclagem de todos os materiais hoje descartáveis cresçam ininterruptamente.

\title{
2.2 INDÚSTRIA DA CELULOSE
}

O IBGE - Instituto Brasileiro de Geografia e Estatística classifica a industria de celulose em sua Classificação Nacional de Atividades Econômicas - CNAE, como a relativa a Divisão, 17; Grupo, 17.1; Classe 17.10-9, onde se agrupa as empresas responsáveis pela "Fabricação de celulose e outras pastas para a fabricação de papel". 
O segmento de celulose e papel é um dos principais setores da cadeia produtiva de produtos florestais (Figura 2.2.1) onde a madeira em tora é a sua material prima. $O$ setor de celulose e papel brasileiro, na atualidade, se utiliza $100 \%$ de florestas plantadas, $0 \%$ de florestas nativas.

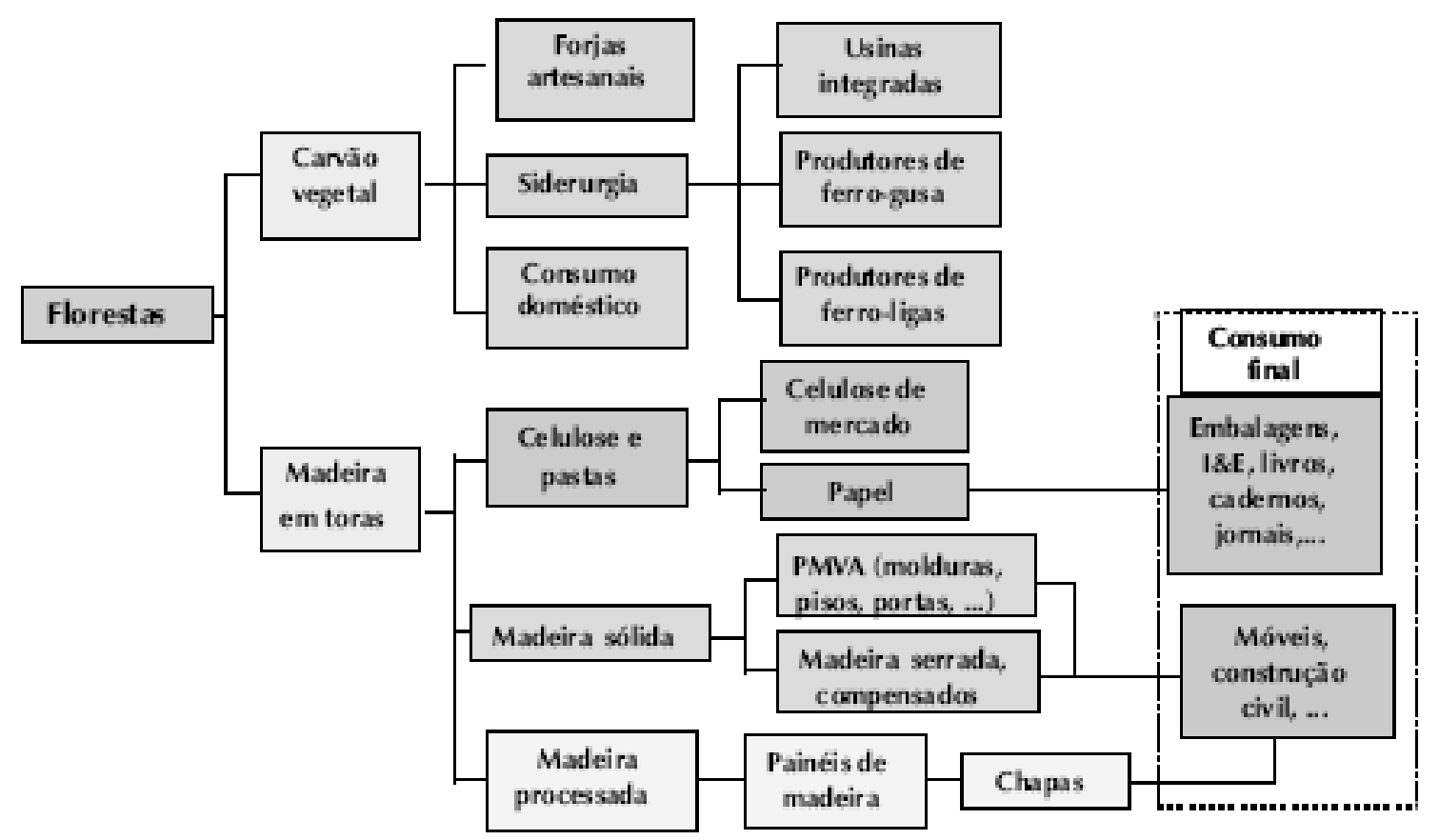

Figura 2.2.1 - Cadeia produtiva do setor florestal de acordo com DORES et al. (2007)

A produção industrial de celulose, no Brasil, iniciou-se a partir do aproveitamento de espécies nativas, como o pinheiro, no Estado do Paraná, em Monte Alegre, no início dos anos 40 do século passado.

A produção em grande escala principalmente de celulose de Eucalipto, e, secundariamente de pinus, espécies exóticas trazidas da Oceania e Europa respectivamenteo, exótica, foi iniciada no Estado de São Paulo, em 1957, estabelecendo-se o caminho para a grande etapa de industrialização da celulose que, em menos de um quarto de século, levou o Brasil a posição de $6^{\circ}$. produtor do mundo, conforme divulgado pela Bracelpa (2010), com uma produção em 2007 de praticamente 12 milhões de toneladas de celulose. 
O Eucalipto, que tem origem atribuída a Austrália, chegou ao Brasil como matéria prima para produção de dormentes. De rápido crescimento, especialmente no Brasil, o Eucalipto é o principal elemento das áreas de reflorestamento.

O número de empresas foi crescendo à medida que aumentavam o mercado consumidor e a demanda, não somente local, mas, principalmente, mundial. Entretanto, por serem empresas de capital intensivo e elevado, o impulso dado por planos de incentivo federais foi essencial para o seu desenvolvimento.

Os primeiros investimentos significativos no setor surgiram com o Plano de Metas do Governo Kubitschek (1956-1960), seguindo o modelo clássico de substituição das importações.

Os maiores saltos no crescimento do setor no Brasil se deram através de planos de desenvolvimento do governo federal, denominados de Plano Nacional de Papel e Celulose (PNPC). Durante o $1^{\circ}$ PNPC, da década de 70, assistiu-se a constituição da Aracruz Celulose, hoje a maior produtora mundial de celulose. No $2^{\circ}$ PNPC, década de 80, assistiu-se ao surgimento da Bahia Sul Celulose, Inpacel, e da Companhia Florestal Monte Dourado (Projeto Jarí), atualmente Jarí Celulose S.A..

O setor hoje emprega na ordem de 110 mil pessoas (Bracelpa, 2008) e possui uma cadeia produtiva bastante complexa, que abrange as etapas de reflorestamento, produção, corte e transporte de madeira, fabricação de celulose, fabricação de papel, conversão de papel em artefatos, como embalagens, produção gráfica, produção editorial e reciclagem do papel utilizado. Além disso inclui atividades de geração de energia, distribuição, comércio, exportação e transportes rodoviário, ferroviário e marítimo, de matérias primas e produtos.

Os maiores produtores mundiais de celulose são os EUA, Canadá e China (Tabela 2.2.1). A produção mundial de celulose encontra-se atualmente na casa de 200.000.000 toneladas, tendo o Brasil uma participação atual da ordem de $6 \%$ desse mercado, o que pode se dizer muito baixa haja vista nossa natural vocação para produção nessa área, pela extensão territorial e clima favoráveis ao desenvolvimento de espécies florestais. 
O Brasil, com 8.547.906 km² de área superficial, produz menos que países como Finlândia e Suécia, cujas áreas que ocupam, são, respectivamente, 338.145 e $449.964 \mathrm{~km}^{2}$

Tabela 2.2.1 - Maiores produtores mundiais de celulose e de papel de acordo com a Bracelpa (2008).

\begin{tabular}{|cc|lc|}
\hline \multicolumn{2}{c|}{ CELULOSE } & \multicolumn{2}{c}{ PAPEL } \\
\hline \multicolumn{1}{c|}{ País } & $1000 \mathrm{t}$. & \multicolumn{1}{c}{ País } & $1000 \mathrm{t}$. \\
\hline 1. EUA & 53.215 & 1. EUA & 84.073 \\
2. Canadá & 23.677 & 2. China & 65.000 \\
3. China & 18.160 & 3. Japão & 31.106 \\
4. Finlândia & 13.066 & 4. Alemanha & 22.655 \\
5. Suécia & 12.240 & 5. Canadá & 18.170 \\
6. Brasil & 11.998 & 6. Finlândia & 14.151 \\
7. Japão & 10.884 & 7. Suécia & 12.066 \\
8. Rússia & 7.370 & 8. Coréia do Sul & 10.703 \\
9. Indonésia & 5.672 & 9. Itália & 10.009 \\
10. Chile & 3.550 & 10. França & 10.006 \\
11. Índia & 3.250 & 11. Brasil & 9.008 \\
& & 12. Indonésia & 8.862 \\
\hline TOTAL MUNDO & 192.177 & & 381.551 \\
\hline
\end{tabular}

A demanda mundial de celulose por industrias produtoras de papel e demais artefatos, não integradas, isto é, que não possuem produção própria de celulose, encontra-se na ordem de 45 milhões de toneladas anuais.

Os principais produtores nacionais de celulose dita "de mercado", isto é a celulose que não se destina para a produção integrada de papel, mas para suprir produtores destes materiais a nível mundial, são a Aracruz Celulose, Veracel, Cenibra, Bahia Sul, VCP, Jarí, Riocell,

O crescimento da produção nacional vem se dando a níveis cada vez mais elevados ao longo dos últimos anos como pode se ver na Figura 2.2.2. No período registrado nesse gráfico é destaque que na ultima década do século passado a produção de celulose crescia cerca de 300.000 toneladas/ano, tendo passado, no inicio desse século, para uma taxa superior a 600.000 toneladas/ano. 


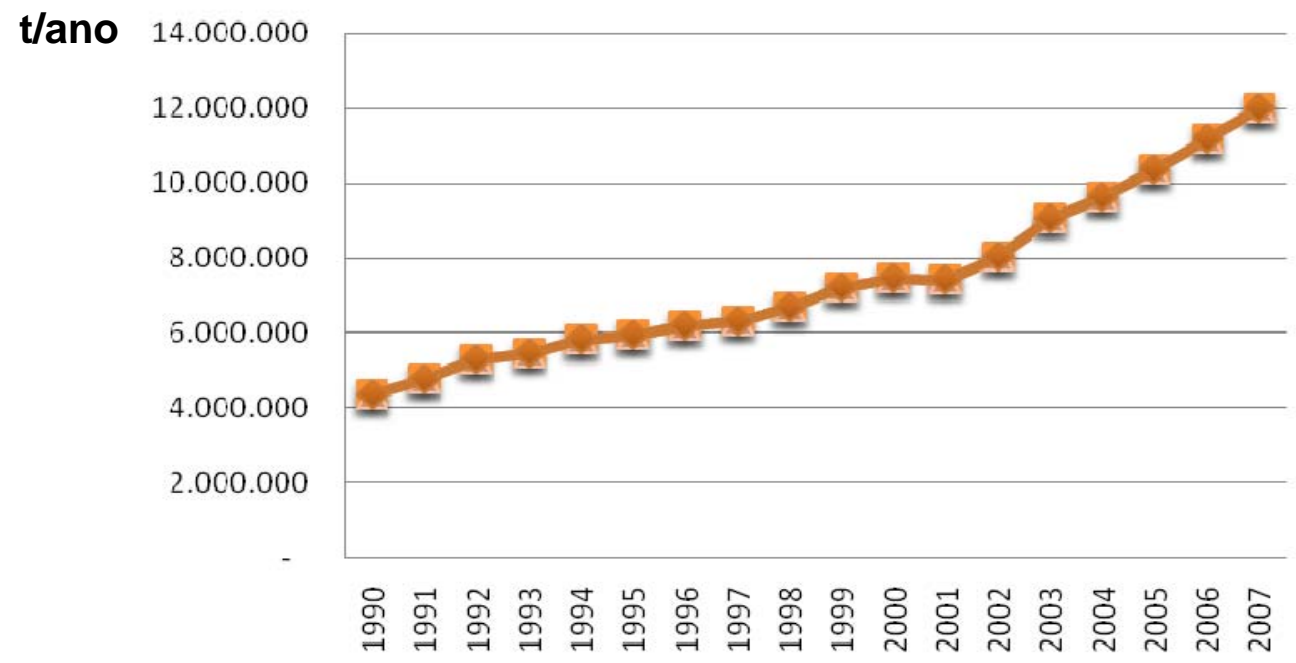

Figura 2.2.2 - Evolução nos últimos 17 anos da produção de celulose no Brasil de acordo com a Bracelpa (2008).

Esse comportamento foi fruto do crescimento da demanda mundial, cuja pressão de compra refletiu no aumento significativo no preço da celulose, que saiu de valores da ordem de US\$ 500/tonelada por volta de 2001, para US\$ 800/tonelada em 2008.

O setor de celulose e papel distribui-se em um universo da ordem de 200 unidades fabris, distribuídas em 17 estados e em 450 municípios. Com uma base florestal construída predominantemente por eucaliptos (75\%) e pinus (25\%), o segmento exporta mais de $\mathrm{R} \$ 4$ bilhões anualmente de seus produtos. Segundo a Bracelpa (op. cit), no próximo biênio o setor planeja investimentos de da ordem de US\$2,0 bilhões em expansão de capacidade.

A distribuição geográfica das maiores indústrias de celulose brasileiras pode ser vista na Figura 2.2.3. 


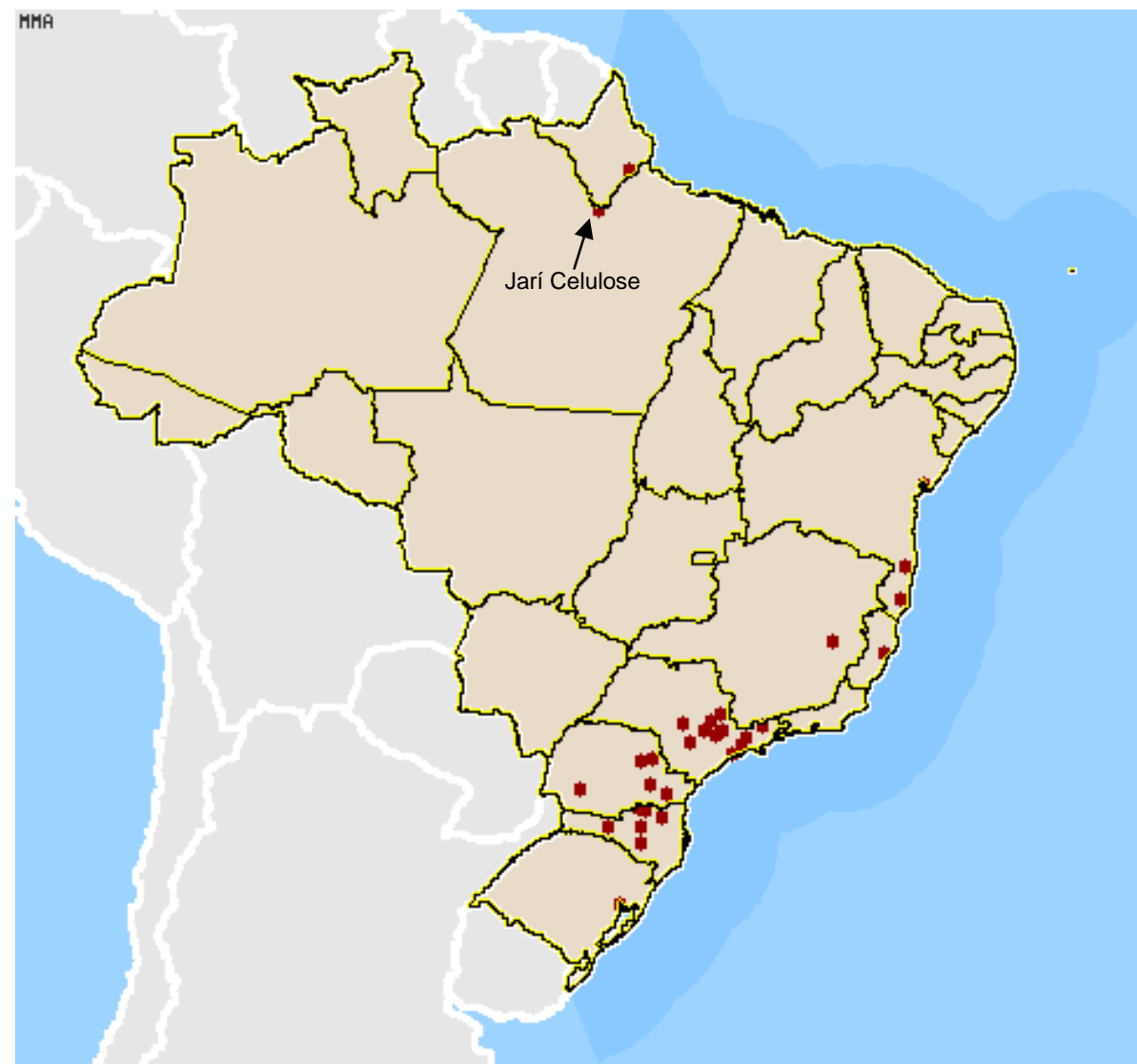

Figura 2.2.3 - Distribuição geográfica dos principais produtores de celulose destacando-se a Jarí Celulose, de onde foram obtidos os resíduos para esta tese. (BRASIL. MINISTERIO DO MEIO AMBIENTE, 2010),

Em termos de volumes de produção, na Figura 2.2.4 estão representadas as participações de cada unidade da federação. A região sudeste é a grande produtora nacional, ultrapassando 60\% da produção brasileira.

Devido a ser intensiva em capital, exigindo grandes investimentos em imobilizados, como imóveis rurais com grandes extensões em área para produção da matéria prima, equipamentos específicos, verifica-se que há certa concentração neste segmento em poucos praticantes, que, cada vez mais, procuram aumentar suas capacidades instaladas para melhor competir economicamente. 


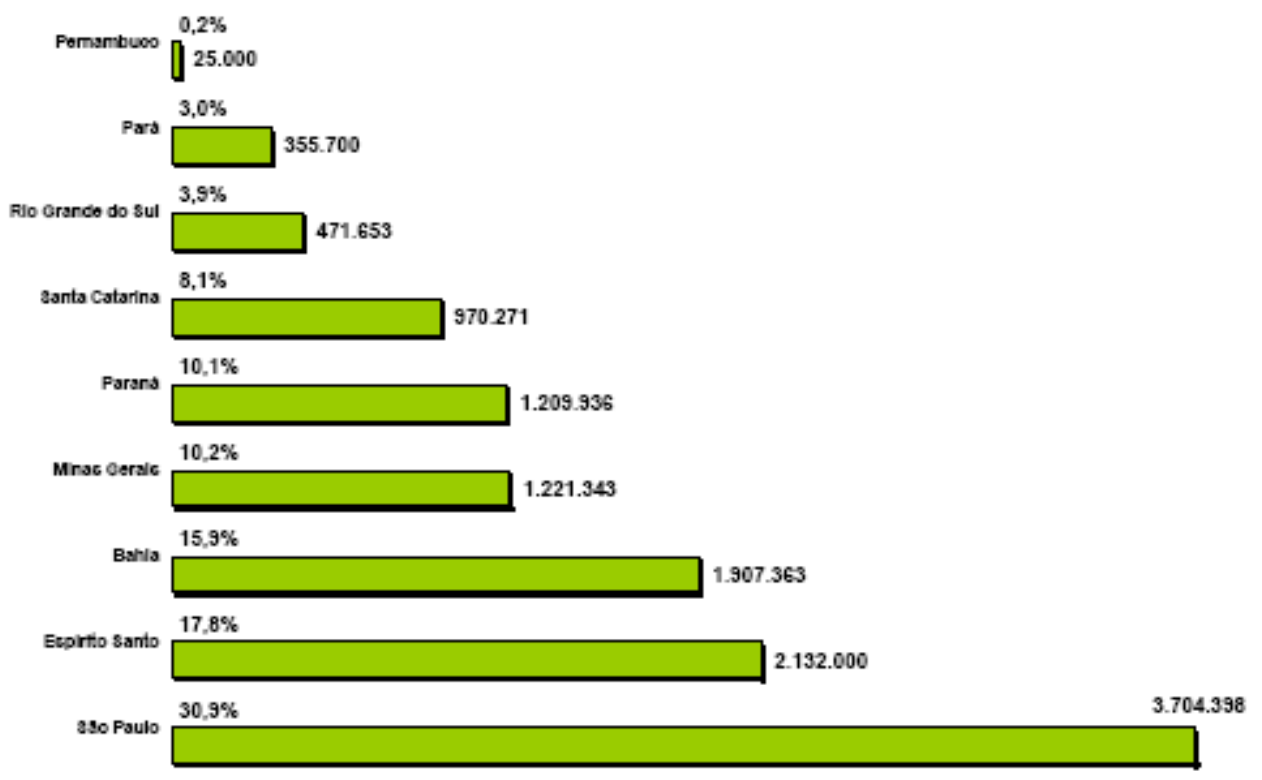

Figura 2.2.4 - Distribuição nacional da produção de celulose (Bracelpa, 2008)

Os principais compradores da celulose brasileira são os EUA, Japão, Bélgica, Reino Unido, Itália, França, Coréia e China. Os três primeiros consomem cerca de $60 \%$ de toda a exportação brasileira.

A produção brasileira de papel em 2007 atingiu 8,97 milhões de toneladas, incluindo todos os tipos (Figura 2.2.5). Relativamente à produção de celulose, o índice de crescimento da produção de papel foi significadamente menor.

Conforme se vê no gráfico que registra a evolução na produção de papel no Brasil, o crescimento registrado tem uma linha de tendência linear, a uma taxa similar ao do crescimento do PIB brasileiro, da ordem de 3\% a.a. Isso reflete que nossa produção de papel, ao contrário da de celulose, tem como destino principalmente o mercado interno. 


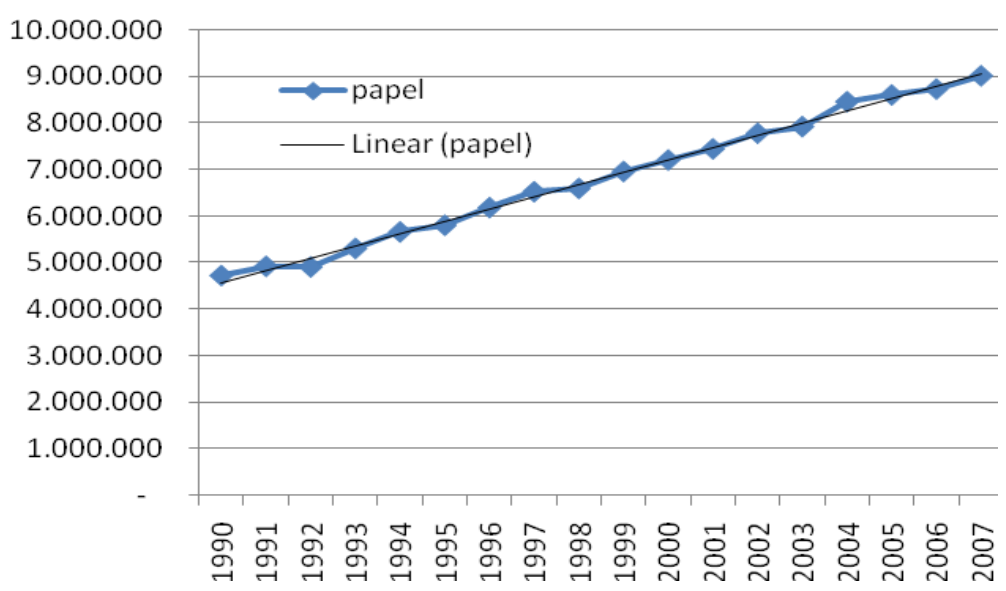

Figura 2.2.5 - Evolução na producao de papel no Brasil no Brasil (Bracelpa, 2008).

No entanto, DORES et al.(2007) destaca que:

"há um grande espaço de crescimento da demanda interna de papel de todos os tipos, que depende do crescimento da economia do país, dadas as baixas taxas de consumo per capita de papel no Brasil quando comparadas a outros países (39,5 kg/habitante/ano no Brasil contra 312 nos EUA, 246,6 no Japão e 66,7 no Chile, em 2005, por exemplo)."

\subsubsection{Matérias primas}

A celulose é produzida a partir de troncos de árvores cultivadas, sendo as principais matérias primas o eucalipto seguido do pinus. O eucalipto é a espécie mais utilizada por apresentar ótimas características em relação ao rápido crescimento da espécie, atingindo em media 30 metros de altura em apenas sete anos. Além do crescimento rápido, o eucalipto apresenta boa proporção de fibras, celulose.

De acordo com CELULOSE \& PAPEL (2009), atualmente, no Brasil, 95\% da celulose, material fibroso contido na madeira lenhosa ou em outros tipos ou partes de vegetais concentrado após a remoção da lignina, material cimentífero dessas fibras. 
Segundo a ABTCP (1999), a celulose é um composto natural existente nos vegetais, podendo ser encontrada nas raízes, tronco, folhas, frutos e sementes, de onde é extraída. Por terem forma alongada e de pequeno diâmetro (finas), são freqüentemente chamadas "fibras". Os outros componentes encontrados, entre os principais, são a lignina, hemiceluloses, extrativos e compostos minerais, na proporção indicada na Tabela 2.2.1.1.

Tabela 2.2.1.1 - Composição das madeiras (SENAI, 1981)

\begin{tabular}{|l|r|r|r|}
\hline \multirow{2}{*}{ Componentes } & \multicolumn{3}{|c|}{ Composição Química (\%) } \\
\cline { 2 - 4 } & de & até & média \\
\hline Celulose & & & 50 \\
\hline Lignina & 15 & 35 & \\
\hline Hemiceluloses & & & 20 \\
\hline Extrativos & 3 & 10 & \\
\hline Compostos Minerais & & & 0,5 \\
\hline
\end{tabular}

Em 2007, de acordo com VITAL (2009), contabilizávamos no Brasil 6 milhões de hectares de florestas plantadas para abastecimento principalmente do setor de celulose (Tabela 2.2.1.2).

Tabela 2.2.1.2 - Florestas plantadas no Brasil em hectares de acordo com VITAL (2009).

\begin{tabular}{lrrrc}
\hline $\begin{array}{c}\text { ÁREA } \\
\text { FLORESTADA }\end{array}$ & 2005 & 2005 & \multicolumn{1}{c}{2007} & $\begin{array}{c}\text { CRESCIMENTO: } \\
\text { 2005-2007(\%) }\end{array}$ \\
\hline Eucaliptos & 3.407 .204 & 3.549 .148 & 3.751 .867 & 10,1 \\
Pinus & 1.834 .570 & 1.824 .269 & 1.808 .336 & $(1,4)$ \\
Outros & 326.176 & 370.519 & 425.194 & 30,4 \\
& & & & \\
Total & 5.567 .950 & 5.743 .936 & 5.985 .397 & 7,5 \\
\hline
\end{tabular}


O setor de celulose e papel, é o que mais consome madeira proveniente dessas florestas, de acordo com VITAL (op. cit.), como está sumarizado na Figura 2.2.1.1.

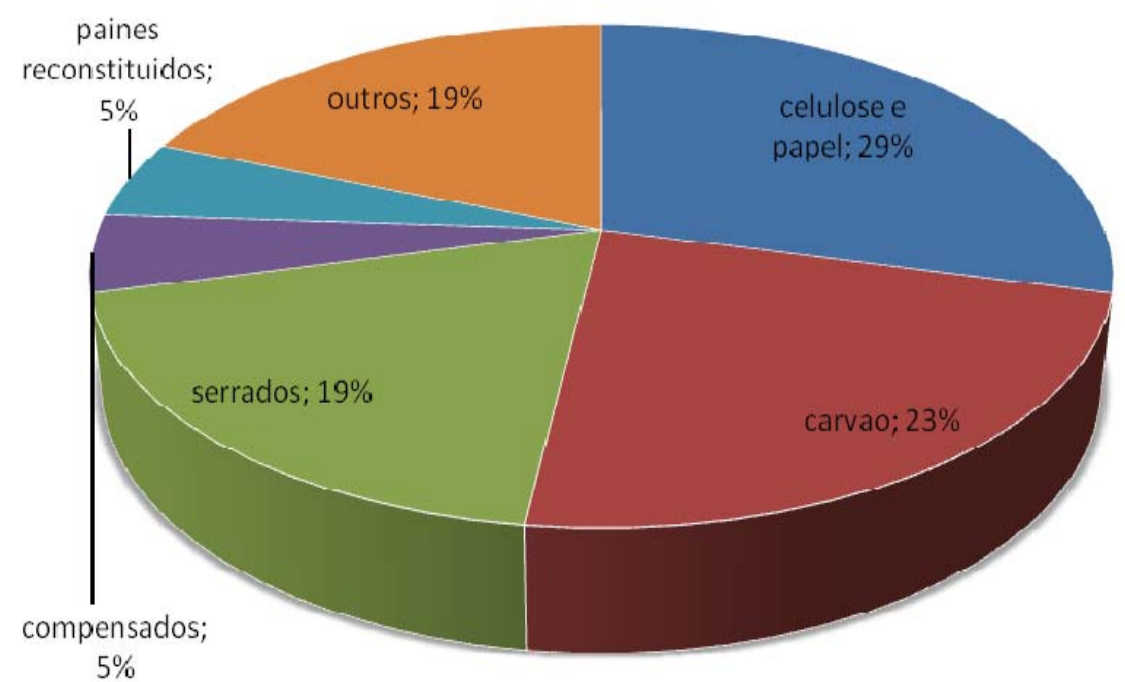

Figura 2.2.1.1 - Distribuição do consumo de madeira em toras por setor (VITAL, op. cit).

É importante citar que setor moveleiro, que inclui compensados, painéis reconstituídos e de construção civil, se beneficiam das florestas destinadas a produção de celulose, se alimentando em grande parte das mesmas, uma vez que a parte mais grossa das arvores vai para eles e a mais fina atende ao setor de lenhas para fornos e produção de carvão, enquanto que para a celulose segue diâmetros intermediários.

No Brasil o incremento médio anual da floresta por hectare plantado é da ordem de $40 \mathrm{~m}^{3} / \mathrm{ha} / \mathrm{ano}$, contra níveis inferiores a $20 \mathrm{~m} 3 / \mathrm{ha} / \mathrm{ano}$ em países europeus.Com 0 corte da espécie mais explorada se dando em ciclos mínimos de 7 anos, teremos em cada hectare a produção de $280 \mathrm{~m}^{3}$. Uma vez que para a produção de uma tonelada de celulose são consumidos cerca de $4,5 \mathrm{~m}^{3}$ de madeira ou 2,25 toneladas de madeira, para a nossa produção aos níveis de 2007/2008 da ordem de 12.000 .000 
toneladas de celulose e 9.000.000 toneladas de papel, foram necessárias a exploração de $94.500 .000 \mathrm{~m}^{3}$ de madeira, exploradas de 337.500 hectares.

O desenvolvimento florestal se dá desde a formação de mudas (Figura 2.2.1.2), passando pelo plantio e manutenção florestal, antes do corte e transporte.

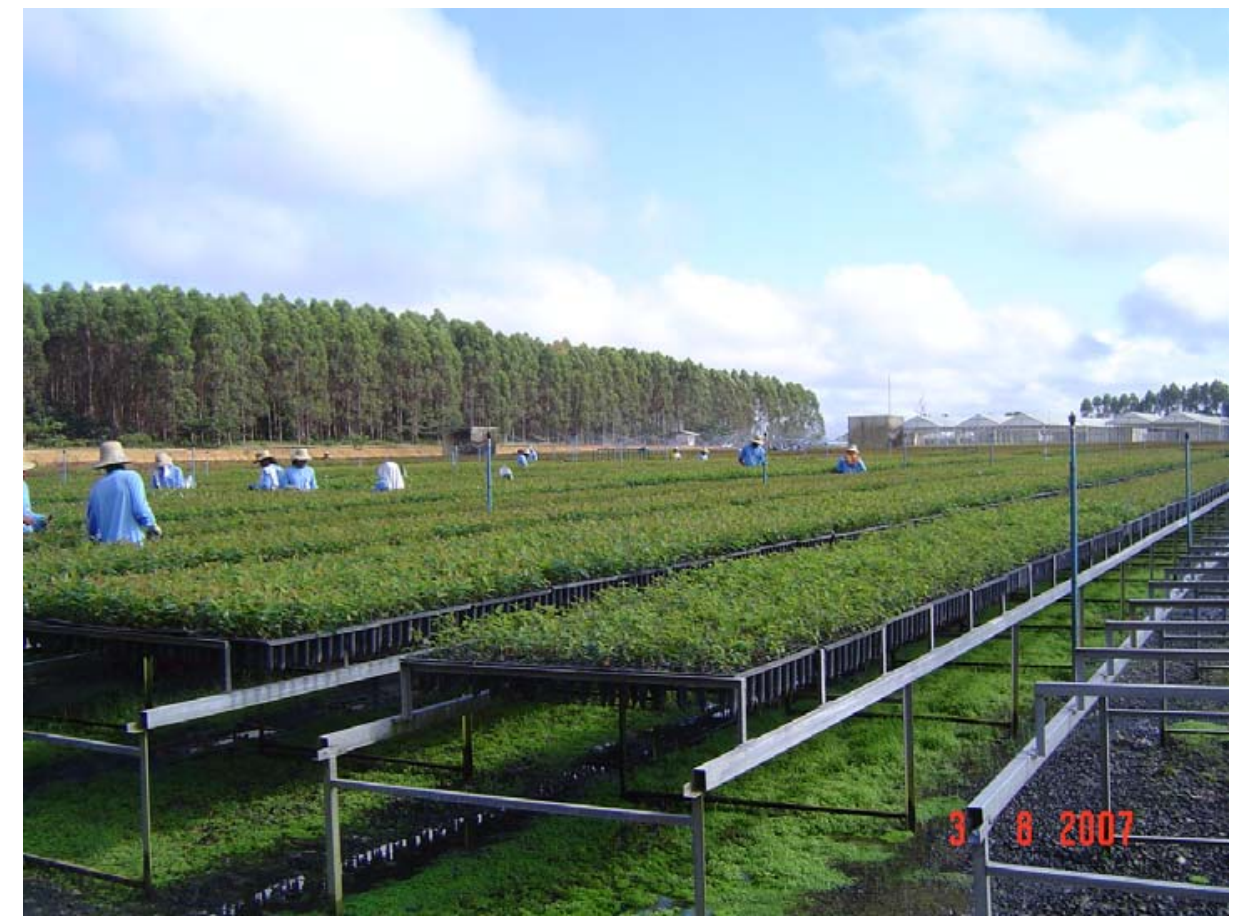

Figura 2.2.1.2 - Vista do viveiro de mudas da Jarí Celulose no Estado do Pará em imagem tomada pelo autor.

Pesquisas em desenvolvimento genético das espécies, com práticas associadas de clonagem, dentre outras, visando o melhoramento, são responsáveis para uma crescente melhoria não só nos índices de produção florestal, como também no enriquecimento de teores de celulose das espécies, melhorando rendimento e redução de efluentes indesejáveis no processo industrial discutido adiante.

O PIB Florestal, de acordo com a Bracelpa (2008), responde por $4 \%$ do PIB nacional, perfazendo um total de US\$ 21 bilhões, com destaque para três setores: celulose e papel (US\$ 7 bilhões), siderurgia a carvão vegetal (US\$ 4,2 bilhões) e madeira e móveis (US\$ 9,3 bilhões). Hoje, o setor de celulose e papel adota exclusivamente o aproveitamento de florestas plantadas (Figura 2.2.1.3). 


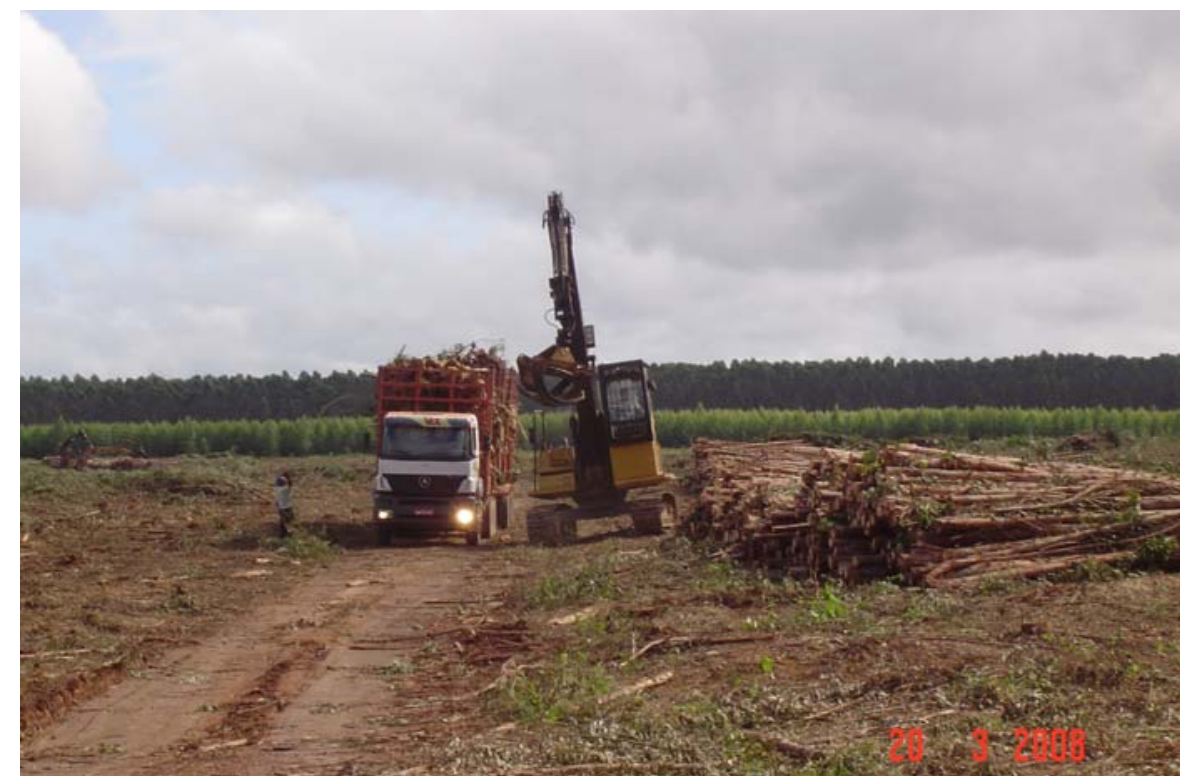

Figura 2.2.1.3 - Carregamento de toras cortadas em área de reflorestamento a ser destinada a industria de celulose regional. (arquivo do autor).

A distribuição de áreas plantadas no Brasil em 2007 pode ser vista na Figura 2.2.1.4.

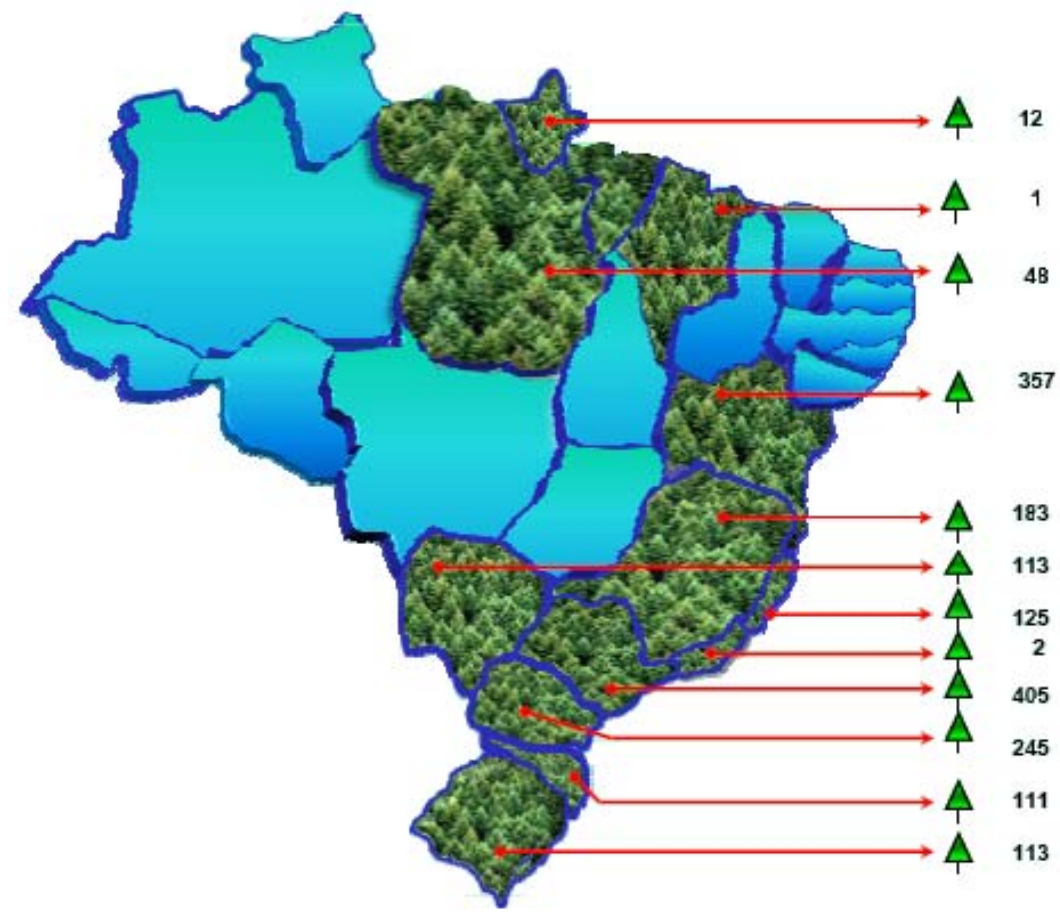

Figura 2.2.1.4 -Distribuição de áreas plantadas por estado da Federação com indicação do total de área ocupada em hectares x 1000, de acordo com Bracelpa (2008). 


\subsubsection{Processo de produção}

Para a produção ou enriquecimento da celulose é necessário converter a madeira em polpa. Nesse processo as fibras das árvores (eucalipto ou pinus) são separadas e a lignina, que pode ser comparada a uma espécie de cola que une as fibras na madeira para dar consistência, densidade, na arvore, é removida.

O processo mais tradicional em uso para essa separação da celulose da lignina é o químico, sendo mais comumente denominado de Processo Kraft, que significa "força" em alemão.

Esse processo foi comercialmente utilizado pela primeira vez na Suécia em 1885 (PIOTTO, 2003). A grande resistência dos papéis gerados foi reconhecida em relação aos processos anteriormente utilizados.

No processo Kraft, a madeira sob forma de cavacos, é tratada em vasos de pressão, denominados digestores, contendo um volume de água da ordem de $30 \mathrm{~m}^{3}$ para cada tonelada de celulose a se produzir. Os reagentes principais adicionados nos digestores são a soda cáustica (consumo especifico da ordem de 60kg/t celulose), o dióxido de cloro (18kg/t de celulose) e sulfeto de sódio, resultante da combinação de soda e enxofre. O consumo de água para produção atual de celulose nacional daria para abastecer uma cidade de 200.000 habitantes por um ano.

Os compostos químicos são utilizados no cozimento sob uma condição de pH alcalino, ajustado entre 13 e 14 no início do cozimento.

Para melhor rendimento desse processo a madeira, retirada a casca, mais pobre em celulose, é picotada em fragmentos centimetricos denominados cavacos, mais ou menos homogêneo, classificados para se ter um melhor rendimento na produção. A casca assim retirada, juntamente com galhos e outras partes mais finas da madeira descartadas na classificação dos cavacos, farão parte da biomassa que é queimada 
em caldeiras tanto para geração de energia para as fabricas quanto para gerar calor e aquecer o liquido de cozimento nos digestores.

Liberada as fibras para produção de celulose através do cozimento com os reagentes descritos anteriormente, temos no sistema o liquido restante, o licor negro (Black liquor, em inglês).

O licor negro é uma solução aquosa complexa constituída de vários compostos orgânicos (lignina, polissacarídeos, compostos resinosos e de baixa massa molar) e inorgânicos (principalmente sais), envolvendo sulfato de sódio e enxofre, estes necessários para a liberação das fibras celulósicas. Essa composição química é alterada de acordo com a espécie de madeira processada e das condições de polpeamento (GALLARDO, 1997).

O licor negro recircula na industria sendo depurado para recuperação de reagentes nobres como a soda, o que resulta com a eliminação de resíduos sólidos e efluentes líquidos.

A recuperação química numa planta de celulose e papel é parte essencial de seu projeto, atende não só a questão ambiental, mas, também, e principalmente, aspectos econômicos, uma vez que pode se reduzir muito seus custos com reagentes caros.

Os princípios da recuperação química, de acordo com o que apresenta CARDOSO (2001) são:

- Recuperação dos reagentes usados no cozimento da madeira ou outras matérias primas utilizadas na produção de celulose;

- Recuperação e utilização da energia liberada na combustão dos componentes orgânicos dissolvidos. 
O licor negro contém na sua composição, além das substâncias orgânicas extraídas da madeira durante o processo de cozimento, os componentes inorgânicos tais como $\mathrm{Na}_{2} \mathrm{CO}_{3}, \mathrm{Na}_{2} \mathrm{SO}_{4}, \mathrm{Na}_{2} \mathrm{~S}, \mathrm{Na}_{2} \mathrm{~S}_{2} \mathrm{O}_{3}, \mathrm{NaOH}, \mathrm{NaCl}$ e outros. A análise elementar do licor negro corresponde ao percentual em peso de cada elemento químico presente nos sólidos do licor. Cinco elementos estão sempre presentes: sódio (Na), enxofre $(S)$, carbono $(C)$, hidrogênio $(H)$ e oxigênio $(O)$. Na maioria dos casos, o potássio $(\mathrm{K})$ e os íons cloreto $\left(\mathrm{Cl}^{-}\right)$estão também inclusos.

O licor negro resultante da reação de cozimento, durante o processo de recuperação é encaminhado para a caldeira de recuperação (Recovery Boiler), para a evaporação parcial e, conseqüente, concentração de sólidos. A evaporação é a operação em que se concentra a solução remanescente do cozimento pela ebulição do solvente, aumentando, por conseqüência, o teor de sólidos presentes. Estes são parcialmente descarregados ao final do processo depois de atingida uma relação adotada como ideal de sólido e liquido.

Após a descarga da caldeira de recuperação o licor, mais claro, nomeado de licor verde, contendo ainda algumas impurezas e uma composição de reagentes sob formas impróprias para agir numa nova etapa de cozimento, tais como o sódio, da soda original, ora, nesse licor na forma de carbonato e não hidróxido, passa por um processo de tratamento para recuperação desse reagente, o que se dá com a adição de cal virgem a uma razão da ordem de $40 \mathrm{~kg} /$ tonelada de celulose produzida.

Os reagentes químicos recuperados farão parte do licor branco, sendo reaproveitados para novo ciclo de cozimento de cavacos nos digestores. 


\subsubsection{Resíduos sólidos gerados}

Os principais resíduos sólidos inorgânicos gerados pelas industrias de celulose são as cinzas, lama de cal, dregs e grits.

As cinzas, consideradas como resíduo inerte de acordo com a classificação ABNT (ABNT:NBR 10004/04), resultam da queima da biomassa em caldeiras, principalmente da queima de cascas da madeira utilizada para produção de celulose, apresentam uma composicao química como a mostrada na Tabela 2.2.3.1.

Tabela 2.2.3.1 - Análises de cinzas de caldeira.

\begin{tabular}{cc|c|c}
\hline Elementos & Unidades & RIPASA & JARI \\
\hline $\mathrm{CaO}$ & $\%$ & 4,82 & 4,18 \\
$\mathrm{~K}_{2} \mathrm{O}$ & $\%$ & 1,73 & 1,54 \\
$\mathrm{M} . \mathrm{O}$. & $\%$ & 4,64 & 35,16 \\
$\mathrm{Mg}$ (total) & $\%$ & 0,73 & 0,61 \\
$\mathrm{~N}$ & $\%$ & 0,26 & 0,3 \\
$\mathrm{P}_{2} \mathrm{O}_{5}$ & $\%$ & 0,71 & 0,63 \\
$\mathrm{pH}$ & - & 10,3 & 10,8 \\
$\mathrm{~S}$ & $\%$ & 0,13 & 0,46 \\
Umidade & $\%$ & 27,57 & 26,59 \\
\hline \multicolumn{4}{c|}{}
\end{tabular}

São gerados cerca de $20 \mathrm{~kg}$ de cinzas por tonelada de celulose produzida.

Os demais resíduos (dregs, grits e lama de cal) são considerados como de Classe IIA (não-inertes) devido à presença de sódio, cloro e sulfato, seja no lixiviado ou solubilizado, com concentração acima dos limites aceitáveis. Os pontos de geração desses resíduos numa planta industrial são mostrado na Figura 2.2.3.1. 


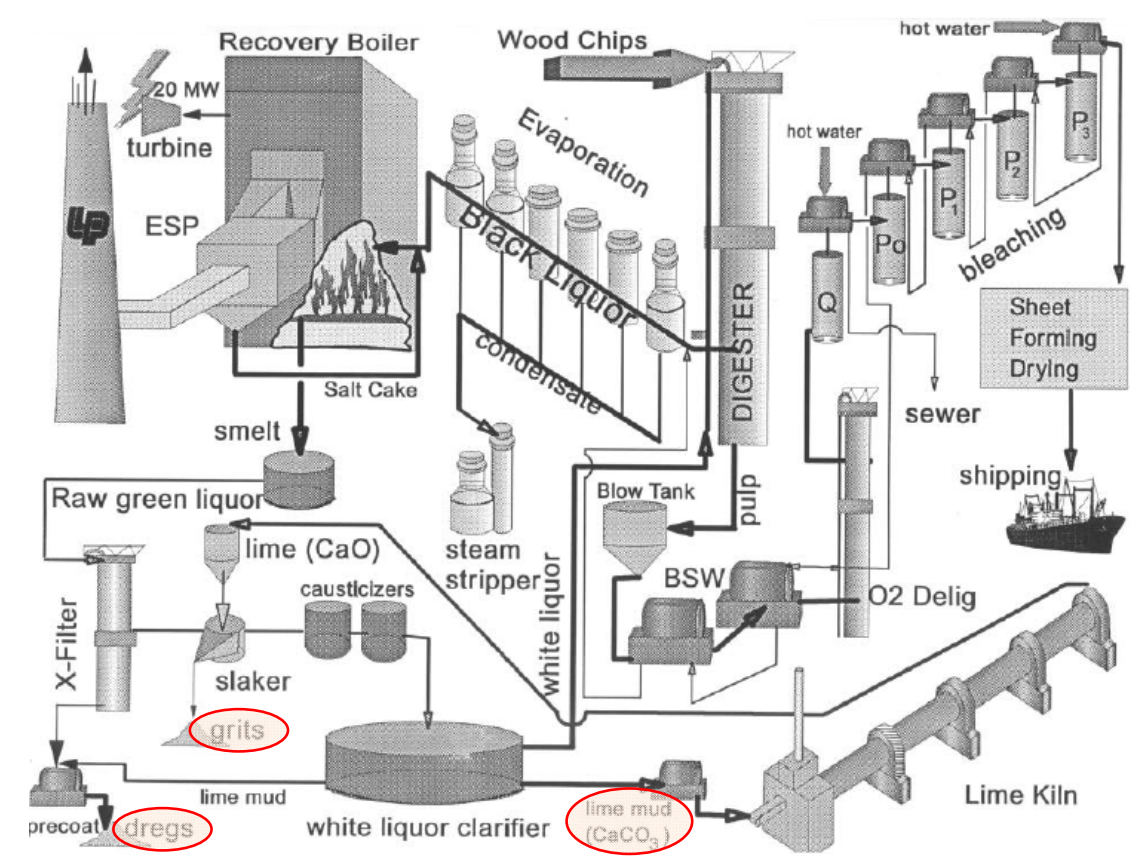

Figura 2.2.3.1. Lay-out do processo industrial de produção de celulose (pulp), incluindo a recuperação química, com destaques para os pontos de geração dos resíduos sólidos, de acordo com NORTH COAST UNIFIED (1999).

A lama de cal se forma após a reação completa da cal com o licor, quando praticamente todo o sódio foi recuperado, tendo novamente adquirido a forma de hidróxido, e a cal, oxido de cal hidratado, se transformou em carbonato de cálcio. Esse carbonato de cálcio (lama de cal) é eliminado do sistema por filtragem a vácuo. A reação básica desse processo de recuperação da soda é:

$$
\mathrm{Ca}(\mathrm{OH})_{2}+\mathrm{Na}_{2} \mathrm{CO}_{3} \leftrightarrow 2 \mathrm{NaOH}+\mathrm{CaCO}_{3}
$$

A lama de cal ( $\left.\mathrm{CaCO}_{3}\right)$ tem a maior relação de produção por tonelada de celulose produzida, na ordem de $240 \mathrm{~kg} /$ tonelada. Entretanto, na maior parte das fabricas atuais de celulose, especialmente nas mais modernas, esse material é calcinado em fornos rotativos horizontais para produção de $\mathrm{Cal}(\mathrm{CaO})$, com a eliminação do $\mathrm{CO}_{2}$, substituindo em 90\% a aquisição de Cal nova. 
A calcinação da lama de cal reduz seu descarte para níveis da ordem de 24 kg/tonelada de celulose, ficando sua geração para descarte restrita as ocorrências de paradas dos fornos (FOELKEL, 2008).

Na Tabela 2.2.3.2 são mostrados resultados de analises de lama de cal proveniente de duas empresas e de dois pontos de geração de uma delas.

\begin{tabular}{|c|c|c|c|}
\hline \multirow[b]{2}{*}{ Fonte/origem } & \multicolumn{3}{|c|}{ Lama de cal } \\
\hline & Filtro & Filtro & Pátio \\
\hline Empresa & Lwarcel & Or & sa \\
\hline Umidade & 39,2 & 30,67 & 30,23 \\
\hline $\mathrm{CaO}$ & 54,6 & 53,2 & 51,12 \\
\hline $\mathrm{K} 2 \mathrm{O}$ & 4,19 & 0,052 & 0,17 \\
\hline $\mathrm{MgO}$ & 0,17 & 0,56 & 0,42 \\
\hline $\mathrm{NaO}_{2}$ & 0,15 & 2,06 & 1,71 \\
\hline
\end{tabular}

$\mathrm{Na}$ descarga da caldeira de recuperação temos um fundido (smelt) que constitui o "dregs". O dregs é gerado na ordem de $10 \mathrm{~kg} / \mathrm{t}$ celulose e o grits na ordem de $3 \mathrm{~kg} / \mathrm{t}$.

De acordo com NURMESNIEMI ( 2005) o dregs é um material sólido, de cor escura do tipo das escórias, de onde constitui a designação do seu nome. A concentração de nutrientes no Dregs, como o $\mathrm{P}, \mathrm{Ca}, \mathrm{Na}, \mathrm{K}, \mathrm{Mg}, \mathrm{S}, \mathrm{Cu}$ e $\mathrm{Zn}$, facilmente solúveis apresentam em relação aos macros elementos uma concentração abundante de cálcio, acompanhado de magnésio e sódio.

Na reação da cal com o licor verde (Raw Green liquor), liquido resultante após separação do dregs, ocorre a precipitação do resíduo sólido denominado de "grits".

Na Tabela 2.2.3.3 constam resultados de análises de dregs e grits obtidas da literatura. 
Tabela 2.2.3.3 - Analises químicas dos resíduos obtidas na literatura.

\begin{tabular}{l|r|r|r|r}
\hline Constituintes & \multicolumn{3}{|c|}{ Dregs } & Grits \\
\hline $\mathrm{CaO}$ & 35,7 & 61,3 & 38,7 & 53,0 \\
$\mathrm{~K}_{2} \mathrm{O}$ & & 0,6 & 0,8 & 1,2 \\
$\mathrm{MgO}$ & 3,6 & 5,4 & 2,0 & 1,8 \\
$\mathrm{MnO}$ & & 0,6 & 0,7 & \\
$\mathrm{NaO}_{2}$ & 4,7 & 12,9 & 16,9 & 0,1 \\
$\mathrm{~S}$ & 1,6 & 5,6 & 3,4 & 0,7 \\
$\mathrm{Fe}_{2} \mathrm{O}_{3}$ & & 1,1 & 0,5 & \\
$\mathrm{Al}_{2} \mathrm{O}_{3}$ & & 1,3 & 0,8 & \\
$\mathrm{SiO}_{2}$ & & 3,9 & 2,2 & \\
$\mathrm{pH}$ & & 12,7 & & \\
$\mathrm{Umidade}^{\quad \text { Fontes: }}$ & LEITE (1996) & LANDIM (1994) & DESCOLLI (2002) & LEITE(1996) \\
\hline \multicolumn{4}{l}{}
\end{tabular}

Os grits, de acordo com MODOLO (2006), são impurezas como as areias, o calcário e outras escórias introduzidas pelo "make-up" de cal, oxido de cálcio, e do calcário de onde se originou. Entretanto, nas unidades produtoras de celulose dotadas de fornos para recuperação da cal, a partir da lama de cal contendo ainda um pouco de sódio, da soda não totalmente recuperada, forma-se, junto com outras impurezas fases vítreas, fundidos, que provocam a granulação da cal, ou seja, ocorre um processo de peletização da cal, formando aí também parte dos grits, que posteriormente são recolhidos e retirados do processo, se acumulando como resíduos.

Para cada tonelada de celulose produzida são gerados, no mínimo, em torno de 60 kg ou $6 \%$ de resíduos sólidos. No conjunto, projetando-se para produção nacional atual que deve estar na ordem de 13 milhões de toneladas de celulose, temos uma geração de 780.000 toneladas /ano de resíduos, sendo aproximadamente 312.000 toneladas de lama de cal, 260 mil toneladas de cinzas, 130 mil toneladas de dregs e 39 mil toneladas de grits por todo o país. 


\subsubsection{Praticas na gestão dos resíduos}

Os investimentos das empresas de celulose, como também de papel, diretamente a questões relacionadas ao meio ambiente, inserido ai o devido tratamento dos resíduos sólidos, tem sido crescente e compõem hoje mais de 50\% dos recursos aplicados em iniciativas ditas sociais.

De acordo com levantamentos da Bracelpa - Associação Brasileira de Celulose e Papel, divulgados em relatório intitulado RESPONSABILIDADE SOCIOAMBIENTAL DAS EMPRESAS DO SETOR DE CELULOSE E PAPEL (Bracelpa, 2007), dados colhidos junto a 20 empresas afiliadas indicaram que R\$ 178 milhões haviam sido investidos diretamente na área de meio ambiente em 2006, correspondendo a 55\% do total de investimentos ditos sociais nos balanços divulgados pelas empresas do setor (Figura 2.2.4.1).
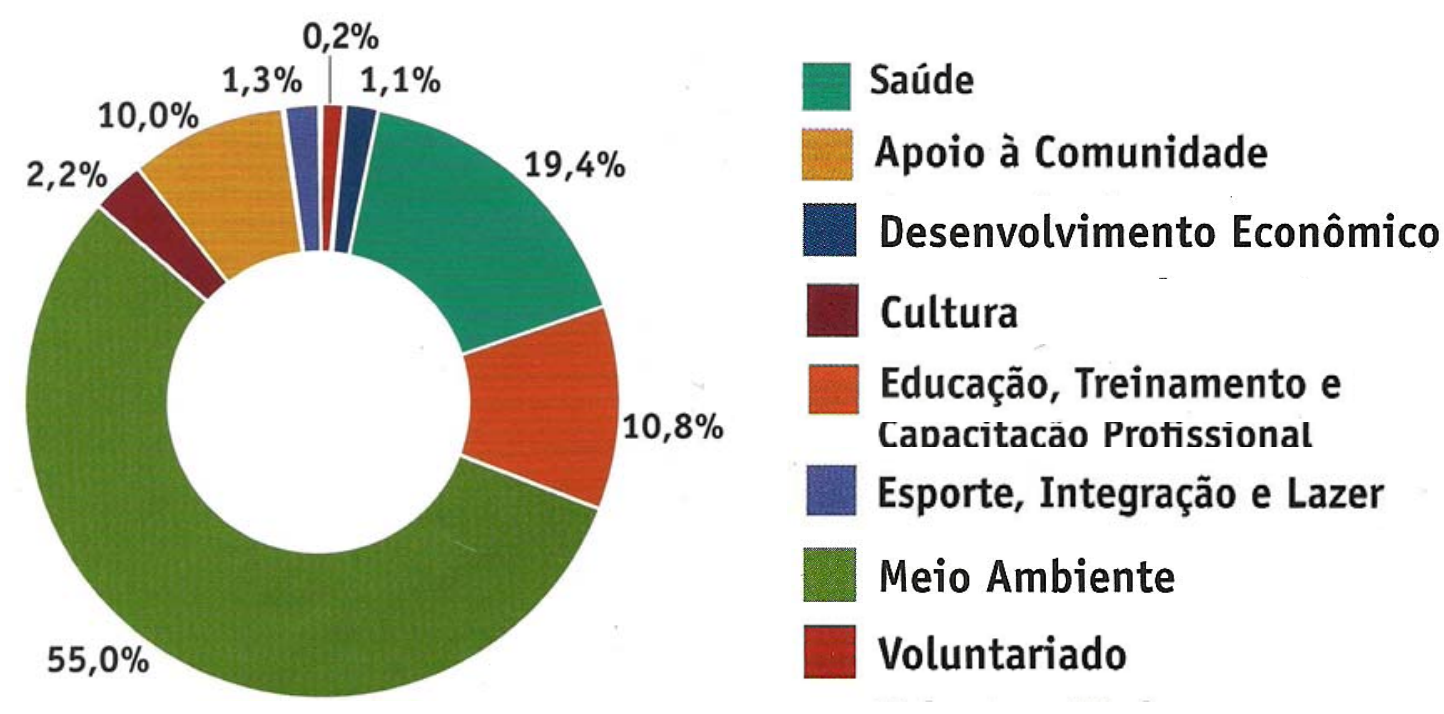

Figura 2.2.4.1 - Distribuição dos recursos aplicados em iniciativas sociais pelas empresas produtoras de celulose e papel em 2006, segundo a Bracelpa (2007)

Pela sua natureza, vinculando-se a inúmeras atividades que direta e indiretamente, podem afetar o meio ambiente e por ser voltada especialmente para a exportação, as exigências do mercado internacional para que exerça boas praticas são grandes 
e efetivas. A certificação ambiental por orgãos internacionalmente reconhecidos, através da obtenção do selo verde, é garantia exigida pelo mercado.

No aspecto relacionado a relação da atividade com a emissão atmosférica de $\mathrm{CO}_{2}$, de acordo com estudos da Bracelpa (2007), os 1,7 milhões de hectares de florestas de eucalipto, principalmente, e Pinus, absorvem em media 63 milhões de toneladas de gás todo ano; enquanto as 220 fabricas de celulose e papel emitem anualmente na ordem de 21 milhões de toneladas de $\mathrm{CO}_{2}$., desse modo concluem que as empresas do setor absorvem três vezes mais gás carbônico do que suas emissões industriais.

Em toda a verticalização do segmento,desde a formação de mudas em viveiros desenvolvidos com técnicas cada vez mais cientificas, há uma serie grande materiais que entram são processados e geram, mais ou menos, resíduos diversos, como é ilustrado na Figura 2.2.4.2.

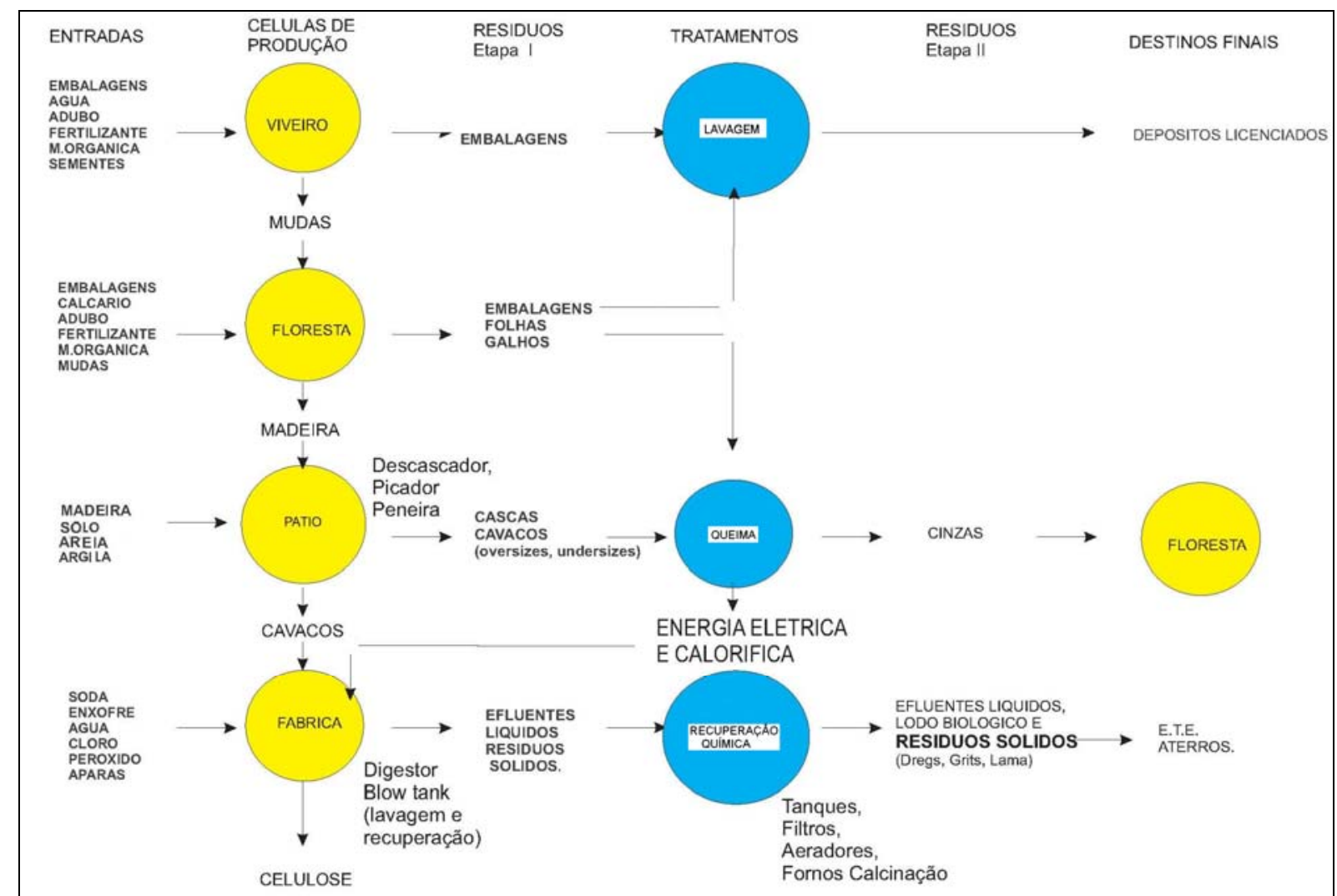

Figura 2.2.4.2 - $\quad$ Painel geral do sistema integrado de produção de celulose com indicações dos principais setores associados, seus insumos, matérias primas (inputs), processos e tratamento, e seus descartes (outputs). 
Observa-se de uma maneira em geral que as industrias de celulose vem buscando uma melhor gestão de seus resíduos, tendo como metas não somente a redução na geração dos mesmos como também encontrar aplicações diversas a simples deposição em aterro. Embora, conforme destaca PAIVA (2005), ainda hoje, na pratica, a maioria das empresas dispõem seus resíduos em aterros industriais ou urbanos próximos a suas instalações.

A disposição de resíduos em aterros se da sob custos relativamente elevados, pois, alem de se ter despesas com o tratamento, transporte e disposição dos resíduos, resta a empresa ainda a manutenção e monitoramento continuo desses depósitos por longo tempo, mesmo após a cessão da disposição ou ate mesmo a paralisação do empreendimento como um todo.

Os resíduos, materiais descartados ao longo de todo processo produtivo, seja por problemas de reação incompleta, sub-aproveitamento, não-reaproveitamento, são sempre elementos que oneram a produção, seja por desperdício de materiais ou matérias primas associados a sua geração, seja pela necessidade que se tem de removê-los do ponto de geração, transportá-lo e dispô-lo de modo adequado, o que significam custos relativos.

Até certo ponto a falta de atenção aos resíduos sólidos até recentemente, foi compreensível, conforme mencionam STEINER, C. et al.(1988), pois, segundo eles, "as praticas existentes para o controle deste problema como aterros sanitários, procedimentos de queima, eram consideradas eficientes para a resolução desta questão."

Porém, os mesmos autores continuam colocando que "estes procedimentos, muitas vezes perpetuados ao longo do tempo,atuam como paliativos momentâneos e circunstanciais, sendo questionáveis a longo prazo.". Isto, discutem esses autores, porque com o passar do tempo as áreas ocupadas pelos mesmos vão se tornando cada vez maiores e maiores as movimentações para torná-las geotecnicamente estáveis e maiores os investimentos com o seu monitoramento. 
Os resíduos sólidos, em muitos casos, podem representar um grave problema em função de diversas conseqüências negativas que podem proporcionar quando mal manejados, como contaminação de solo e água. Com a sua destinação em aterros, ocorre que a empresa acaba ganhando um passivo para toda a vida, que exige monitoramento constante de diversos elementos, como os estruturais, de estabilidade dos depósitos, e, principalmente, químico, pois se tratam de resíduos, embora não classificados como perigosos, mas não inertes, pela potencial liberação de elementos químicos que podem ser agressivos, identificados nos testes de classificação dos resíduos.

Em função de serem presumíveis acidentes decorrentes da ma disposição ou uso dos resíduos sólidos, tendo em conta os princípios da precaução e prevenção na arte do direito ambiental, no Decreto 6514/2008 (BRASIL.Decreto 6514. 2008), no seu Inciso V do Art. 62, declara-se que incorre em infração ambiental "lançar resíduos sólidos, líquidos ou gasosos ou detritos, óleos ou substâncias oleosas em desacordo com as exigências estabelecidas em leis ou atos normativos". Nesse mesmo dispositivo legal, no artigo precedente, Artigo 61, estabelece que a multa para essa infração variará de $\mathrm{R} \$ 5.000,00$ a $\mathrm{R} \$ 50.000 .000,00$, de acordo com laudo técnico elaborado pelo órgão ambiental.

As principais alternativas de disposição desses resíduos de acordo com NOLASCO (2006) estão sumarizadas na Tabela 2.2.4.1.

Tabela 2.2.4.1 - Alternativas de aproveitamento de resíduos sólidos das industrias de celulose relacionadas por NOLASCO (2006).

\begin{tabular}{|l|l|}
\hline RESIDUO & DESTINAÇÃO ALTERNATIVA \\
\hline Cascas & Fertilizante orgânico \\
\hline Dregs & Corretivo de acidez do solo \\
\hline Grits & Corretivo de acidez do solo \\
\hline Rejeitos & Produção de compósitos cimenticios \\
\hline Lama de cal & Corretivo de acidez do solo \\
\hline Lodo primário & Fertilizante orgânico \\
\hline Rejeitos celulósicos & Compósitos cimenticios (telhas, painéis) \\
\hline Cinzas & Cimento \\
\hline
\end{tabular}


A cinza apresenta um conteúdo de matéria orgânica e um pH básico que a indica para condicionamento de solo, alem de ser um supridor de elementos químicos básicos para as plantas como o cálcio e o potássio, como se pode ver na Tabela 2.2.3.1 na pagina 36 .

A grande riqueza mineral das cascas de eucalipto é o seu conteúdo em cálcio (macronutriente). Também são importantes os teores de potássio, magnésio e do micronutriente manganês. Esses minerais merecem ser administrados para a sustentabilidade futura do sítio. Exportá-los via retirada pura e simples, sem reposição significará o empobrecimento gradual do solo e prejuízos para as futuras produtividades das florestas em gerações subseqüentes (FOELKEL, 2005).

A lama de cal é um resíduo úmido que surge esporadicamente nas fábricas de celulose Kraft, uma vez que a maioria das fábricas possui fornos que a recuperam, salvo algumas exceções como a mostrada na Figura 2.2.4.3.

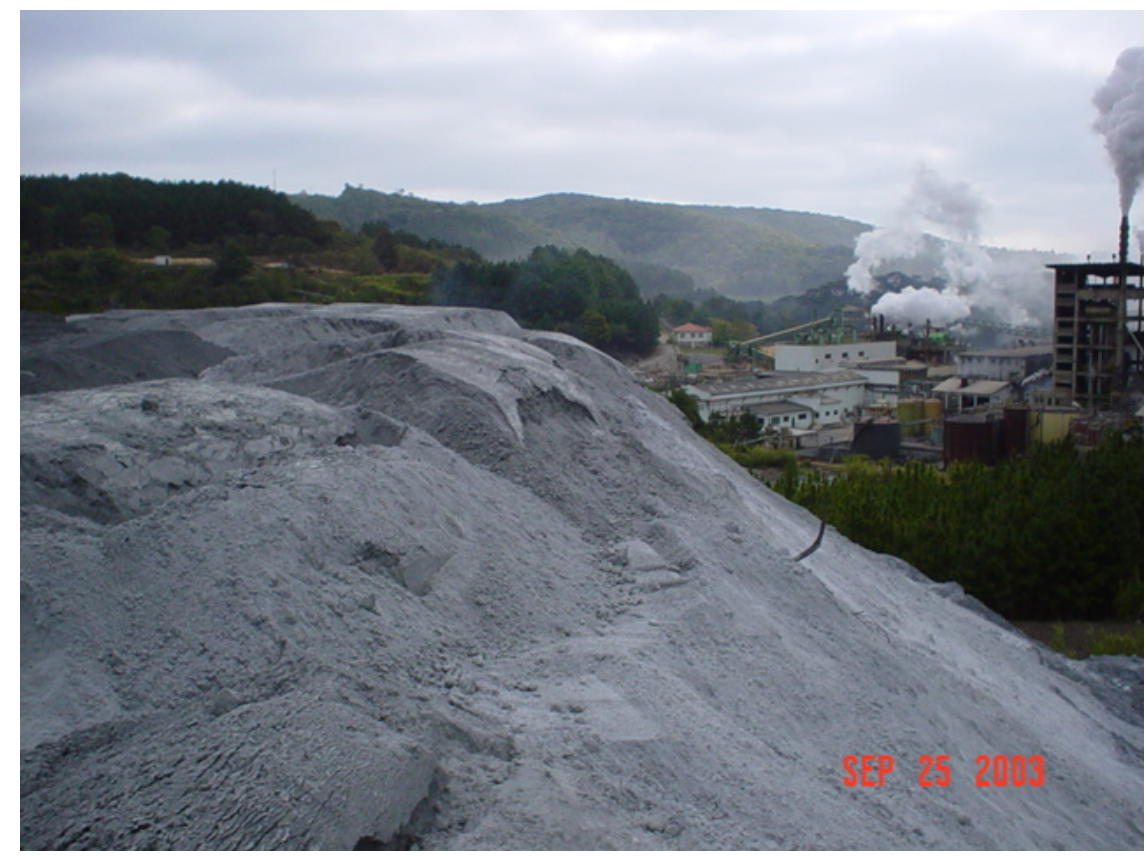

Figura 2.2.4.3 - Vista em primeiro plano de estoque de lama de cal depositada em aterro próximo a fabrica (Arquivo do autor). 
A lama de cal por apresentar uma composição química de calcário de alto $\mathrm{CaO}$, como foi mostrado na Tabela 2.2.3.2, constitui uma excelente fonte de calcário para produção de cal virgem, como também como fontes para produção de cimento ou corretivo agrícola de alto cálcio.

De acordo com artigo de ALMEIDA (2007), pela sua composição química, o dregs, principalmente pelo alto conteúdo em cálcio, e por apresentar um pH elevado, é indicado para uso como corretivo de solo e fornecedor de cálcio para o mesmo. É freqüente na bibliografia o estudo desse resíduo, tão distintos entre si como o apresentado por SANTOS (2000), que comprovou a aplicabilidade do resíduo na formulação de corantes ou colorificios a serem empregados na produção de esmaltes, vidrados, para cobertura da cerâmica de pisos e revestimentos.

Para reduzir a quantidade de grits. e melhorar a qualidade da cal virgem do forno e a filtrabilidade da lama de cal, muitos fabricantes de celulose kraft estão comprando cal virgem $(\mathrm{CaO})$ da mais alta qualidade no mercado, como fonte de reposição de cálcio no processo. Consideram que mesmo com o preço mais caro da cal virgem de mercado, os ganhos em produtividade e eficiência térmica (lama de cal mais seca na entrada do forno) são plenamente recompensados de acordo com FOELKEL (2008).

O grits, por conter valores elevados de cálcio, pode servir como corretivo da acidez de solos. Outros usos têm sido avaliados por pesquisadores diversos como em mistura com solo para aplicação em estradas florestais como divulgado por MACHADO et al (2007).

A gestão ambiental pode ser definida como o uso e proteção de recursos naturais com a aplicação de praticas ambientalmente corretas, por meio da tomada de decisão sobre a utilização da terra, água e ar. O sistema de gestão ambiental geralmente é parte integrante de um sistema de gerenciamento global e inclui uma estrutura organizacional,planejamento de atividades, responsabilidades, praticas, procedimentos, processos e recursos para desenvolver, implementar, alcançar, revisar e manter as políticas ambientais (ISO 14000 apud Habbitt \& Kamp Roelands, 2001. P 22). 
Observa-se hoje que os procedimentos gerenciais associados a gestão ambiental incluem reciclagem e reaproveitamento, disposição de resíduos e controle de ruídos e vibrações são os mais adotados. Redução do uso de matéria-prima e recursos naturais, como água empregada na formação das soluções de cozimento, tem se verificado, especialmente após 1998, marco da legislação ambiental, quando foi instituída a Lei de Crimes Ambientais (Lei 9605/1998) e as empresas se viram condicionadas a buscar níveis mais racionais de usos desses materiais, como pode bem ser visto na Figura 2.2.4.4.

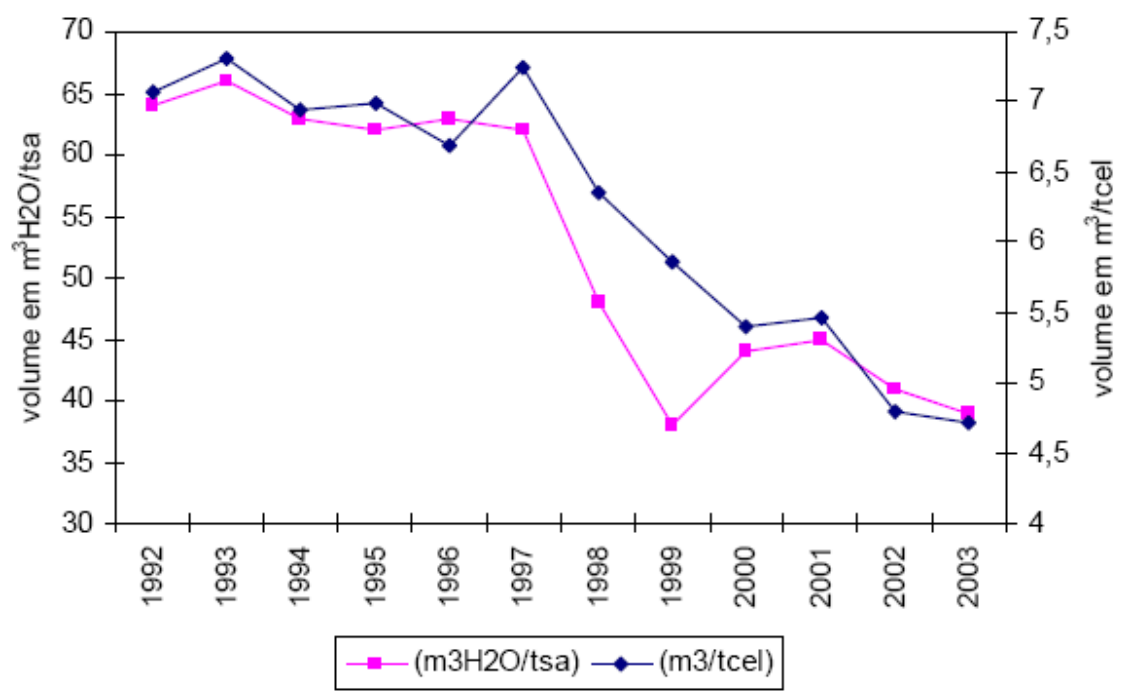

Figura 2.2.4.4 - Evolução no consumo de madeira e água pelas indústrias produtoras de celulose brasileiras, con forme discutido por GARLIPP (2005).

Os resíduos sólidos gerados diretamente dos processos industriais de fabricação de celulose e papel, embora não sejam perigosos, pela quantidade gerada, exigem um eficiente sistema de controle e gerenciamento ambiental. Um efetivo sistema de gerenciamento de resíduos sólidos deve atender aos seguintes princípios: 

a) Não gerar;
b) Redução da geração;
c) Reciclagem;
d) Tratamento;
e) Disposição final.

A não geração ou a redução da geração dos resíduos constituem as primeiras medidas a serem implementadas visando a um efetivo gerenciamento ambiental, e ambas são medidas decorrentes de alterações ou modificações nos processos de produção.

No desenvolvimento de modelos para minimização de resíduos, o atualmente consagrado é aquele que atua em três níveis, sendo o primeiro de redução na fonte, o segundo de reciclagem e o terceiro o tratamento dos resíduos (ex.: disposição em solo) propriamente dito.

A reciclagem constitui a utilização de um resíduo como matéria-prima ou como fonte de suprimento para uma utilização em outra atividade.

Os principais resíduos sólidos das fábricas de papel e de celulose são recicláveis, dependendo da avaliação técnico-economica. As cascas sujas dos pátios de madeira geralmente são devolvidas as florestas, e também através de modificações nas caldeiras a biomassa, como a substituição das grelha rotativas por outros dispositivos mais adequados, estas cascas podem ser totalmente queimadas.

De modo geral novas estratégias para a gestão de seus resíduos sólidos, pautada nos três pilares básicos da sustentabilidade ambiental: a redução, a reutilização e a reciclagem.

A redução na geração de resíduos tem também como base a redução no consumo de reagentes químicos e melhor desenvolvimento e seleção das materiais primas da floresta. A reutilização é a busca de recuperar o resíduo para trazê-lo na 
composição original e ser útil para o processo industrial, como se dá com a água tratada, com a lama de cal que é na maior parte das empresas recalcinada.

A reciclagem é a pratica alicerçada na pesquisa dos materiais visando o seu aproveitamento na composicao de novos materiais, úteis, evitando-se o seu descarte como resíduos ou rejeitos.

Um bom exemplo de gestão ambiental vem da Aracruz Celulose, de sua fábrica situada em Eldorado do Sul, no Rio Grande do Sul. Lá se tem um complexo com capacidade para tratar 200 mil toneladas/ano de resíduos com valas para fermentação anaeróbica de lodo da estação de tratamento de efluentes da planta, áreas de armazenamento para lama de cal, dregs e grits; áreas para secagem de fertilizante orgânico dentre outras edificações como pode ser visto na Figura 2.2.4.5. A área total do empreendimento é da ordem de 100 hectares.

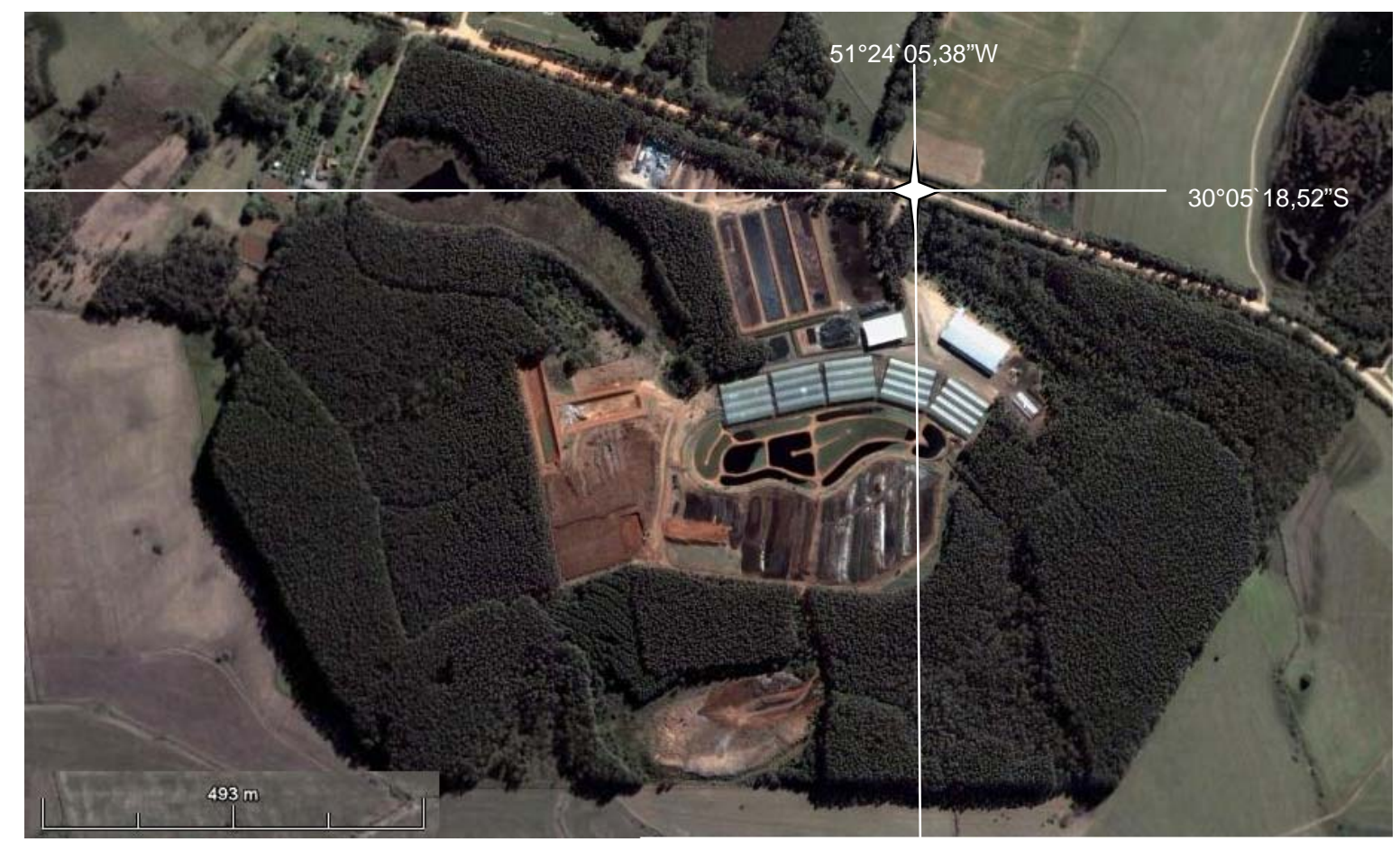

Figura 2.2.4.5 - Vista aérea das instalações da unidade que faz o tratamento de resíduos sólidos da Aracruz no RS. Imagem do Google Earth (http://earth.google.com/, acesso em 08/02/2010). 
Os resíduos, depois de reciclados, são transformados em adubo orgânico, corretivos de solo e outros produtos destinados à agricultura, horticultura e jardinagem, sendo comercializados na região metropolitana de Porto Alegre.

São gerados mensalmente nesta unidade do Rio Grande do Sul na ordem de 18.000 toneladas de resíduos sólidos. O processo de gestão implantado está a cargo de uma empresa terceirizada que tem para si as responsabilidades de monitoramento ambiental e agronômico dos resíduos em conjunto com a empresa, o manuseio interno e transporte dos resíduos sólidos, a operação da Central de Reciclagem de Resíduos, unidade de beneficiamento de fertilizantes orgânicos e corretivos de acidez de solos, comercialização e assistência técnica.

Na mesma linha de processos de tratamento do Rio Grande do Sul, se estabeleceu a estação de tratamentos de resíduos sólidos na Bahia, para processamentos dos resíduos gerados pela Veracel (Figura 2.2.4.6).

As práticas mais tradicionais de tratamento e destinação dos resíduos sólidos dentro das industrias de celulose e papel vêm da avaliação físico química individual dos elementos e procuram incorporar principalmente no ambiente físico de produção das mesmas, especialmente as áreas florestais, como se pode ver na Tabela 2.2.4.2 onde se mostra sinteticamente as principais práticas das empresas.

Em função das peculiaridades das indústrias do setor e de aspectos como o crescimento populacional, naturalmente ou induzido pelo estabelecimento dessas empresas, a conscientização quanto ao esgotamento dos recursos naturais, esgotamento da capacidade da biosfera em absorver resíduos e poluentes, desigualdades entre regiões e a globalização, essas mesmas industrias tem como necessidades uma redução cada vez maior de seu potencial de poluir, via, seja, redução na geração dos resíduos, recuperação dos mesmos e reciclagem, evitandose ter como alternativa principal a disposição em aterros. 


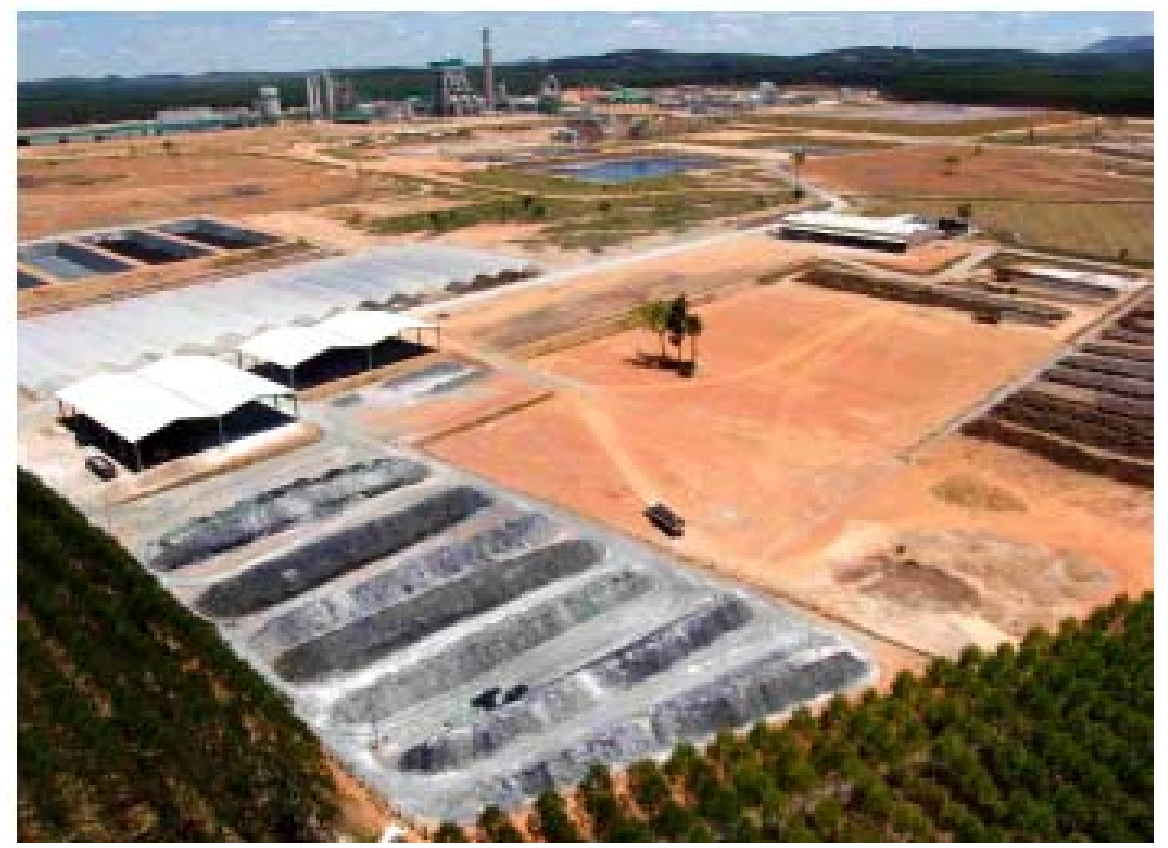

Figura 2.2.4.6 - Estação de reciclagem de resíduos sólidos da empresa Veracel, associação entre a Aracruz Celulose (50\%) e a sueco-finlandesa Stora Enso (50\%), instalada no município de Eunapolis, BA, desde 2005 (Arquivo do autor).

Tabela 2.2.4.2. Exemplos de tratamento e destinos de resíduos de algumas empresas (Bracelpa,

\begin{tabular}{|l|l|l|l|l|}
\hline 2007). \\
\hline $\begin{array}{l}\text { Resíduo } \\
\text { serragem }\end{array}$ & Origem & Tratamento & Destino & Empresas \\
\hline $\begin{array}{l}\text { Cinzas } \\
\text { (biomassa) }\end{array}$ & Caldeira & $\begin{array}{l}\text { Compostagem, } \\
\text { lodo ETE }\end{array}$ & Adubo orgânico & $\begin{array}{l}\text { Cenibra, } \\
\text { Aracruz }\end{array}$ \\
\hline Lama de cal & Caustificação & Secagem & Construção civil, fonte K, P. & Cenibra \\
\hline Dregs & Caustificação & Secagem & Colretivo de solo & $\begin{array}{l}\text { Cenibra, } \\
\text { Aracruz, } \\
\text { Iguaçu }\end{array}$ \\
\hline Grits & Caustificação & Secagem & Estabiliz. Solo (estradas) & $\begin{array}{l}\text { Cenibra, } \\
\text { Aracruz }\end{array}$ \\
\hline
\end{tabular}

Entre os principais mecanismos de tratamento de resíduos sólidos, gerados pelo processo industrial e difundidos atualmente, tem-se a utilização do processo de disposição em solo (aterros), disposição em poços, minas, cavernas, em valos de concreto ou ainda disposição em alto mar, dentre outros. A disposição mais usual do lodo das estações de tratamento de efluentes dessas indústrias, por exemplo, ainda são os aterros industriais, a um custo médio de $\mathrm{R} \$ 65,00$ a tonelada, além do valor do transporte. No entanto, pequenas empresas ainda utilizam aterros sanitários e 
lixões municipais, em desacordo com a legislação conforme é citado por ERENO (2009).

Os aterros destinados ao recebimento de resíduos sólidos constituem uma das práticas mais utilizadas no presente, em virtude de sua simplicidade de execução e de seu baixo custo; tendo como fator limitante a disponibilidade de áreas próximas aos locais de geração.

Os problemas associados a este método de disposição final incluem a possibilidade de poluição das águas superficiais e lençóis subterrâneos pela ação do chorume, alem da formação de gases nocivos e/ou odorosos. Contudo, tais problemas são minimizados através de um efetivo controle e monitoramento. Por outro lado, a tendência indeterminada de tempo de crescimento nos processos de produção e, conseqüente, geração de resíduos, acaba fazendo com que, mais cedo ou mais tarde, essas áreas utilizadas como aterro esgotem na sua capacidade de armazenagem.

A prática disseminada e comum de disposição dos resíduos - em aterros - deve ser precedida de projetos adequados, que incluam medidas de proteção ambiental tais como:

1. Localização adequada;

2. Elaboração de projeto criterioso;

3. Implantação de infra-estrutura adequada;

4. Implantação de obras de controle de poluição;

5. Adoção de regras operacionais especificas;

6. Monitoramento do lençol freático.

Os aterros ainda são formas de destinação de resíduos de tecnologia mais barata e mais conhecida. Entretanto, deve-se ter em mente também que esses aterros não servem para disposição de todos os tipos de resíduos. Os resíduos inflamáveis, reativos, oleosos, orgânico-persistentes ou que contenham líquidos livres só poderão 
ser dispostos em aterros especificamente construídos para os mesmos, com revestimentos de lençol sintético ou de concreto, alem de outros cuidados especiais.

Os fatores fundamentais para uma operação satisfatória e eficiente de um aterro industrial são a existência de vias de acesso bem pavimentadas, capazes de permitir um trafego permanente durante todo o ano.

As redes de drenagem superficial, que normalmente são construídas em forma de canaletas, devera envolver toda a área do aterro, de modo a impedir que a massa de resíduos seja atingida pelas águas pluviais da bacia circundante.

Desta forma o volume de chorume será reduzido ao mínimo, consistindo somente dos líquidos gerados pelos próprios resíduos dispostos, e pelas águas pluviais que incidem diretamente sobre a massa de resíduos. As redes e coleta do chorume geralmente são construídas em forma de "espinha de peixe", abrangendo toda a superfície do aterro. É caracterizada por um meio poroso de baixa declividade, constituindo-se de canaletas escavadas no solo, preenchidas com pedra brita e revestidas com manta geotextil.

Os líquidos percolados são conduzidos a seguir para um único local destinado a seu armazenamento e posterior tratamento, quando necessário. Este tratamento pode ser realizado em lagoas anaeróbicas ou facultativas.

O leito do aterro deve ser impermeabilizado, geralmente através de argila compactada. Deve ser mantida uma distancia mínima de 2 metros entre a camada de resíduos e o lençol freático.

A disposição dos resíduos dentro do aterro é realizada por caminhões-caçamba, e em seguida um trator de esteiras ou pa-carregadeira faz o seu espalhamento, ao mesmo tempo que vai compactando a massa de resíduos em camadas sucessivas, até a formação de uma célula compactada, que pode variar de 2 a 5 metros, sendo normalmente adotado 3 metros. 
Cada célula completada é recoberta com uma camada de terra de $20 \mathrm{~cm}$. Sobre esta nova superfície do aterro será construído um novo sistema de coleta de chorume e dos gases, interligado com o sistema da camada inferior. As células vão sendo superpostas umas sobre as anteriores, até se atingir a altura final do projeto. Finalmente, faz-se uma cobertura definitiva de terra, com 0,60 a 1,0 metro de espessura.

Tem que se levar em conta que não é só a formação do aterro com resíduos em que se deve ocupar a empresa, o responsável pelo processo, mas também do monitoramento desse deposito.

O principal objetivo de um programa de monitoramento da qualidade das águas subterrâneas em um sistema de disposição final e/ou tratamento de resíduos no solo é o de detectar, o mais rapidamente possível, a presença de poluentes provenientes de fugas não previstas no sistema desenhado.

A detecção deve acontecer o mais rapidamente possível para evitar que uma porção significativa do aqüífero seja poluída. Caso o local já esteja poluído, o monitoramento muda de enfoque, passando a tentar definir a extensão da região afetada no aqüífero e a sua taxa de migração, requerendo um maior número de poços, em geral. As principais etapas de trabalho mostram a necessidade de primeiro se caracterizar as condições de fluxo (sentido, direção, velocidade) antes de ser implementada a rede.

Esta fase de caracterização hidrogeologica e geológica previa tem por finalidade antever os caminhos preferenciais de fluxo onde irão trafegar eventuais poluentes, que deverão ser amostrados e pressupõe uma serie de trabalhos indiretos (geofísica) e diretos (sondagens) de reconhecimento.

Estabelecida a rede de monitoramento, passa-se a amostragem periódica (geralmente duas a quatro vezes por ano) para a análise laboratorial de parâmetros indicadores da fonte potencial de poluição, que devem ser relacionados criteriosamente, tanto antes como durante o período de monitoramento, escolhendo- 
se apenas os que mais indiquem os efeitos da fonte de poluição. A etapa final, ou seja, a adoção de medidas corretivas para eliminar o processo de poluição, caso existe, ou de ações para evitar o alastramento da pluma de poluição, ou, ainda, sua descontaminação, é o mais importante de todo o programa de monitoramento, sendo totalmente inútil constatar a presença de poluentes sem que se tome as medidas necessárias para mitigar seus efeitos.

Dentre as formas de disposição final os aterros industriais são os mais comumente utilizados, seguido pela aplicação nas florestas e outras formas de reciclagem. De uma forma geral, estes resíduos apresentam características propicias para um estudo mais aprofundado visando o aumento de seu reaproveitamento e/ou reciclagem, tais como a compostagem das cascas para a produção de húmus, a aplicação dos lodos das plantas de tratamento biológico como bio-fertilizantes, a utilização dos rejeitos das plantas de caustificação, que contem cálcio como corretivo de solos, a utilização dos lodos primários que contem altos teores de fibras como aglomerantes para estruturas pré-moldadas na construção civil, etc., conforme apresenta e discute TAVEIRA, L.M.B.O. (1994).

$\mathrm{Na}$ Europa, de acordo com MONTE et. al. (2009), as destinações dos resíduos sólidos das indústrias de papel tem diminuído, desde o final do século passado, na direção da destinação para aterros, se dirigindo especialmente para o uso em outras industrias (Figura 2.2.4.7). 


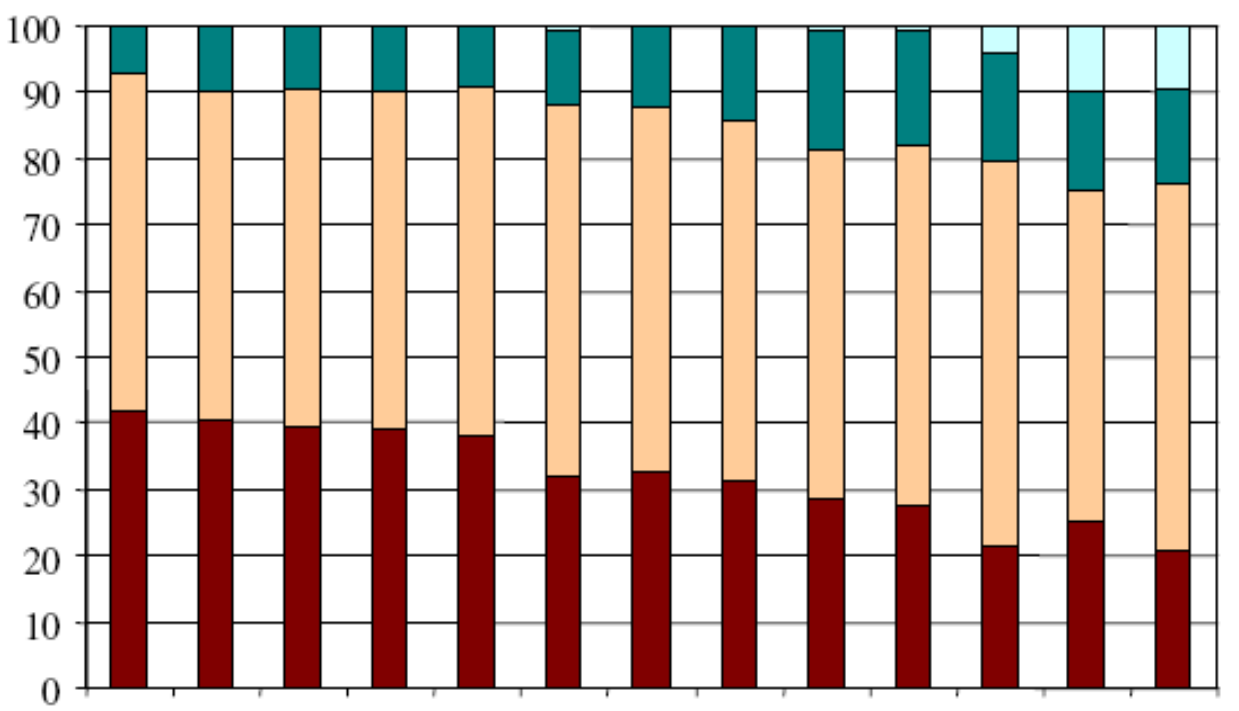
Landfills

1990199119921993199419951996199719981999200020012002

$\square$ Use in other industries $\square$ Use on land (land spreading or composting) $\square$ Energy recovery

Figura 2.2.4.7 - Evolução das destinações dos resíduos das industrias de celulose no Continente Europeu de acordo com MONTE et. al.(2009)

De modo geral, de acordo com MONTE et al (2009), as industrias de celulose e papel da Europa têm como prioridade a redução na geração de resíduos, não reduzindo a zero, sempre que possível reutilizá-lo e só no final destinar para aterros.

A principal alternativa observada na gestão do resíduo lama de cal nas industrias dos setores de celulose e papel, evitando-se sua disposição em aterros, é a de recalcinação do material. Com isso a lama passa a constituir matéria prima para a produção de cal, reduzindo assim não só a geração de resíduos, mas também, em cadeia, o consumo menor de cal virgem, conseqüentemente reduzindo a exploração de jazidas de rochas calcarias, o consumo de combustíveis e geração de $\mathrm{CO}_{2}$, dentre outros.

A lama de cal e o grits, devido ao seu elevado teor de cálcio, bem como as cinzas das caldeiras a biomassa, prestam-se também como corretivo de acidez dos solos. Entretanto por conterem elementos de certo modo agressivos em sua constituição, o que o tornam não inertes, o manuseio desses materiais deve ser revestido de cuidados especiais, especialmente para evitar contatos diretos permanentes com a pele de quem os aplica, motivo pelo qual seu licenciamento como corretivo de solo nem sempre é autorizado. 
A aplicação desses resíduos diretamente nos solos ao invés de deposição em aterros, também tornou-se uma tendência em países como o Canadá, $2^{\circ}$ produtor mundial de celulose, de acordo com ELLIOTT e MAHMOOD (2005). Esses autores mostram no gráfico da Figura 2.2.4.8 o resultado comparativo de pesquisas realizadas em 1995 e 2002.

Os lodos biológicos das plantas têm sido utilizados como biofertilizantes, sendo aplicados nas áreas florestais. Estes lodos também são utilizados, misturados ou não com cascas repicadas, na produção de húmus por meio de vermi-compostagem.

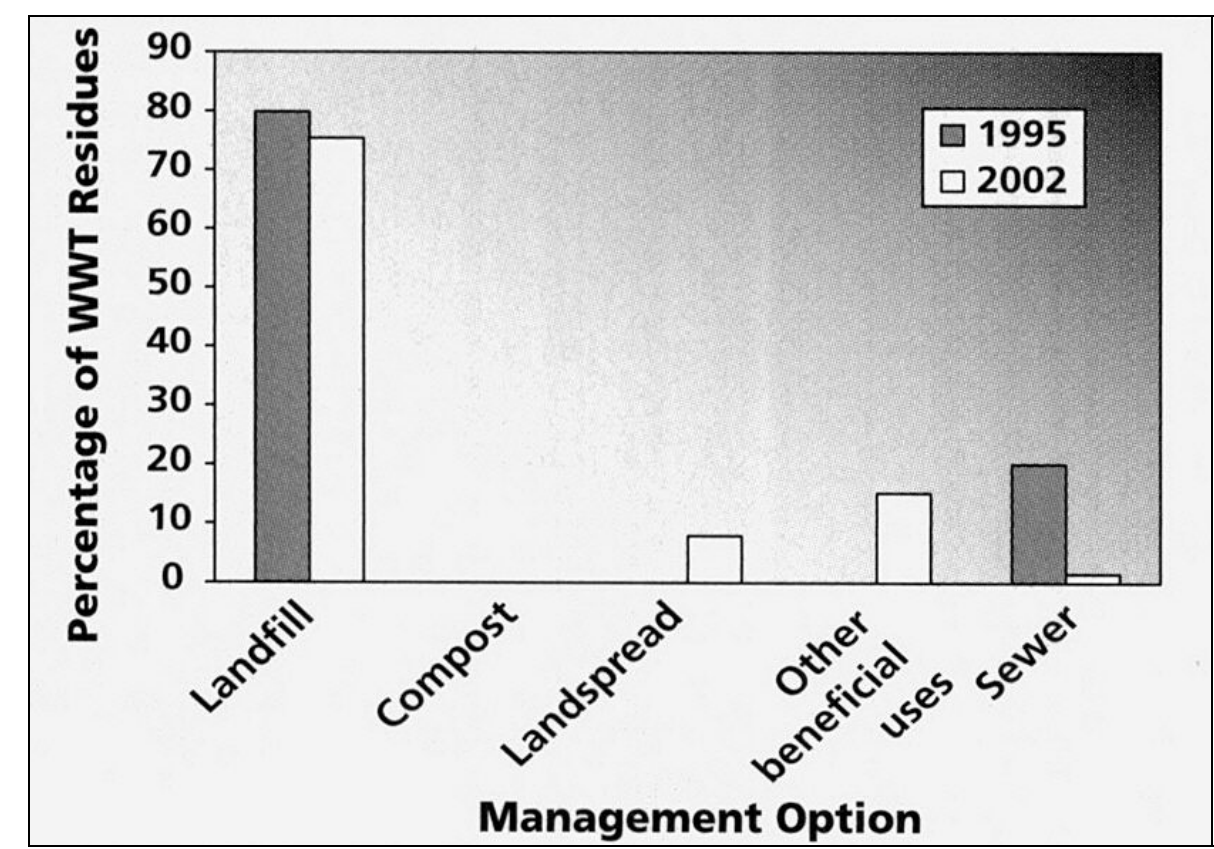

Figura 2.2.4.8 - Opções de gerenciamento de resíduos pelas industrias canadenses de celulose detectadas em pesquisas de campo, realizadas nos anos de 1995 e 2002, de acordo com ELLIOTT e MAHMOOD (2005)

A maioria dos resíduos sólidos gerados diretamente dos processos industriais, como as cascas, as cinzas, o grits, o resíduo domestico, geralmente são coletados diretamente em seus locais de geração em caçambas ou outros dispositivos semelhantes e daí são conduzidos por caminhos até ao seu local de reciclagem ou de disposição final, que na maioria dos casos são os aterros industriais. Porém, alguns outros resíduos, tais como os lodos dos sistemas de tratamento de efluentes 
e o dregs, necessitam de um tratamento preliminar de desaguamento, antes do seu envio aos locais de disposição.

Os tratamentos preliminares mais tradicionais envolvem espessamento, secagem e desidratação, estabilização e solidificação.

O objetivo primário do espessamento ou adensamento dos lodos, provenientes dos tratamentos primário e/ou secundário dos efluentes industriais ou do dregs das plantas de caustificação, é reduzir o investimento e o custo operacional das etapas subseqüentes, através da redução do volume de água contido dos mesmos

Este tratamento preliminar é feito nos espessadores, que são equipamentos que se assemelham aos decantadores convencionais, constituindo em uma etapa intermediaria entre a sua sedimentação nos decantadores até o seu posterior envio aos sistemas de desaguamento propriamente ditos, tais como os filtros a vácuo, prensas desaguadoras, etc.

Os principais processos de secagem e desidratação de resíduos foram desenvolvidos basicamente para o processamento industrial. Atualmente vem sendo utilizado para uma grande variedade de lodos industriais, com bastante sucesso desde que que esses lodos sejam constituídos por uma fase sólida filtrável.

A incineração, considerada por alguns como forma de disposição final, é um método de tratamento que se utiliza da decomposição térmica, via oxidação, com objetivo de tornar um resíduo menos volumoso, menos tóxico ou atóxico, ou ainda eliminá-lo em alguns casos.

Dentre os tipos de resíduos com maior potencial, no que diz respeito a adequabilidades ao processo de incineração, estão os resíduos orgânicos, constituídos basicamente de carbono, hidrogênio e/ou oxigênio, resíduos que contem carbono, hidrogênio, cloro com teor a 30\% em peso e/ou oxigênio e resíduos que apresentem seu poder calorífico inferior maior que $4.700 \mathrm{kcal} / \mathrm{kg}$. 


\subsection{INDÚSTRIA CERÂMICA}

O temo cerâmico vem do termo grego "keramiké" que significa material queimado. No caso dos materiais cerâmicos da classe denominada "Cerâmica Vermelha ou Estrutural", a indústria gera seus produtos a partir da queima de materiais argilosos a temperaturas na faixa de 800 a $1000^{\circ} \mathrm{C}$. Estima-se o consumo anual superior a 100 milhões de toneladas de argila por essas indústrias. Via de regra, essas argilas são exploradas de jazidas em terrenos baixos, mangues e várzeas.

O segmento da Cerâmica Vermelha é responsável pela produção de telhas, blocos e tijolos para uso na construção civil. De acordo com a ANICER (2010), existe aproximadamente uma indústria cerâmica vermelha para cada município brasileiro. Dados de produção e consumo de matéria prima divulgados por essa instituição estão resumidos na Tabela 2.3.1.

Tabela 2.3.1 - Produtos, produções e consumo de matéria prima pelas indústrias de cerâmica vermelha no Brasil de acordo com ANICER (2010).

\begin{tabular}{|c|c|c|c|c|}
\hline & \multirow{3}{*}{$\begin{array}{l}\text { prod. mês } \\
\text { ( } n^{\circ} \text { peças) }\end{array}$} & \multirow{3}{*}{$\begin{array}{c}\text { consumo matéria-prima } \\
\text { (t/mês) }\end{array}$} \\
\hline & & & & \\
\hline produto & $\mathrm{n}^{\circ}$ empresas & \% setor & & \\
\hline Blocos/Tijolos & 3600 & 63 & 4.000 .000 .000 & 7.800 .000 \\
\hline Telhas & 1900 & 36 & 1.300 .000 .000 & 2.500 .000 \\
\hline Tubos & 12 & 1 & - & - \\
\hline
\end{tabular}

\subsubsection{Matérias primas}

A matéria prima básica da industria de cerâmica vermelha são as argilas comuns, preferencialmente as que apresentam um comportamento plástico quando umidecidas e se tornam facilmente moldáveis para a produção de peças cerâmicas. Além disso, essas matérias primas devem conferir as peças cerâmicas moldadas, após queima, propriedades físicas adequadas para seu uso final no setor de 
construção, tais como resistência mecânica, níveis adequados de porosidade e absorção de água, dentre outras.

Esse material argiloso, ou "barro", agrupa uma enorme variedade de minerais de argila, ou argilominerais, com todo tipo de impurezas, diversos minerais, óxidos metálicos, matéria orgânica, fazendo com que apresentem características bastante distintas quer estejam crus ou cozidos (queimados). Os constituintes individuais das jazidas de argila apresentam como características comum uma granulometria bastante fina, predominantemente inferior a 0,044 $\mathrm{mm}(44 \mu \mathrm{m})$.

De acordo com SOUZA SANTOS (1975) as argilas para cerâmica vermelha, "na natureza, são pretas, vermelhas, marrons ou amarelas; ou esverdeadas; essas argilas apresentam cor vermelha a $950^{\circ} \mathrm{C}$ e cor marrom ou preta a $1.250^{\circ} \mathrm{C} . "$

As argilas são encontradas em jazimentos naturais predominantemente ocupando laterais de redes de drenagem e várzeas, sendo ditos depósitos aluvionares. Derivam da alteração de rochas, transportadas, segregadas durante o transporte e deposição, especialmente por meio fluvial, através de rios e lagos. Situam-se normalmente em várzeas, planícies laterais de rios, zonas estas consideradas de proteção ambiental ou área de preservação permanente de acordo com o Código Florestal (BRASIL. Lei 4771/1965).

Pela legislação ambiental, a exploração de áreas dessa natureza só pode ser autorizada para o exercício de atividades de utilidade publica ou de interesse social. Por ter sido considerada uma atividade de interesse social, de acordo com a Resolução Conama no 369 de 28 de março de 2006 (BRASIL, 2006), a extração de argila para construção civil se tornou passível de licenciamento ou autorização ambiental, como pode se ler do texto destacado deste instrumento normativo, reproduzido a seguir. 


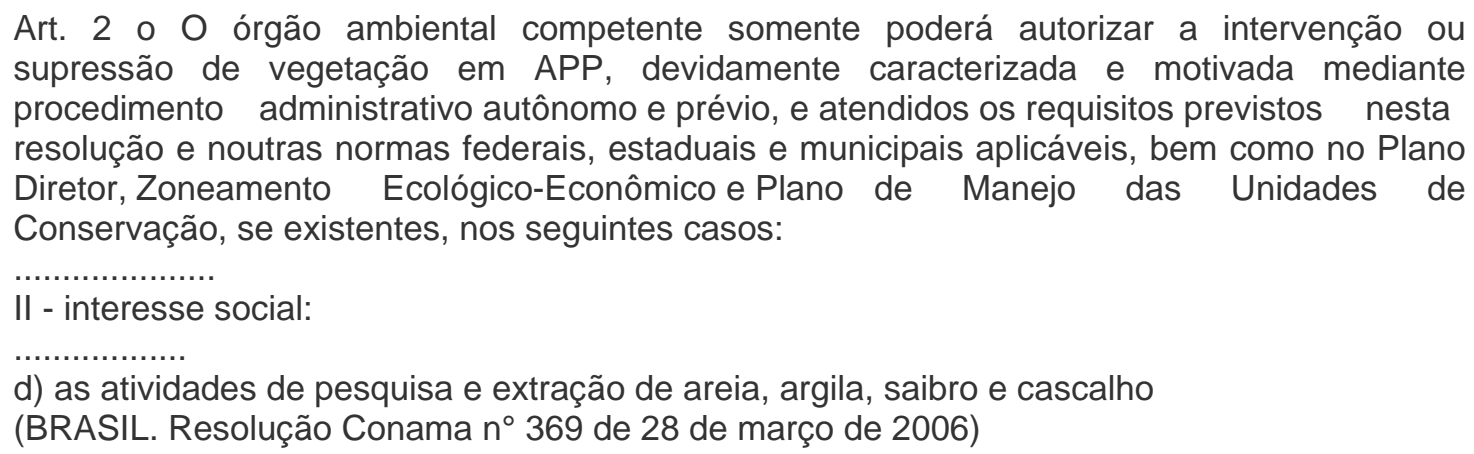

Por serem estas matérias primas bens minerais não renováveis e ocorrerem, via de regra, sob áreas de interesse a preservação permanente por questões principalmente ligadas a preservação da biota, o aproveitamento dessas jazidas será sempre bastante controlado e evitada ao maximo sua autorização pelos órgãos estatais, razão pela qual a substituição desses materiais naturais por resíduos é mais do que recomendável, sendo quase uma condição necessária.

\subsubsection{Processo de produção}

O processo de produção de peças cerâmicas estruturais vermelhas consiste na homogeneização das matérias primas, sua moldagem no formato que se deseja para as peças a serem produzidas e a queima dessas peças, empilhadas, em fornos a lenha ou gás por períodos variáveis, dependendo das características dos materiais e de suas resistências observadas, a temperaturas, geralmente, entre 800 e $1100^{\circ} \mathrm{C}$.

\subsubsection{Incorporação de resíduos em massas cerâmicas}

A tendência de se buscar alternativas de uso para os resíduos, evitando-se o seu descarte puro e simples, vem mobilizando ao longo dos últimos anos federações industriais em todo país. Prova disso podemos ter acessando sítios na internet das 
principais entidades corporativas como a FIERGS - Federação das Indústrias do Estado do Rio Grande do Sul (http://www.bancossociaisrs.org.br/bancoderesiduos/), FIEB - Federação das Indústrias do Estado da Bahia (http://200.223.40.100/bolsa/bolsa.nsf/exibicao?OpenForm\&chv=apr projeto), FIESP - Federação das Indústrias do Estado de São Paulo (http://apps.fiesp.com.br/bolsaresiduos/), isto é, em todas as regiões brasileiras o problema dos resíduos e de se dar solução ambientalmente correta para eles é sentido e se empenham para o encontro de alternativas entre membros da própria congregação.

Via de regra as melhores alternativas de disposição de resíduos, em substituição ao descarte puro e simples em aterros, se dirigem às indústrias que nos seus processos produtivos empregam métodos de calcinação e homogeneização de compostos, como são as industrias cerâmicas de modo geral.

Nos últimos eventos do setor, especialmente nos congressos técnicos anuais promovidos pela ABC - Associação Brasileira Cerâmica, são cada vez mais numerosos os trabalhos envolvendo avaliações de resultados de incorporação de resíduos de naturezas diversas. Como exemplo, somente em um desses eventos, ocorrido em Salvador (BA), em 2007, foram apresentados trabalhos de avaliações de introdução de resíduos em cerâmica vermelha, tão diversos como lama de alto forno, apresentado por VIEIRA et. al. (2007), resíduos de tratamento de água, apresentado por MARGEM et al. (2007), escória de alto forno e vidro reciclado, por REIS et. al. (2007), lodo de estação de tratamento de esgotos domiciliares por KOZIEVITCH et al. (2007) e resíduo sólido proveniente do polimento de grês porcelanato (ANDRADE e PASKOCIMAS, 2007). 


\section{MATERIAIS E MÉTODOS}

Os materiais foram obtidos de uma mesma região geográfica, sendo rejeitos de processo industrial e uma matéria-prima natural empregada na produção de peças cerâmicas para obras de alvenaria (tijolos e blocos).

Os materiais foram caracterizados em suas propriedades tanto separadamente como em misturas (argila + resíduos), sendo que as amostras preparadas foram analisadas tanto "in natura" como após queima em temperaturas de referência industrial.

\subsection{MATERIAIS}

Os residuos solidos dregs e grits conjuntamente com argila explorada na mesma região da industria de celulose, geradora desses resíduos, foram os elementos base dos trabalhos desenvolvidos.

\subsubsection{Resíduos sólidos}

Foram estudados dois resíduos sólidos gerados simultaneamente durante os estágios de recuperação química na industria de celulose da Jari Celulose S.A., localizada às margens do rio Jarí, na divisa dos Estados do Pará e do Amapá (Figura 3.1.1.1), fornecidos gentilmente pela empresa.

Esta fábrica de celulose é a unidade industrial do setor que se encontra mais isolada, dentre as demais, e mais distante de centros poli-industriais conforme mostrado na Figura 2.2.3 no capitulo anterior. Portanto, os resíduos ali gerados são de difíceis 
destinações pela falta de um parque industrial diferenciado onde os materiais poderiam ser introduzidos.

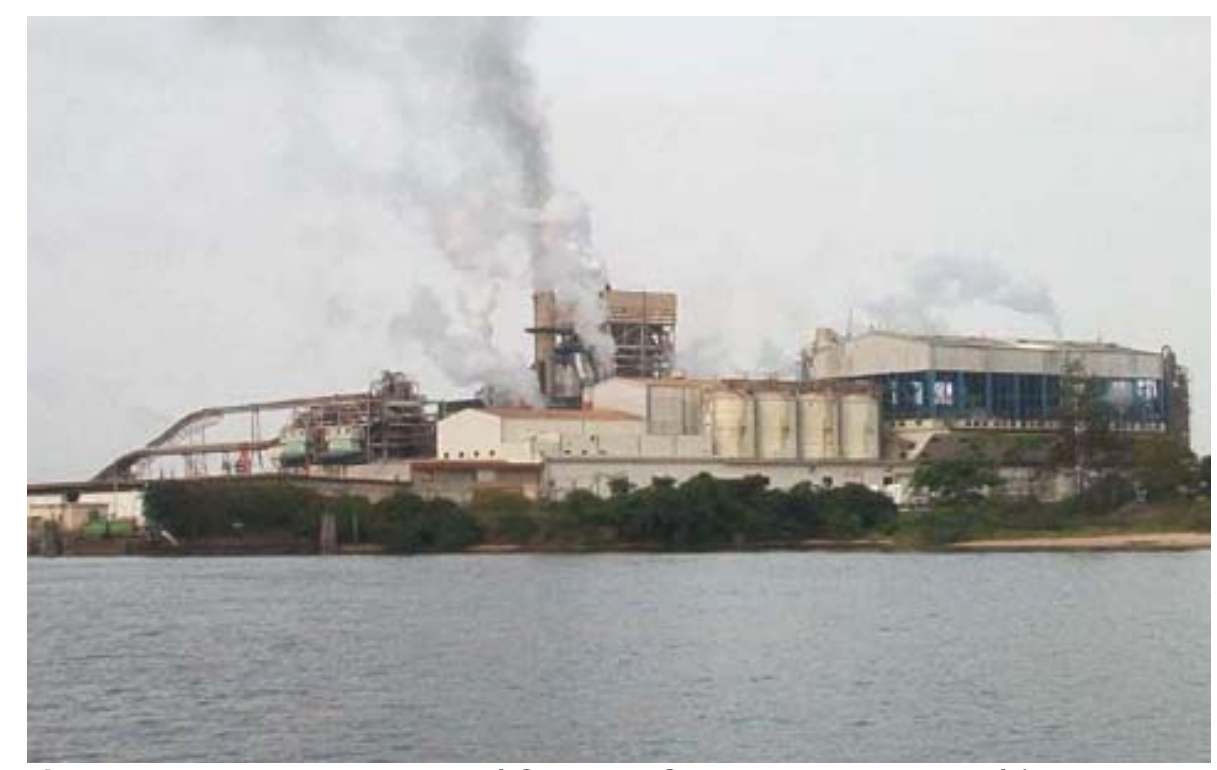

Figura 3.1.1.1 - Vista da Jarí Celulose S.A. a partir do rio Jarí (Arquivo do autor).

Considerando a destinação dos resíduos em aterros, tem-se ainda a limitação desta fábrica situar-se na região amazônica, onde, por força do Código Florestal Brasileiro (BRASIL. Lei $n^{\circ}$ 4771/65) e suas regulamentações, 80\% das áreas das propriedades rurais devem ser constituídas por vegetação nativa, restringindo ainda mais os espaços físicos adequados para as destinações de resíduos dessa natureza.

Os resíduos avaliados foram o "dregs" e o "grits". A coleta dos mesmos foi feita diretamente ao lado da planta industrial, nos pontos de descarga (Figura 3.1.1.2). A geração na oportunidade da coleta era da ordem de 12 toneladas diárias, sendo que destes, 9 toneladas eram de dregs e 3 toneladas eram de grits (informação pessoal) ${ }^{1}$.

1

Douglas A. Hartmann. Mensagem recebida por alcídio.ribeiro@poli.usp.br em 12/06/2008. 


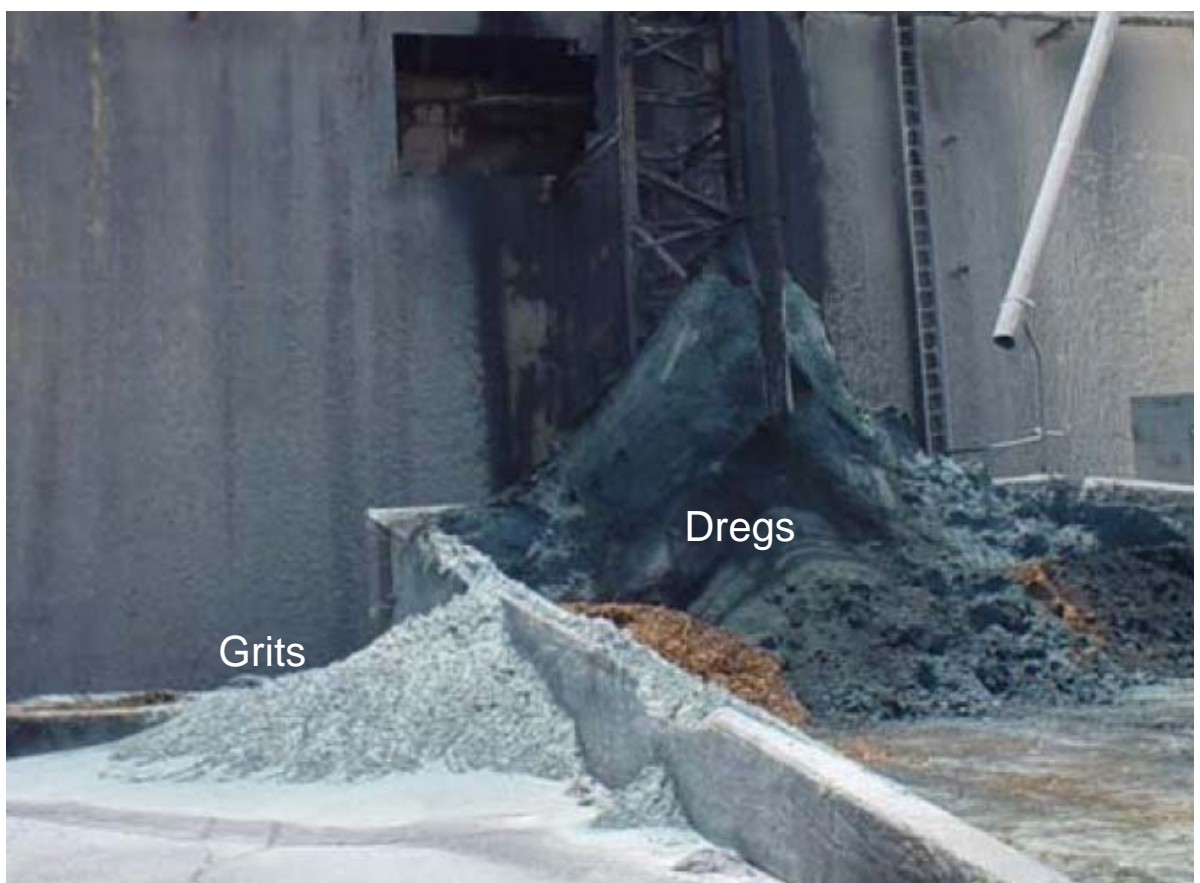

Figura 3.1.1.2 - Local de descarga de dregs e grits na planta da Jarí Celulose S.A., fotografado pelo autor.

O procedimento de amostragem obedeceu a norma da ABNT (ABNT NBR 10007). Foram coletadas amostras compostas de cada um dos resíduos, sendo tomada para cada resíduo amostras em cinco pontos das pilhas observada na Figura 3.1.1.2, sendo um na parte superior, outros na parte interna e inferior da pilha com amostrador de grãos de aço inoxidável, conforme mostrado na Figura 3.1.1.3.

As amostras coletadas de cada resíduo foram dispostas sobre lonas plásticas, aberta em forma de um quadrado, sendo os mesmos, individualmente, homogeneizados, misturados, por revolvimento, ora com o erguimento desta lona por um de seus vértices, ora pelo vértice oposto, em oito operações articuladas. 


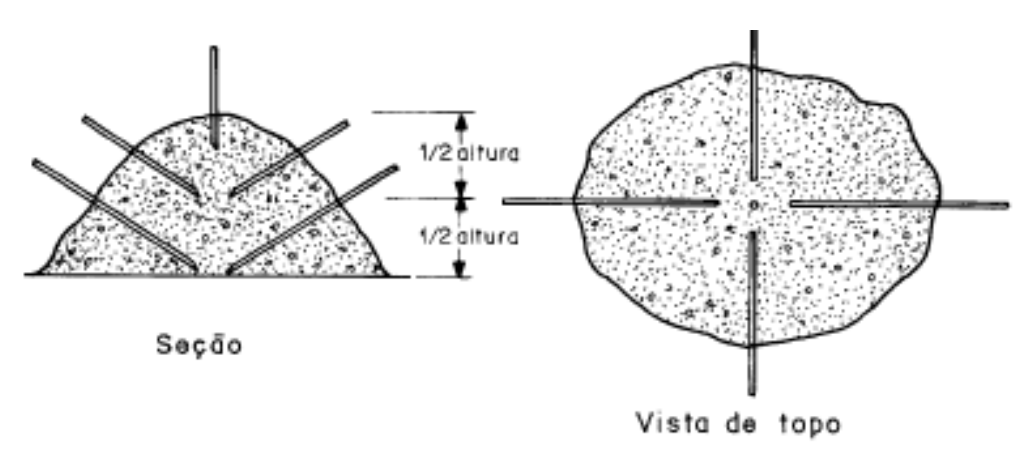

Figura 3.1.1.3 - Desenho esquemático demonstrando o arranjo da tomada de amostras das pilhas de resíduos.

Após a mistura comentada no parágrafo anterior, as amostras foram colocadas em sacos plásticos de polietileno resistente, lacrados termicamente e etiquetados, sendo em seguida despachados, via malote, para o laboratório da LMPSol em São Paulo. As amostras pesaram em torno de $5 \mathrm{~kg}$ cada.

Na Jarí, à época da visita à área, esses resíduos vinham sendo depositados na forma de aterros controlados em área próxima à fábrica, licenciada ambientalmente.

\subsubsection{Argila}

A argila, cuja jazida situa-se a margem esquerda rio Jari, foi fornecida pelo empreendedor local como uma amostra representativa do material empregado para produção cerâmica em seu empreendimento. A área localiza-se no município de Laranjal do Jarí, no Estado do Amapá. Na Figura 3.1.2.1 temos o registro do momento da coleta da amostra utilizada para os estudos.

Esta jazida de argila encontra-se dentro do contexto de depósitos sedimentares do Quaternário, isto é, recentes, do período atual, formados pela dinâmica ativa de 
transporte e sedimentação dos materiais trazidos em suspensão pelos rios e córregos que formam a bacia hidrográfica regional.

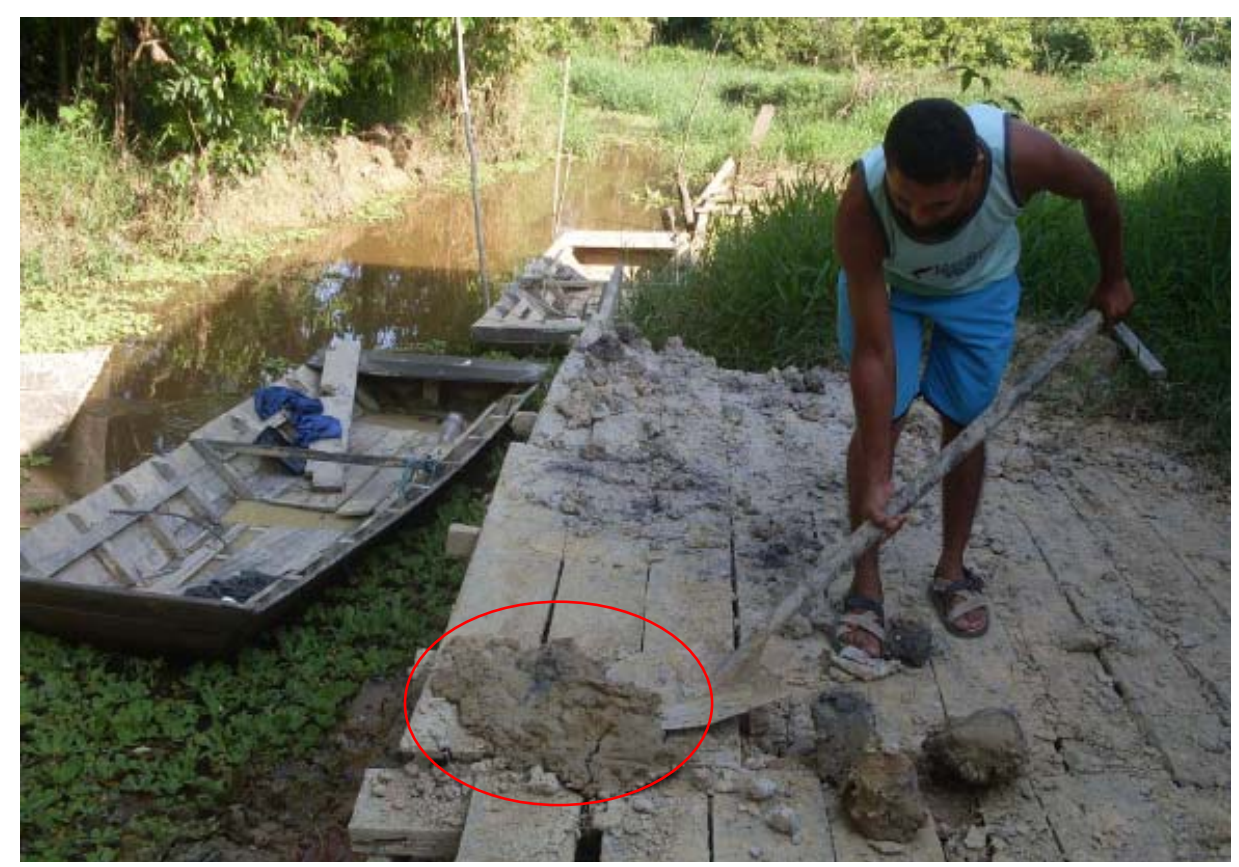

Figura 3.1.2.1 - Flagrante da coleta de argila pelo produtor cerâmico local, tomado pelo autor.

Esse ambiente de deposição é do tipo fluvial anastomosado, isto é, formado por uma associação de canais por onde correm as águas das diversas linhas de drenagem, depositando, via de regra, areia no fundo do traçado de seus leitos e nas margens os materiais mais finos, argilas e siltes. Isso ocorre nos períodos em que as águas, nas épocas das chuvas e enchentes, cobrem as planícies, planícies de inundação, deixando, em seu retorno para o leito original, quando cessam substancialmente as contribuições mais severas de chuvas sazonais, os depósitos de materiais mais finos, que eram mantidos em suspensão enquanto essas areas encontravam-se alagadas. Esses finos formam as camadas e lentes de argilas exploradas para a produção de tijolos. A seguir apresenta-se Mapa Geológico Regional com indicação da situação da jazida de argila e da fábrica da Jarí Celulose (Figura 3.1.2.2). 


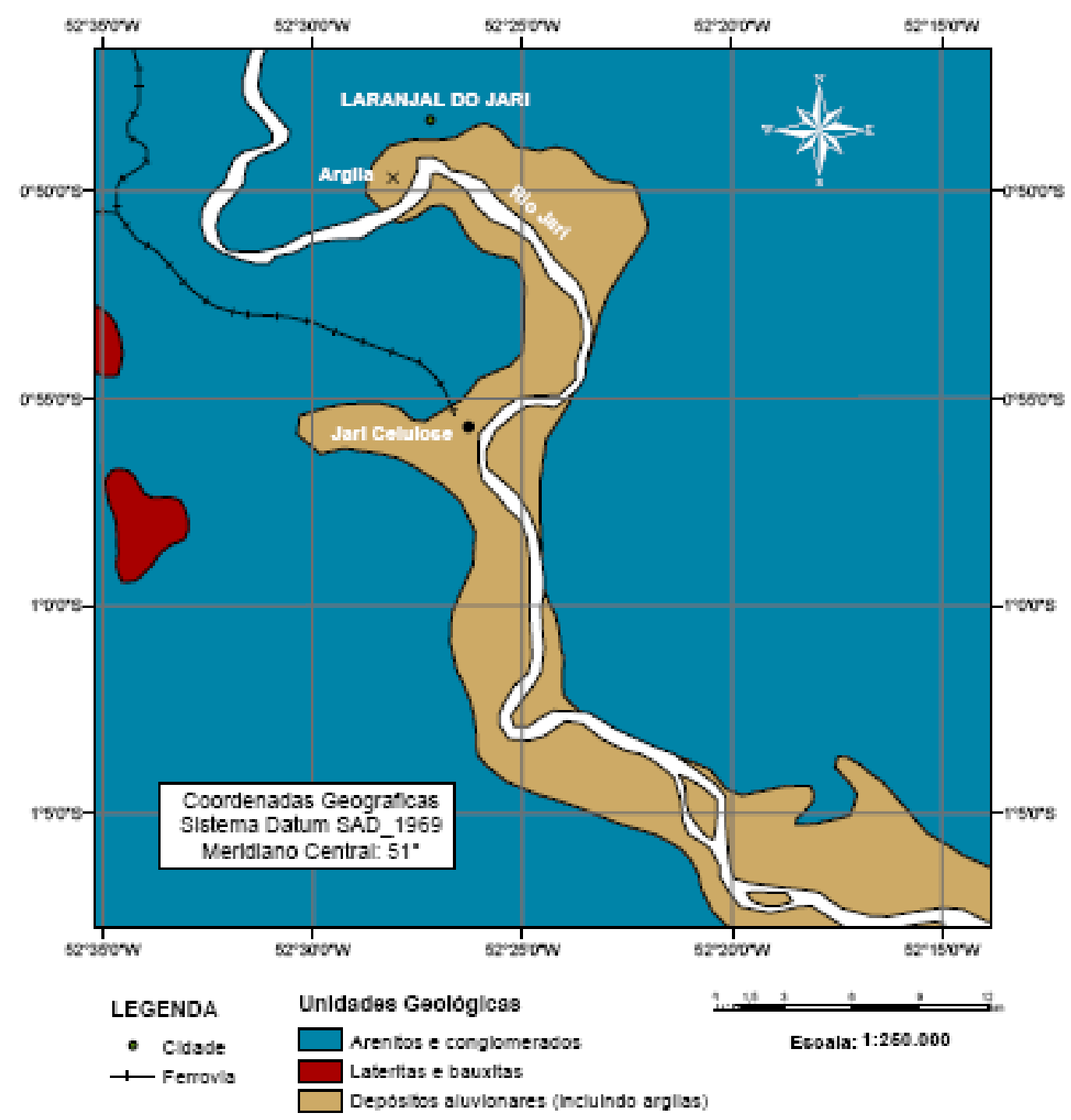

Figura 3.1.2.2 - Mapa geológico regional com indicação dos locais onde são gerados os resíduos e é extraída argila para produção cerâmica.

A unidade de produção cerâmica local que utiliza a argila coletada para produção de tijolos, como se pode ver na Figura 3.1.2.3, é bastante rústica. A argila alimenta uma maromba (extrusora) onde a pasta formada é homogeneizada, sendo coletada por uma rosca sem fim contra uma matriz (orifícios) que da forma a peça, cortada na sequencia em dimensões do mercado (Figura 3.1.2.4). A peça assim conformada 
deve depois ser secada e posteriormente queimada a temperaturas moderadamente elevadas, geralmente acima de $750^{\circ} \mathrm{C}$.

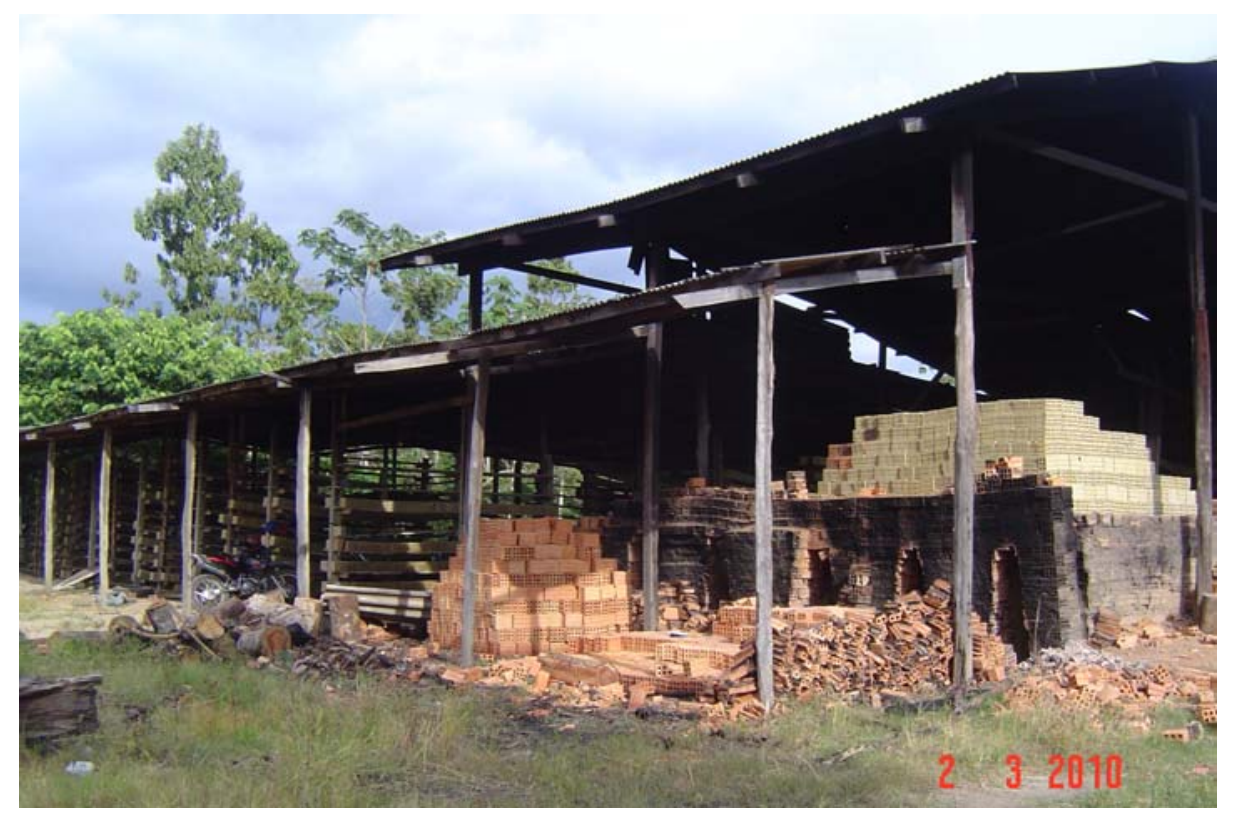

Figura 3.1.2.3 - Olaria onde foram colhidas amostras de argila para os estudos.

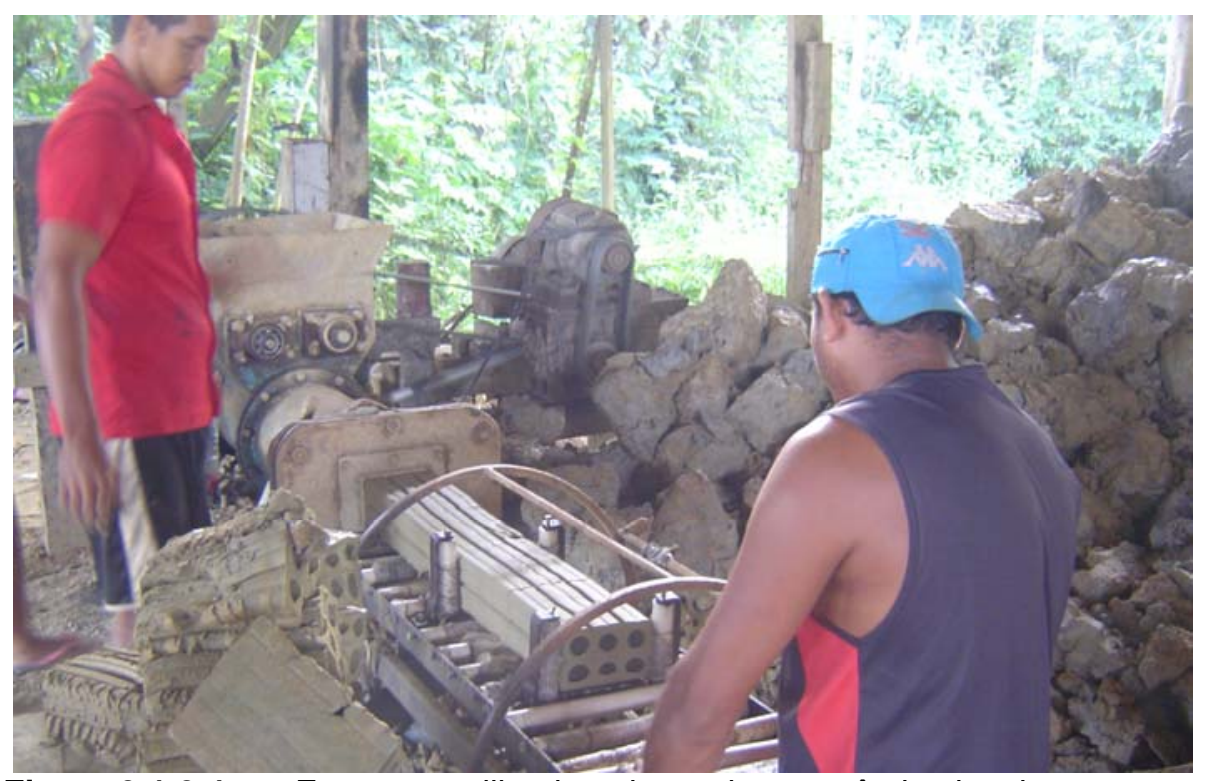

Figura 3.1.2.4 - Extrusora utilizada pelo produtor cerâmico local. 
Em Laranjal do Jarí, cidade que no ano 2000, de acordo com o IBGE, situava-se em $2380^{\circ}$ lugar em termos de Índice de Desenvolvimento Humano - Municipal, existem pelo menos nove olarias como essa, como informaram funcionários desse empreendimento. A cidade que hoje conta com pouco mais de 40.000 habitantes, de acordo com a Fundação Orsa, instituição sem fins lucrativos criada há 15 anos pelo Grupo Orsa, atual controlador da Jarí Celulose, como resultado de levantamento feito no municipio, registra em torno de 9.000 casas, sendo que mais de 6.000 delas na modalidade de "palafita" (Figura 3.1.2.5). As condições de moradia em palafitas são precárias em termos de higiene, conforto e segurança para seus moradores, além de representar irregularidade por ocuparem áreas de preservação permanente e constituirem pontos de lançamentos de efluentes domésticos e sanitarios que poluem o rio local.

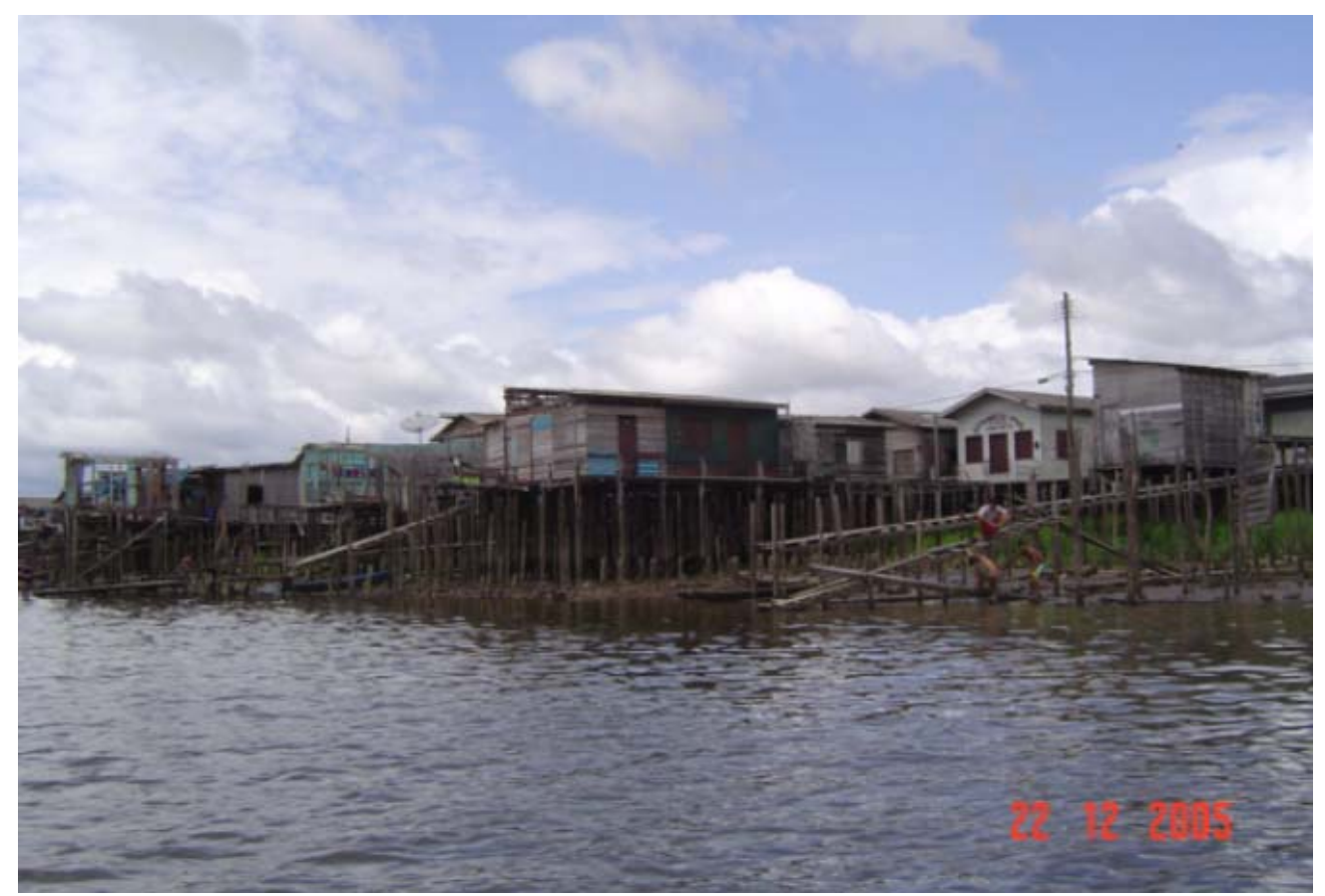

Figura 3.1.2.5 - Construções do tipo "palafitas",isto é, sustentadas por estacas de madeira cravadas no fundo dos rios, próximo a suas mar gens, predominantes em Laranjal do Jari, Estado do Amapa,em fotografia tirada pelo autor. 
Assim, observa-se naquela região a necessidade de se transferir a população para locais mais distantes das áreas de proteção ambiental e tambem sob condições mais seguras. Em 2006 registrou naquela localidade um incêndio de grandes proporções em função da precariedade das instalações existentes e do tipo de material de construção (Figura 3.1.2.6).

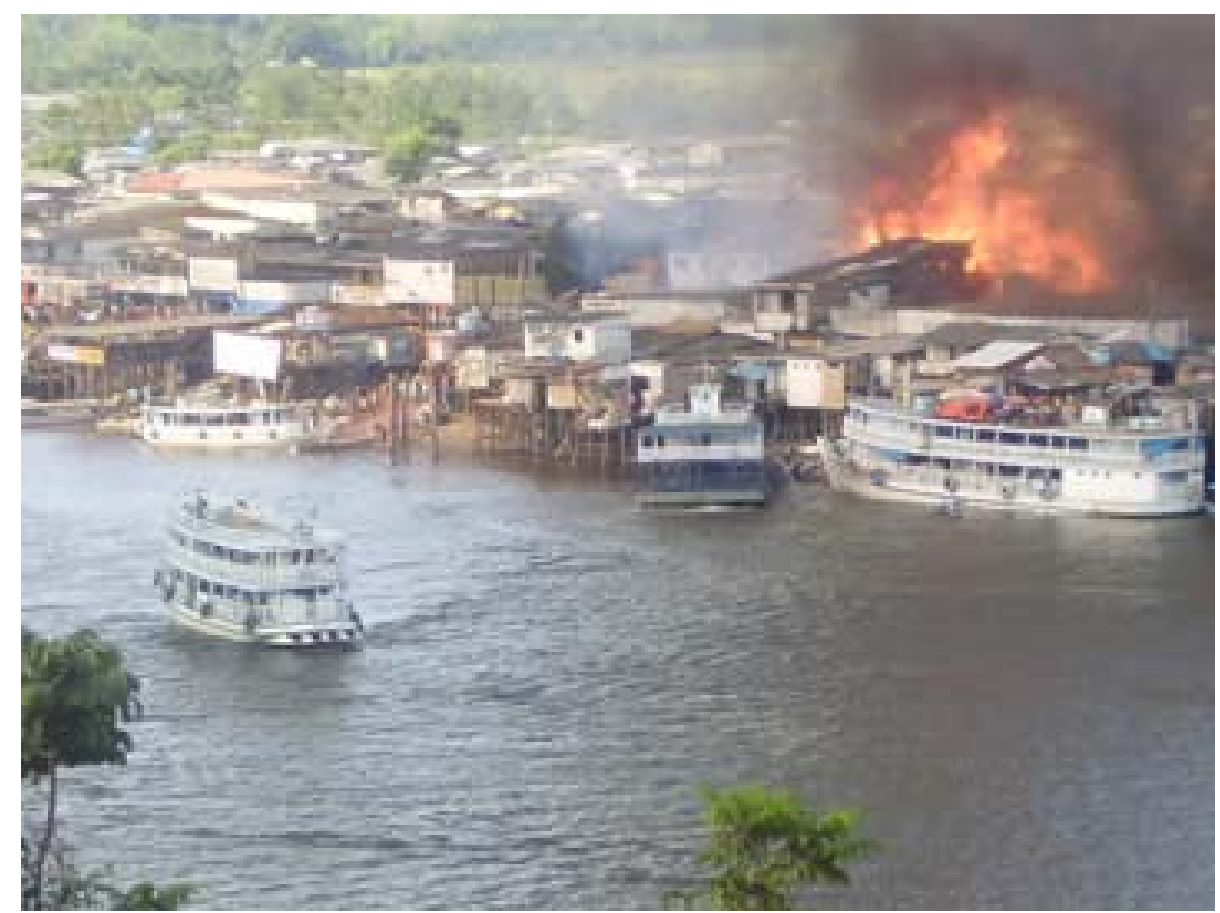

Figura 3.1.2.6 - Imagem registrada pelo autor durante incêndio que se Deu em Laranjal do Jari, AP, em 2006.

Existe a necessidade do poder público, em especial, investir em programas de habitação popular com o emprego de materiais regionais de custo acessível que confiram mais segurança e salubridade aos moradores, como são as habitações de alvenaria, construídas com tijolos cerâmicos e similares e ligantes como cal e argamassas baseadas em cimento. 
Na Figura 3.1.2.7, reprodução de uma imagem de satélite, mostra a localização da Jarí Celulose, onde são gerados os resíduos objetos de estudo, e a localização do município de Laranjal do Jarí, com a posição aproximada da olaria onde são produzidos os tijolos e telhas que alimentam o mercado da região. A distância entre o ponto de geração dos resíduos, indústria de celulose, e o ponto de produção cerâmica é de $23 \mathrm{~km}$.

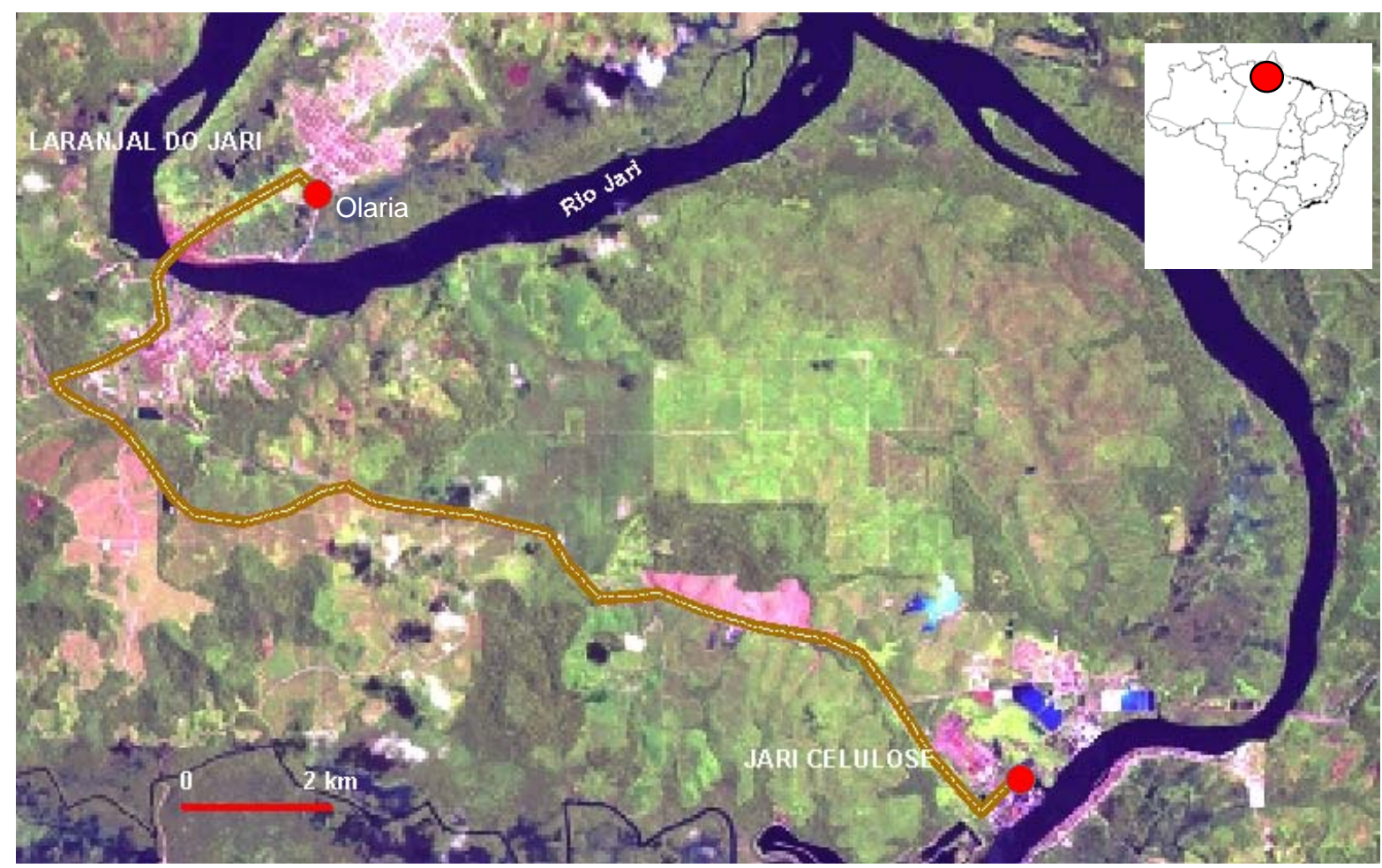

Figura 3.1.2.7 - $\quad$ Localizações do ponto de geração dos resíduos (Jarí Celulose), situado no Distrito de Monte Dourado, em Almeirim, PA, e da olaria, situada no perímetro urbano de Laranjal do Jari, AP.

De acordo com ERENO (2009), a distância limite econômica para a destinação desses resíduos não perigosos é de $100 \mathrm{~km}$. Portanto, a distância entre geração e destino encontrada nest e trabalho situa-se, à princípio, dentro de um raio de potencial econômico. Por outro lado, considerando-se o custo de transporte, que é o 
elemento mais impactante no processo comercial desses resíduos, o frete para distâncias dessa magnitude pode ser estimado num valor maximo da ordem de $\mathrm{R} \$$ 15,00 por tonelada, de acordo com o memorial de cálculos que apresentamos na Tabela 3.1.2.1. O computo do valor de frete tem sempre uma relação direta com o custo do combustível, no caso o óleo diesel. Como regra usualmente considerada no setor de transportes é considerada a proporção do peso do combustível sobre o custo de transporte. O valor de um frete tem que ser no mínimo três vezes o custo que se tem com combustível ao realiza-lo.

Tabela 3.1.2.1 - Demonstrativo dos elementos considerados na estimativa do valor de frete esperado para o transporte de resíduos de onde é gerado até a Olaria no município vizinho de Laranjal do Jari,AP.

\begin{tabular}{lrl}
\hline Parâmetro & Valor & Unidade \\
\hline distancia & 46 & $\mathrm{~km}$ \\
consumo relativo combustíveis & 0,5 & Litros/km \\
consumo combustível no trajeto & 23 & Litros \\
custo unitário combustível & 2,5 & $\mathrm{R} \$ /$ litro \\
custo total combustível no trajeto & 57,50 & $\mathrm{R} \$$ \\
valor mínimo estimado para o frete por viagem & 172,50 & $\mathrm{R} \$$ \\
peso médio de carga & 12 & Toneladas \\
frete relativo & 14,38 & $\mathrm{R} \$ /$ tonelada \\
\hline
\end{tabular}

Verifica-se que o valor do frete acima demonstrado representa um custo bem inferior ao custo de disposição em aterros, o qual, conforme discutido no capitulo anterior, atinge níveis da ordem de $\mathrm{R} \$ 50,00 /$ t. Ou seja, é mais vantajoso economicamente para a empresa doar os resíduos para a industria cerâmica do que dispo-lo em aterros como vinha sendo feito no momento da coleta desses materiais para os estudos, cujos resultados são a matéria desta tese. 


\subsection{MÉTODOS}

Os métodos empregados para se atingir os objetivos dos trabalhos incluíram a caracterização individual dos materiais, a preparação de misturas em proporções variadas e a posterior conformação de corpos de prova, tratamentos térmicos e finalmente a avaliação das propriedades dos produtos gerados, de acordo com os procedimentos abaixo descritos.

\subsubsection{Caracterização física dos materiais}

Para caracterização física dos materiais foi feita inicialmente a secagem dos mesmos em estufa a $110^{\circ} \mathrm{C}$ por 48 horas. Pesando-se o material antes e depois da secagem foi determinado o teor de umidade. Na Figura 3.2.1.1 apresenta-se os materiais empregados nos estudos, já secos, processados nas instalações do LMPSol Laboratório de Matérias Primas Particuladas e Sólidos Inorgânicos Não Metálicos do Departamento de Engenharia Metalúrgica e de Materiais da Escola Politécnica da Universidade de São Paulo.

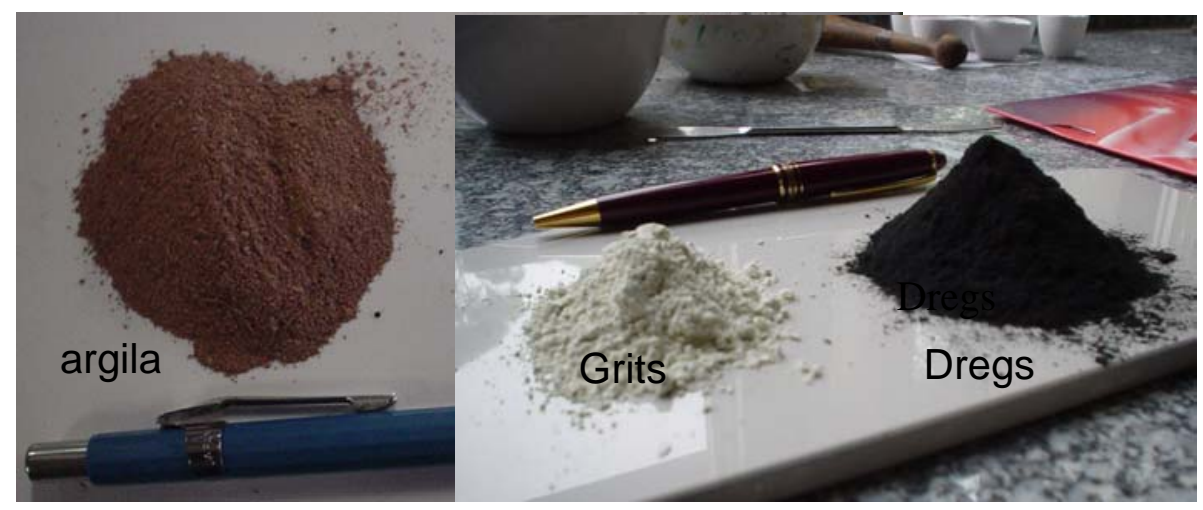

Figura 3.2.1.1 - Amostras dos materiais de partida secos, na bancada do LMPSol (Arquivo do autor). 
O teor de umidade dos materiais foi considerado relacionando-se os pesos iniciais, dos materiais nas condições como são gerados, no caso dos resíduos, e de como são extraídos, no caso da argila.

Além da determinação da umidade dos materiais, para os resíduos foi determinada também a distribuição granulométrica através de métodos de peneiramento e pipetagem, junto ao laboratório do Instituto Geológico da Secretaria de Estado do Meio Ambiente (SP).

\subsubsection{Caracterização química dos materiais}

As composições químicas, expressas em termos de óxidos, foram realizadas pelo LCT - Laboratório de Caracterização Tecnológica, do Departamento de Engenharia de Minas e de Petróleo da EPUSP, pelo método de fluorescência de raios X, utilizando equipamento Philips modelo PW 2400. O método de fluorescência de raios $X$ é o método usual para caracterizar-se quimicamente materiais inorgânicos e minerais e baseia-se no princípio de que a absorção de raios $X$ por parte do material provoca transições eletrônicas (excitação) nos átomos, cujos decaimentos emitem radiação secundária denominada fluorescência de raios $X$. Os raios emitidos permitem estabelecer-se, por meio da comparação com espectros padrão, a identificação dos elementos químicos presentes (análise química qualitativa), permitindo estabelecer-se também uma análise semi-quantitativa. 


\subsubsection{Ensaios cerâmicos}

Os ensaios cerâmicos foram feitos com corpos de prova contendo 0, 10, 20 e 40\% (em massa) de resíduos, sendo estes incorporados em iguais proporções de dregs e grits; isto é, $10 \%$ de resíduos significam $5 \%$ de dregs e $5 \%$ de grits. As formulações utilizadas são mostradas na Tabela 3.2.3.1.

Tabela 3.2.3.1 - Formulações estudadas (valores em \% em massa).

\begin{tabular}{|c|c|c|c|}
\hline FORMULAÇÃO & DREGS & GRITS & ARGILA \\
\hline 1 & 0 & 0 & 100 \\
\hline 2 & 5 & 5 & 90 \\
\hline 3 & 10 & 10 & 80 \\
\hline 4 & 20 & 20 & 60 \\
\hline
\end{tabular}

O objetivo foi verificar as propriedades dos materiais obtidos com e sem esses resíduos, buscando prospectar uma nova rota de destinação dos mesmos. Para melhor visualização, as formulações são mostradas graficamente na Figura 3.2.3.1.

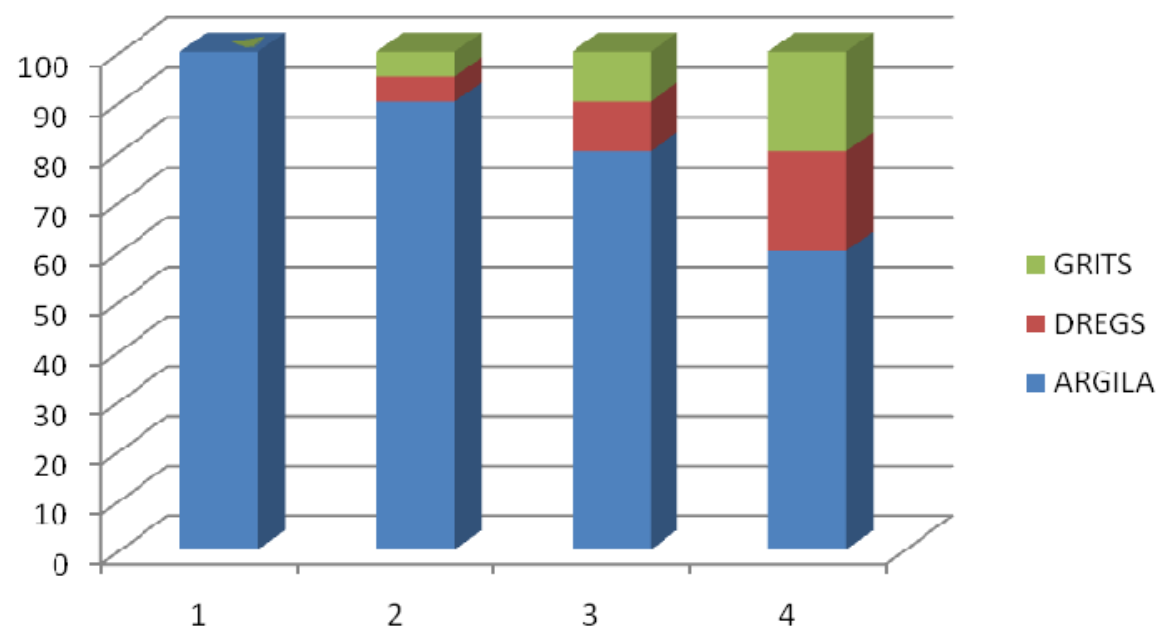

Figura 3.2.3.1. Formulações empregadas no estudo. 
Para produção dos corpos de provas, o material particulado foi prensado uniaxialmente a $25 \mathrm{MPa}$, em molde de aço, nas dimensões de $(60 \times 20 \times 5) \mathrm{mm}^{3}$. As partes do molde são mostradas na Figura 3.2.3.2.

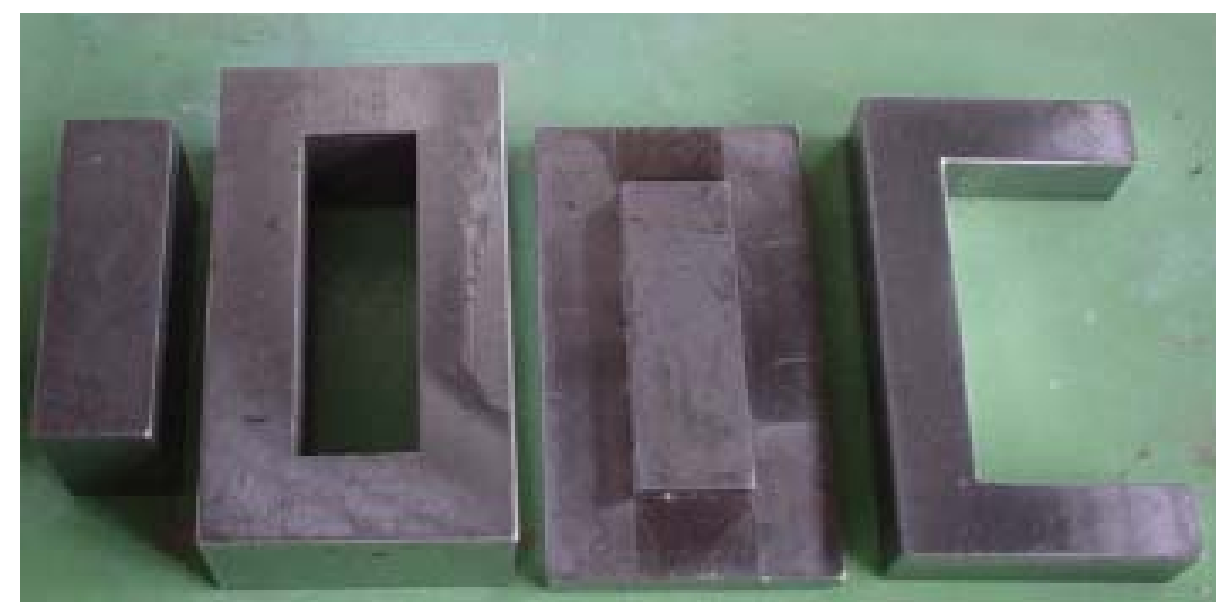

Figura 3.2.3.2 - Componentes do molde utilizado na prensagem dos corpos de prova

A prensagem foi realizada em prensa hidráulica (Figura 3.2.3.3) com pressão aplicada de 3 toneladas (25 MPa). Exemplos de corpos de prova prensados são apresentados à Figura 3.2.3.4.

Após serem prensados, os corpos de prova foram submetidos a secagem e calcinação. A secagem teve por finalidade eliminar os cerca de $5 \%$ de água contida na amostra, introduzida para obter compactação mais eficiente, e foi realizada em estufa de laboratório a $110^{\circ} \mathrm{C}$, por 48 horas.

Para a queima (calcinação), utilizou-se as temperaturas de 900 e $1000^{\circ} \mathrm{C}$, a uma taxa de aquecimento da ordem de $10^{\circ} \mathrm{C} /$ minuto, permanecendo na temperatura máxima 
por 60 minutos. O resfriamento foi por perda natural de calor. O equipamento utilizado foi um forno de laboratório EDG Equipamentos, modelo 1800 (Figura 3.2.3.5).

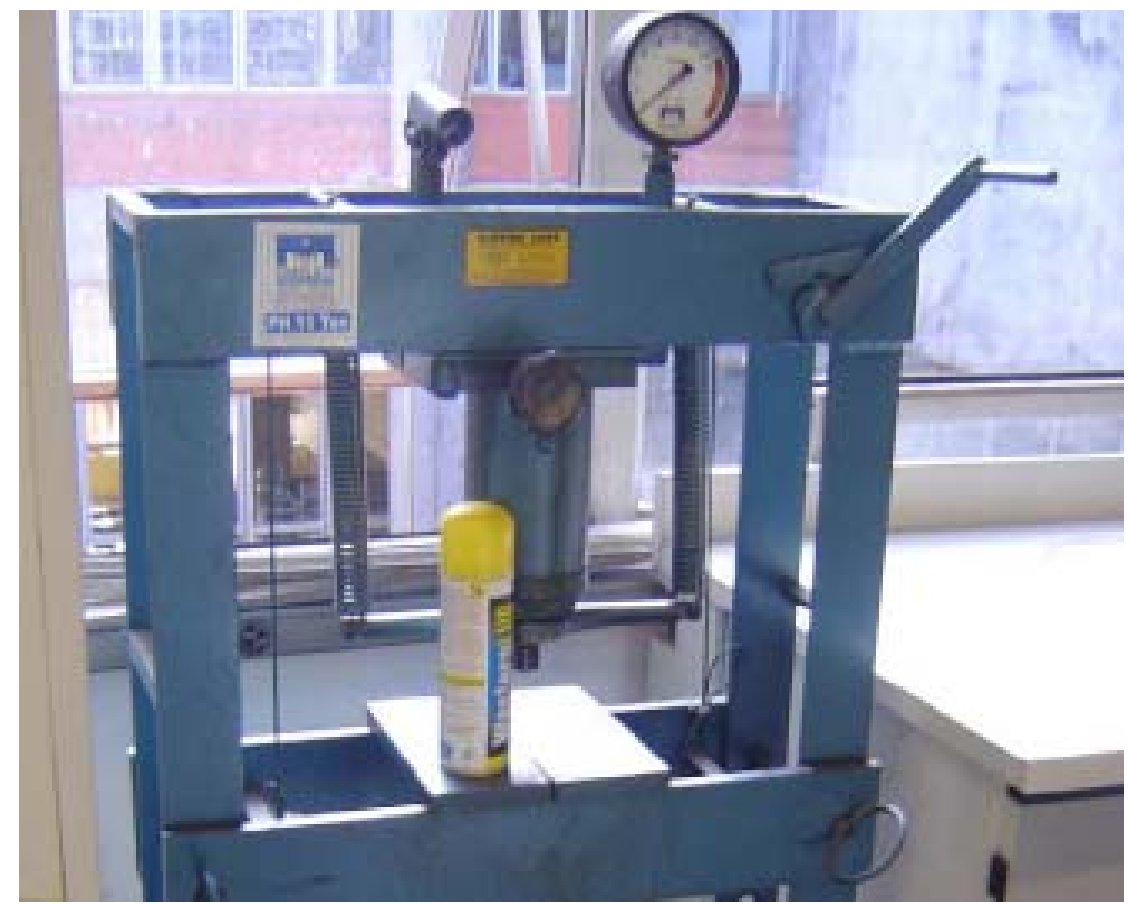

Figura 3.2.3.3 - Equipamento usado para prensagem dos corpos de prova nas dependências do LMPSol.

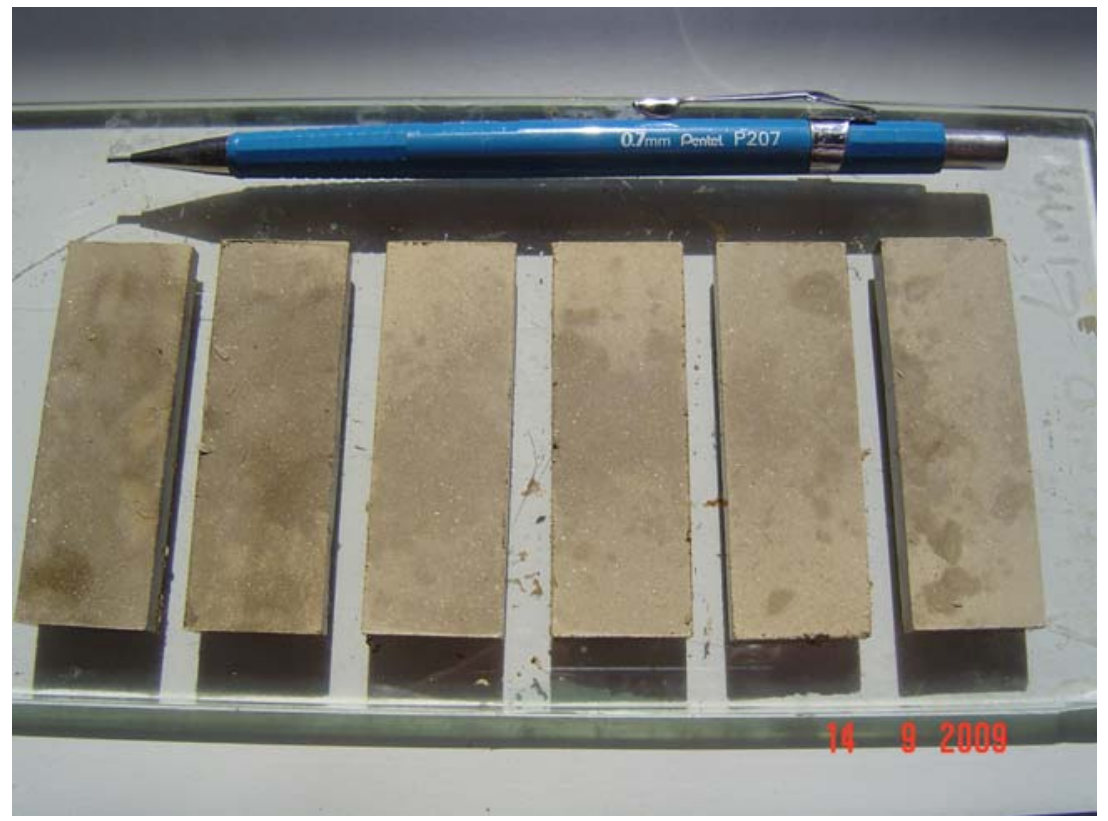

Figura 3.2.3.4 - Amostras recém-prensadas, antes da queima. 


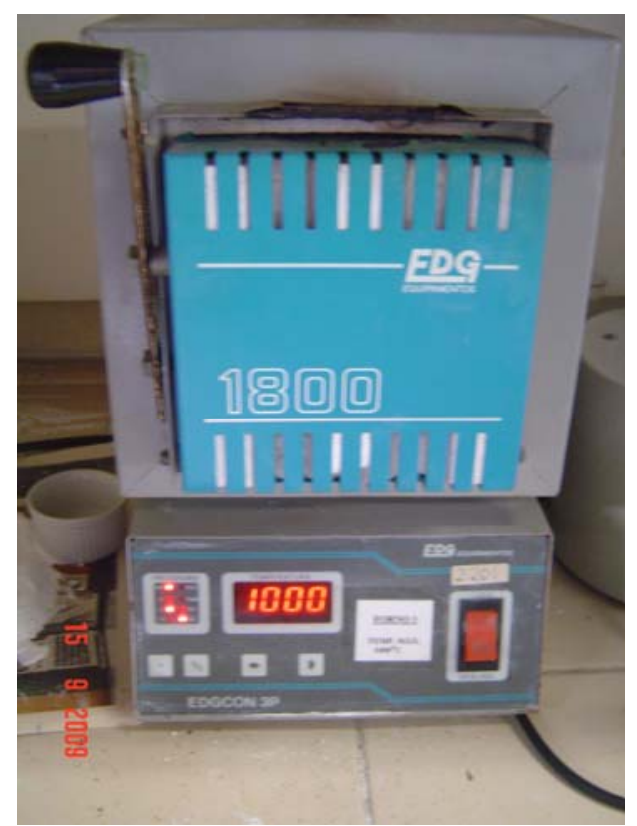

Figura 3.2.3.5. Forno utilizado para a calcinação.

Para cada formulação e para cada temperatura de queima foram preparados 5 corpos de prova. Os ensaios foram realizados com todos os corpos de prova, de maneira a fornecer dados experimentais que permitissem calcular-se médias dos resultados para cada tipo de ensaio.

As propriedades cerâmicas obtidas foram: absorção de água, massa especifica aparente (ou densidade aparente), porosidade aparente (porosidade aberta), resistência mecânica à flexão em três pontos ("módulo de ruptura") e retração linear. Todos esses ensaios foram feitos no Laboratório de Matérias Primas Particuladas e Sólidos Inorganicos Não-Metálicos - LMPSol, da Escola Politécnica da USP.

Essas propriedades de interesse cerâmico são referenciais para a performance do produto que se pretendeu gerar, principalmente quando se compara os resultados obtidos para corpos de prova de argila pura com aqueles obtidos para corpos de prova que receberam a adição de resíduos. 


\subsubsection{Absorção de água}

Para determinação da Absorção de Água após calcinação e resfriamento para a temperatura ambiente, os corpos de prova foram pesados e a seguir imersos em água à temperatura ambiente, onde permaneceram por 24 horas. Após esse período foram retirados e imediatamente pesados, sendo esta propriedade calculada pela fórmula:

$$
\begin{aligned}
& A A(\%)=\frac{P_{u}-P_{q}}{P_{q}} \times 100 \\
& \text { Onde: } \quad A A=\text { absorção de água } \\
& \mathrm{Pu}=\text { peso úmido } \\
& \mathrm{Pq}=\text { peso queimado }
\end{aligned}
$$

\subsubsection{Massa específica aparente}

A massa especifica aparente, após secagem, foi determinada pelo método geométrico. O volume foi calculado a partir das medidas do comprimento, largura e espessura de cada corpo-de-prova; a massa foi determinada em balança digital, com precisão de 0,01 g, existente no LMPSol. A massa especifica aparente foi calculada pela media da relação massa/volume dos corpos de prova. 


\subsubsection{Porosidade aparente}

O ensaio de porosidade aparente (PA) após queima foi determinado através do emprego da seguinte fórmula:

$$
P A(\%)=\frac{P_{u}-P_{q}}{P_{u}-P_{i}} \times 100
$$

Onde:

$$
\begin{aligned}
& \mathrm{PA}=\text { porosidade aparente } \\
& \mathrm{Pu}=\text { peso do corpo de prova úmido } \\
& \mathrm{Pq}=\text { peso do corpo de prova queimado } \\
& \mathrm{Pi}=\text { peso do corpo de prova imerso em água }
\end{aligned}
$$

\subsubsection{Resistência mecânica à flexão}

A resistência mecânica das peças cerâmicas foi determinada por meio do ensaio de flexão em três pontos, baseado na norma ASTM C1161/02c. Foi realizado em máquina de ensaios universal, mostrada na Figura 3.2.3.4.1, com velocidade de cabeçote de $0,5 \mathrm{~mm} / \mathrm{min}$ e célula de carga de $5 \mathrm{kN}$. 


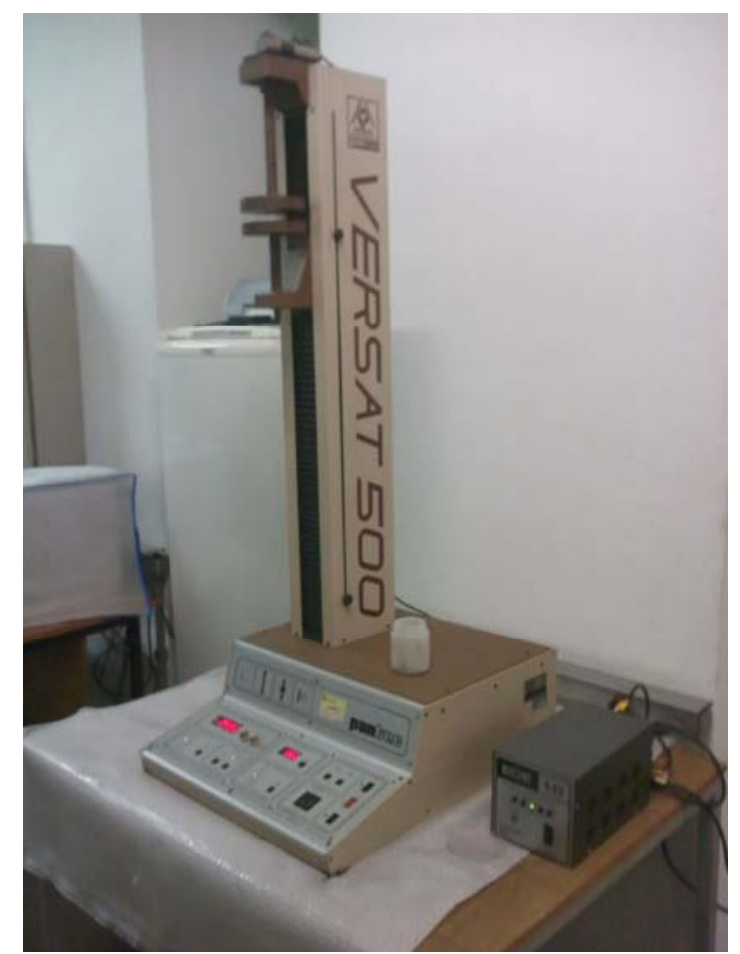

Figura 3.2.3.4.1. Máquina de ensaios mecânicos usada na determinação da resistência mecânica à flexão em 3 pontos.

Os valores finais para essa propriedade foram apresentados na forma de médias aritméticas dos resultados.

A resistência mecânica à flexão em 3 pontos (também chamada de "TRF - tensão de ruptura à flexão", ou ainda "módulo de ruptura") foi calculada através da seguinte formula:

$$
T R F=\frac{3 \cdot P \cdot L}{2 \cdot b \cdot d^{2}}
$$

Onde: $\quad$ TRF $=$ tensão de ruptura à flexão $(\mathrm{MPa})$

$\mathrm{P}=$ força de ruptura $(\mathrm{N})$

$\mathrm{L}=$ distância entre os apoios $(40 \mathrm{~mm})$

$\mathrm{b}=$ largura do corpo de prova $(\mathrm{mm})$

$\mathrm{d}=$ espessura do corpo de prova $(\mathrm{mm})$ 


\subsubsection{Retração linear na queima}

Todos os corpos, após a secagem e após a queima tiveram suas dimensões medidas para determinação da retração, relativa à variação de seus comprimentos, de acordo com a fórmula:

$$
\% R t=\frac{C_{i}-C_{q}}{C_{i}} \times 100
$$

Onde: $\quad \mathrm{C}_{\mathrm{q}}=$ comprimento do corpo de prova queimado

$\mathrm{C}_{\mathrm{i}}=$ comprimento inicial do corpo de prova, a verde

\subsubsection{Difração de raios $X$}

Os ensaios de difração de raios $X$ foram realizados com a finalidade de se observar quais as principais fases cristalinas presentes tanto nos materiais individuais, como nas composições que resultaram em melhores propriedades cerâmicas, a cru e após a calcinação.

A principal aplicação da difração de raios $X$ refere-se à identificação de fases cristalinas, sejam elas inorgânicas ou orgânicas. Os planos de difração e suas respectivas distâncias interplanares, bem como as densidades de átomos de cada plano cristalino, são características especificas e únicas de cada fase cristalina. 
Assim, o método permite investigar qualitativamente a composição mineralógica do material avaliado. O equipamento utilizado foi um difratômetro Philips X'PERT MPD,

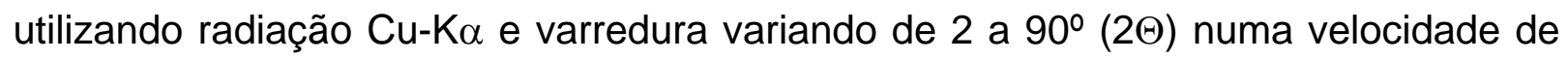
$1 \%$ min, pertencente ao LMPSol - EPUSP.

\subsubsection{Análise térmica diferencial}

Uma vez que os ensaios básicos para avaliação do uso do resíduo na indústria cerâmica envolvem calcinação, foram feitas análises térmicas dos materiais e formulações envolvidas. A análise termogravimétrica (TG) com análise termodiferencial (ATD) simultânea foi realizada em analisador térmico simultâneo TA Instruments, modelo SDT 2960, utilizando atmosfera de ar sintético e taxa de aquecimento de $10^{\circ} \mathrm{C} / \mathrm{min}$. As análise foram realizadas até a temperatura de $1200^{\circ} \mathrm{C}$.

O termo análise térmica envolve uma série de técnicas que analisam os fenômenos de transformação que ocorrem nas matérias-primas isoladas e nas composições estudadas, em função do tratamento térmico a ser empregado. Essas reações podem ser associadas a efeitos endotérmicos e exotérmicos, sendo que as principais são: desidratações, dissociações e/ou decomposições, transformações (ou inversões) de fase, fusões, reações químicas, sublimação, vaporização, oxidação, redução e outras reações [5]. Geralmente, desidratações, reduções e algumas reações de decomposição produzem efeitos endotérmicos, enquanto que cristalização e oxidação produzem efeitos exotérmicos. 
As principais técnicas de termoanálises são:

- Termogravimetria (TG) / Termogravimetria derivada (DTG);

- Análise térmica diferencial (ATD);

- Calorimetria exploratória diferencial (DSC);

- Análise dinâmico-mecânica (DMA).

- Análise térmica dinâmico-mecânica (DMTA);

\subsubsection{Microscopia eletrônica de varredura}

A morfologia das partículas dos materiais individuais e das formulações foi observada por microscopia eletrônica de varredura (MEV). As imagens de MEV foram obtidas num microscópio Philips XL30, com analisador EDS (Energy Dispersive Spectroscopy) acoplado, pertencente ao Laboratório de Microscopia Eletrônica do PMT-EPUSP. Empregou-se aumentos de 100 a 25.000 vezes buscando melhores definições e observações das estruturas e morfologias dos materiais.

\subsubsection{Ensaio de solubilização}

Para avaliar-se os resíduos quanto à sua natureza e classificação e a influência de sua incorporação na estabilidade dos materiais cerâmicos obtidos, foi realizado ensaio de solubilização, baseado na norma ABNT:NBR 10006. O objetivo do ensaio foi o de verificar se os resíduos, classificados originariamente pela norma como nãoinertes, alterariam a classificação das massas cerâmicas queimadas (inertes, originalmente), ou seja, se as matrizes cerâmicas teriam a capacidade de inertizar tais resíduos. 
Em linhas gerais, esse ensaio consiste na colocação do material sob análise em água destilada, na proporção de $250 \mathrm{~g}$ (base seca) do material a $1000 \mathrm{~mL}$ de água destilada, em frasco de capacidade de $1500 \mathrm{~mL}$. O sistema deve ser agitado em baixa velocidade por 5 minutos. Após a agitação, o material deve ficar 7 dias em temperatura de até $25^{\circ} \mathrm{C}$, após o que o material deve ser filtrado e o solubilizado ser analisado para os elementos relacionados no Anexo G da norma ABNT:NBR 10004, a qual determina os máximos valores para a série mostrada na Tabela 3.2.7.1, de maneira que um material possa ser considerado inerte quimicamente.

Este ensaio foi feito com os resíduos e com o material cerâmico, obtido após calcinação, no laboratório da empresa Puriquima (São Paulo, SP).

Tabela 3.2.7.1. Padrões para ensaio de solubilização, com indicação dos valores máximos permitidos no solubilizado de acordo com a norma ABNT:NBR 10.004.

\begin{tabular}{|l|r|l|r|}
\hline Parâmetro & Máximo (mg/L) & Parâmetro & Máximo (mg/L) \\
\hline Aldrin e dieldrin & $3,0 \times 10^{-5}$ & Heptacloro e seu epóxido & $3,0 \times 10^{-5}$ \\
\hline Aluminio & 0,2 & Hexaclorobenzeno & $1,0 \times 10^{-3}$ \\
\hline Arsenio & 0,01 & Lindano (y-BHC) & $2,0 \times 10^{-3}$ \\
\hline Bario & 0,7 & Manganes & 0,1 \\
\hline Cadmio & 0,005 & Mercurio & 0,001 \\
\hline Chumbo & 0,01 & Metoxicloro & 0,02 \\
\hline Cianeto & 0,07 & Nitrato (expresso em N) & 10 \\
\hline Clordano (todos os isomeros) & $2,0 \times 10^{-4}$ & Prata & 0,05 \\
\hline Cloreto & 250 & Selenio & 0,01 \\
\hline Cobre & 2 & Sodio & 200 \\
\hline Cromo total & 0,05 & Sulfato (expresso em SO4) & 250 \\
\hline 2,4 - D & 0,03 & Surfactantes & 0,5 \\
\hline DDT (todos os isomeros) & $2,0 \times 10^{-3}$ & Toxafeno & $5,0 \times 10^{-3}$ \\
\hline Endrin & $6,0 \times 10^{-4}$ & $2,4,5-\mathrm{T}$ & $2,0 \times 10^{-3}$ \\
\hline Fenóis totais & 0,01 & $2,4,5-T P$ & 0,03 \\
\hline Ferro & 0,3 & Zinco & 5 \\
\hline Fluoreto & 1,5 & &
\end{tabular}




\subsubsection{Teste preliminar de produção}

Após a obtenção dos resultados físicos e quimicos das peças produzidas, sob as condições normais de produção da olaria de onde foram tomadas amostras da argila, foi feito teste de produção industrial no mesmo local com o uso de resíduos misturados com a argila na proporção ideal indicada pelos resultados dos ensaios.

O objetivo desse teste de produção foi o de verificar a possibilidade de, na pratica, empregar os resíduos na rotina daquela olaria e se os resultados, pelo menos aparentemente, seriam satisfatórios.

Foram produzidas 5 (cinco) peças utilizando o equipamento de mistura e extrusão da empresa. Essas peças foram marcadas com um circulo sobre uma das faces da mesma com o uso do bocal de uma garrafa pet, para poder identifica-la posteriormente, após a queima conjunta, dentre os materiais produzidos essencialmente com argila. 


\section{RESULTADOS E DISCUSSÃO}

As características físicas, químicas e cerâmicas dos materiais isolados e combinados nas proporções e procedimentos descritos, foram determinadas e são apresentadas e discutidas a seguir.

\subsection{CARACTERIZAÇÃO FÍSICAS DOS MATERIAIS}

Os resíduos apresentaram, de modo geral, uma granulometria muito fina, principalmente o dregs, sendo o grits um pouco mais granular, características que podem ser observadas, respectivamente, na Figura 4.1.1 e Figura 4.1.2.

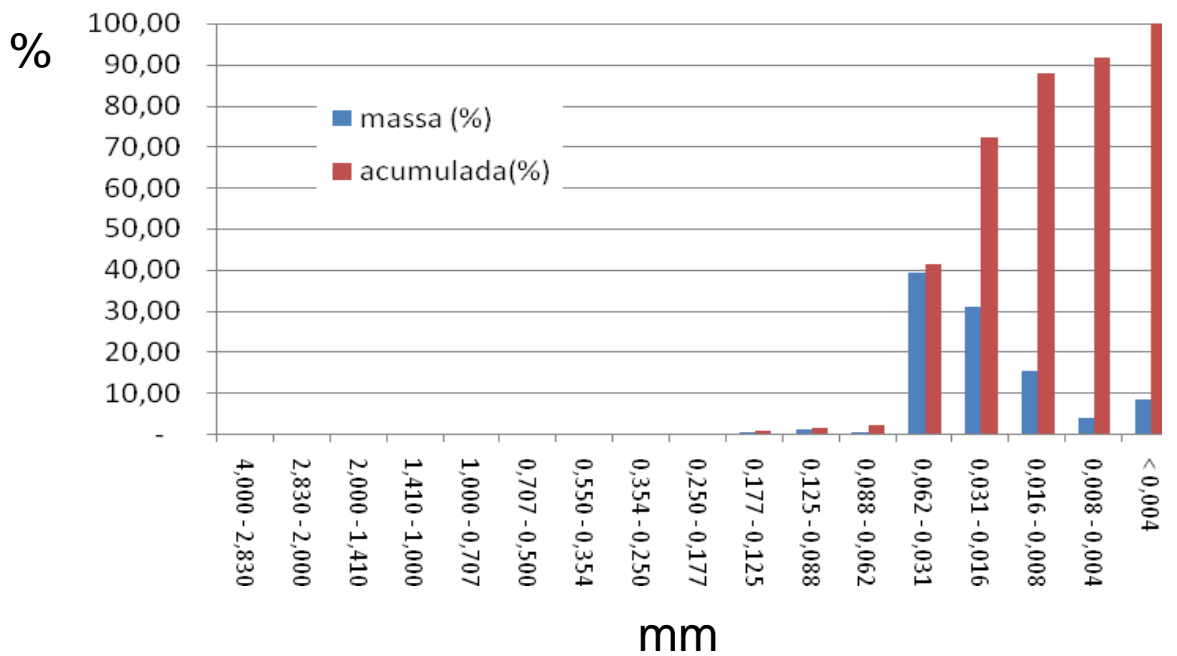

Figura 4.1.1. Distribuição granulométrica do dregs. 


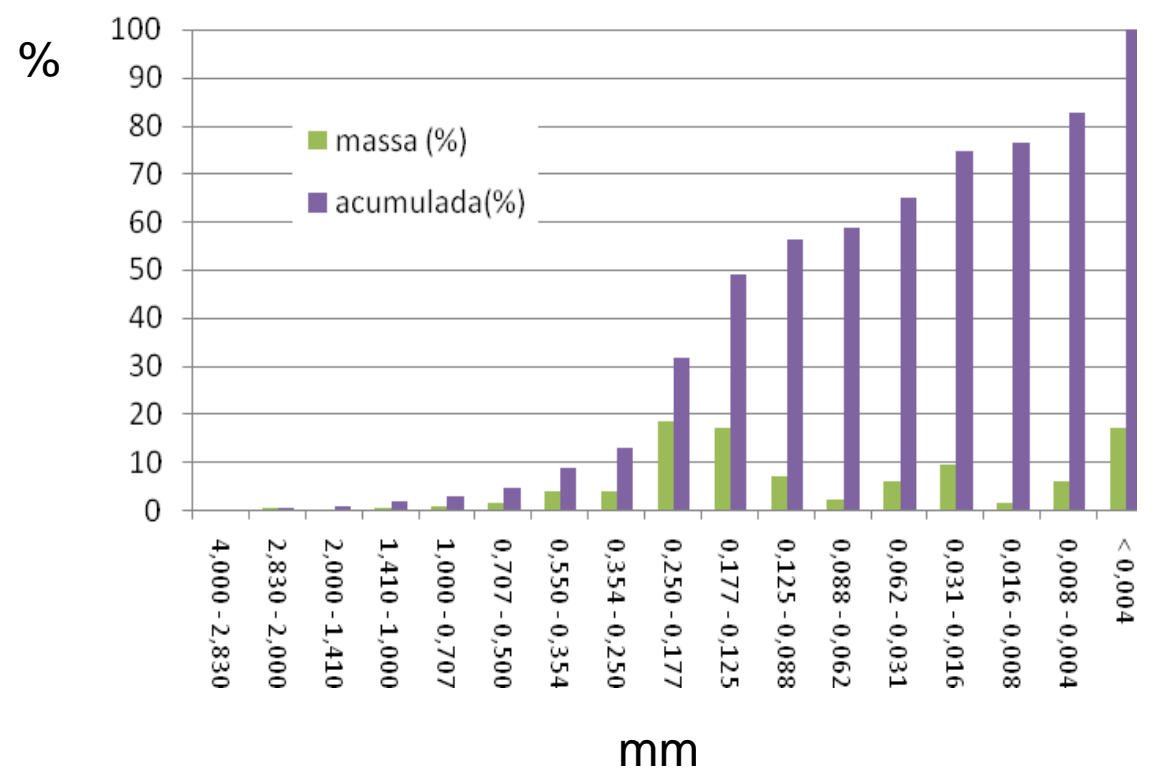

Figura 4.1.2. Distribuição granulométrica do grits.

Do ponto de vista de classificação granulométrica, o resíduo dregs tem uma composição predominantemente síltico-argilosa, com maior concentração entre $30 \mathrm{e}$ $60 \mu \mathrm{m}$, enquanto que o grits, mais arenosa, apresenta partículas entre 125 e 250 $\mu \mathrm{m}$. Dos resíduos, o grits é o que apresenta-se pior selecionado, em termos de distribuição granulométrica, isto é, sua granulometria se distribui por uma faixa relativamente mais ampla de tamanhos. Isso naturalmente é resultado de uma formação por aglomeração de particulas de meios diversos, resultados provavel da incorporação não só de impurezas da rocha calcaria calcinada para produção de cal, como tambem de residuos do proprio forno, de seus refratarios, e da propria lama de cal reprocessada.

Os teores de umidade dos resíduos como são gerados superam $30 \%$, similar à da argila (Tabela 4.1.1). A argila, em função do ambiente de sua formação tem também umidade elevada. 
Tabela 4.1.1. Umidade dos materiais.

\begin{tabular}{|crr|}
\hline Materiais & Medidas & Médias \\
\hline ARGILA & $36,9 \%$ \\
\cline { 2 - 2 } & $\begin{array}{l}40,5 \% \\
\end{array}$ & $38,4 \%$ \\
\hline DREGS & $37,7 \%$ & \\
& $36,7 \%$ & \\
& $37,4 \%$ & $37,0 \%$ \\
\cline { 2 - 2 } & $37,0 \%$ & \\
\hline GRITS & $31,5 \%$ & \\
& $30,9 \%$ & $31,2 \%$ \\
& $31,3 \%$ & \\
\hline
\end{tabular}

\subsection{CARACTERIZAÇÃO QUÍMICA DOS MATERIAIS}

Os resultados das análises químicas por FRX são apresentados à Tabela 4.2.1. Os resíduos estudados têm como maiores constituintes o óxidos de cálcio e de sódio, compostos estes diretamente relacionados aos reagentes utilizados na produção de celulose e no processo de recuperação química, quais sejam a soda e a cal virgem. Os materiais analisados mostraram uma perda ao fogo relativamente elevada e semelhantes, fato que já era antecipado, uma vez que ambos contêm carbonatos oriundos das reações apresentadas e discutidas na revisão da literatura. Assim, a perda ao fogo refere-se principalmente à decomposição dos carbonatos em $\mathrm{CaO}$ (sólido) e $\mathrm{CO}_{2}$ (gasoso). A argila mostra-se como uma argila caulinítica com poucas impurezas, uma vez que se constitui quase somente de $\mathrm{SiO}_{2}$ e $\mathrm{Al}_{2} \mathrm{O}_{3}$. 
Tabela 4.2.1. Composição química por FRX dos materiais estudados.

\begin{tabular}{|c|c|c|c|}
\hline NLCT & $3879 / 08$ & $3881 / 08$ & $3882 / 08$ \\
\hline Amostra & dregs $\# 200$ & argila $\# 200$ & gritts \\
\hline $\mathrm{Na}_{2} \mathrm{O}$ & 2,70 & 0,08 & 8,56 \\
\hline $\mathrm{MgO}$ & 0,98 & nd & 1,24 \\
\hline $\mathrm{Al}_{2} \mathrm{O}_{3}$ & 0,52 & 34,6 & 2,28 \\
\hline $\mathrm{SiO}_{2}$ & 0,58 & 46,1 & 2,42 \\
\hline $\mathrm{P}_{2} \mathrm{O}_{5}$ & 0,13 & 0,24 & 0,14 \\
\hline $\mathrm{SO}_{3}$ & 0,94 & 0,13 & 2,50 \\
\hline $\mathrm{Cl}$ & 0,06 & nd & 0,24 \\
\hline $\mathrm{K}_{2} \mathrm{O}$ & 0,13 & 0,03 & 0,65 \\
\hline $\mathrm{CaO}$ & 50,7 & 0,12 & 44,1 \\
\hline $\mathrm{TiO}_{2}$ & nd & 1,86 & nd \\
\hline $\mathrm{Cr}_{2} \mathrm{O}_{3}$ & nd & 0,02 & nd \\
\hline $\mathrm{MnO}$ & 0,11 & nd & 0,02 \\
\hline $\mathrm{Fe}_{2} \mathrm{O}_{3}$ & 0,17 & 2,03 & 0,19 \\
\hline $\mathrm{CuO}$ & 0,01 & nd & nd \\
\hline $\mathrm{ZnO}$ & 0,01 & $\ll$ & nd \\
\hline $\mathrm{Ga}_{2} \mathrm{O}_{3}$ & nd & 0,01 & nd \\
\hline $\mathrm{Rb}_{2} \mathrm{O}$ & nd & nd & $\ll$ \\
\hline $\mathrm{SrO}$ & 0,14 & 0,01 & 0,21 \\
\hline $\mathrm{Y}_{2} \mathrm{O}_{3}$ & nd & 0,01 & nd \\
\hline $\mathrm{ZrO}_{2}$ & nd & 0,75 & nd \\
\hline $\mathrm{Nb}_{2} \mathrm{O}_{5}$ & nd & 0,01 & nd \\
\hline $\mathrm{MoO}_{3}$ & nd & nd & $\ll$ \\
\hline $\mathrm{HfO}_{2}$ & nd & 0,02 & nd \\
\hline $\mathrm{PbO}$ & nd & 0,01 & nd \\
\hline $\mathrm{ThO}_{2}$ & nd & $\ll$ & nd \\
\hline PF & 42,9 & 14.0 & 37,5 \\
\hline
\end{tabular}

Deve-se destacar que tanto o sódio quanto o cálcio, elementos químicos classificados respectivamente como alcalino e alcalino terroso, possuem uma ação fundente nas massas cerâmicas onde estão presentes. De acordo com LENGLER, H.C.et al. (2009):

"Fundente é uma substância que baixa a temperatura de sinterização do material ou composto ao qual é adicionado. A atuação de uma substância como fundente depende do material ao qual é adicionada. Existem certos materiais que são geralmente observados como fundentes, possuindo alto conteúdo de compostos alcalinos e alcalinos terrosos. " 
O mesmo autor destaca ainda que, devido à sua ação de acelerar o processo de sinterização, os fundentes diminuem, conseqüentemente, as temperaturas necessárias para a queima, permitindo significativas reduções no custo com energia no processo de fabricação, fazendo com que seu uso seja sempre investigado na formulação de massas cerâmicas em escala industrial. Além disso, a melhor sinterabilidade da massa cerâmica contendo fundentes leva a uma redução na porosidade e absorção de água do produto final, aumentando, assim, a resistência mecânica desses produtos.

Comparando-se com os dados de literatura, apresentados no capitulo 2, na Tabela 2.2.3.3, pagina 39, para o dregs e grits, verifica-se que a composição química dos resíduos estudados, gerados pela indústria Jarí Celulose S.A. é equivalente aos gerados em outras unidades industriais no país, ou seja, apresenta um teor elevado de $\mathrm{CaO}$, seguido do conteúdo em $\mathrm{Na}_{2} \mathrm{O}$, relacionando-se com a composição dos reagentes contidos no licor negro durante as etapas de recuperação química do processo industrial. Esses elementos de ação fundente provêm maior formação de fase líquida, consequentemente auxiliando no fechamento da porosidade entre as partículas, conferindo aumento da densidade relativa do material sinterizado [41].

Na Figura 4.2.1, onde se representam graficamente as composições químicas dos dois resíduos, fica bem evidente sua similaridade. O dregs é um pouco mais carbonatico, possuindo, consequentemente, uma maior perda ao fogo correspondente. O grits tem um teor de sodio mais elevado, por sua relação direta na reação da cal com o liquido concentrado nesse elemento, no licor verde, na forma de carbonato. 


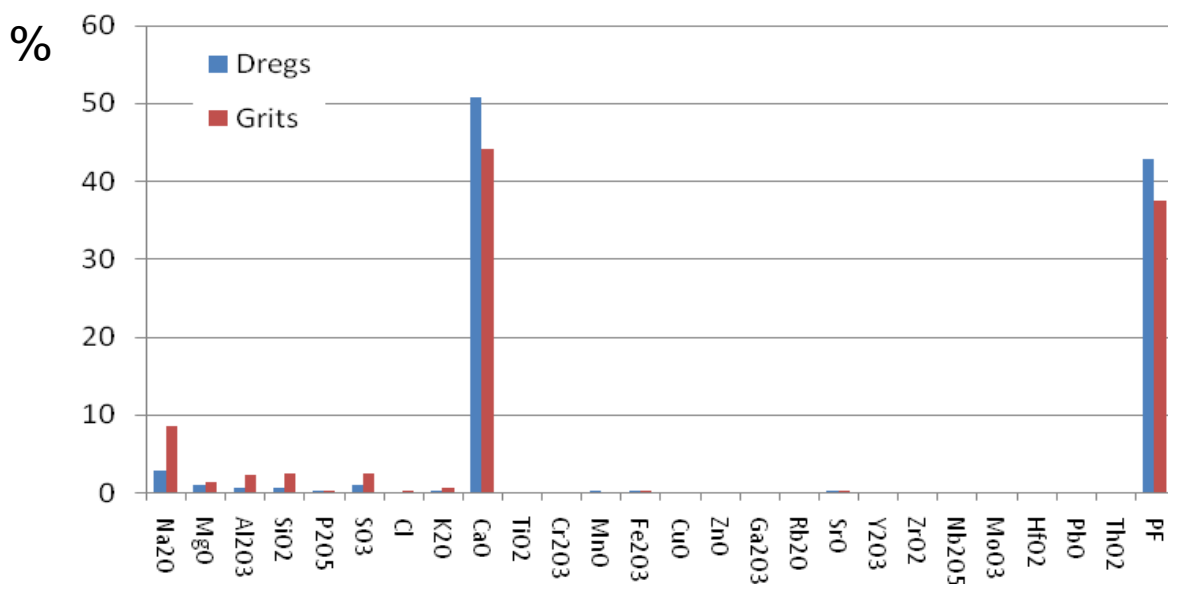

Figura 4.2.1. Comparação das composições químicas dos resíduos.

Quanto à composição química da argila, ela mostra tratar-se de um alumino-silicato com teores moderados de ferro e titânio, numa composição semelhante à caulinita, argilomineral formado pela elevada lixiviação dos cátions presentes na rocha-mãe, ocorrida provavelmente devido às condições de formação da jazida sob clima tropical bastante úmido como é típico da região amazônica. Segundo SOUZA SANTOS, P. e VIEIRA COELHO, A. C. (1988), quimicamente os argilominerais são considerados silicatos de alumínio hidratados, podendo conter certo teor de elementos alcalinos e alcalinos-terrosos, de estrutura cristalina em camadas lamelares ou de estrutura fibrosa.

A visualização gráfica do conteúdo químico da argila (Figura 4.2.2) mostra a composição de um mineral sílico-aluminoso com perda ao fogo da ordem de grandeza dos argilominerais cauliníticos. 


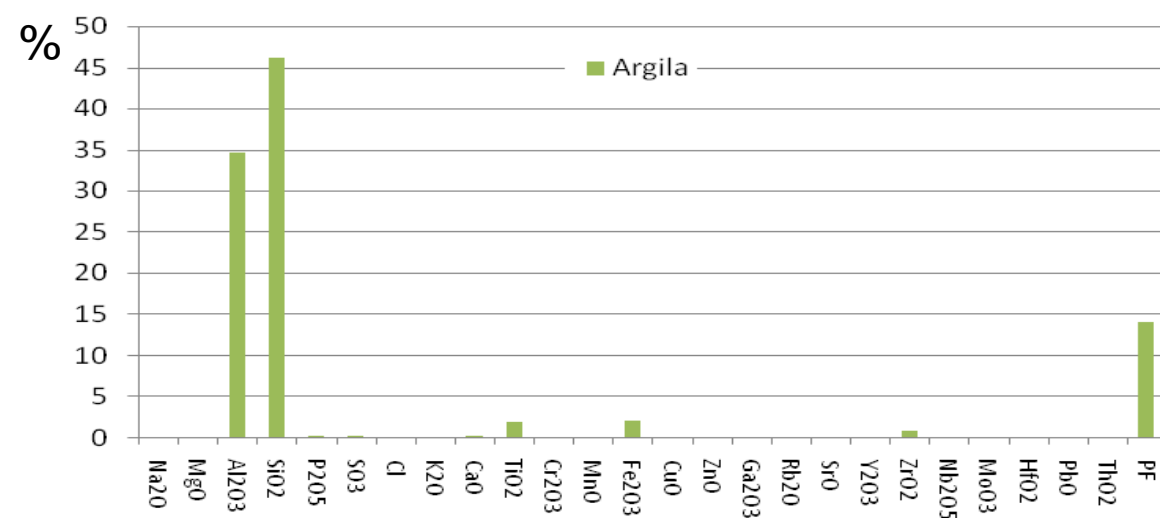

Figura 4.2.2. Representação gráfica da composição química da argila.

\subsection{PROPRIEDADES CERÂMICAS DAS FORMULAÇÕES GERADAS}

As propriedades de interesse cerâmico de resistência à flexão e retração foram medidas sobre os corpos de prova após a secagem a $110^{\circ} \mathrm{C}$. Para os corpos de prova queimados a 900 e $1000^{\circ} \mathrm{C}$, além dessas duas propriedades, foram medidas também a absorção de água, a densidade aparente e a porosidade aparente. Essas propriedades foram medidas para corpos de prova de argila pura e também para aqueles contendo resíduos.

\subsubsection{Comportamento dos corpos de prova após secagem a $110^{\circ} \mathrm{C}$}

Para os corpos de prova submetidos apenas à secagem a $110^{\circ} \mathrm{C}$, avaliou-se a resistência mecânica à flexão e a retração linear das amostras. As demais propriedades cerâmicas (absorção e porosidade) não podem ser medidas porque o 
grau de coesão incipiente das partículas (os corpos de prova foram apenas prensados) não permite a realização desses ensaios.

\subsubsection{Resistência mecânica}

Os resultados de tensão de ruptura à flexão (TRF) para as peças após secagem mostraram haver melhoria na resistência dos materiais produzidos com até 10\% de resíduos, conforme pode-se ver na Tabela 4.3.1.1.1. Os valores decresceram para a taxa de incorporação de 20\%, ficando próximo dos valores para os corpos de prova com $100 \%$ de argila apenas, voltando a apresentar leve aumento para as amostras contendo $40 \%$ de resíduos.

Tabela 4.3.1.1.1. Valores da TRF para os corpos de prova secos a $110^{\circ} \mathrm{C}$.

\begin{tabular}{|c|c|c|c|c|c|c|c|c|}
\hline \multicolumn{2}{|l|}{ formulações } & dist. cutelo $(\mathrm{cm})$ & espessura $(\mathrm{cm})$ & largura $(\mathrm{cm})$ & Forca (N) & Forca (kgf) & TRF $\left(\mathrm{kgf} / \mathrm{cm}^{2}\right)$ & Média \\
\hline \multirow[t]{5}{*}{$100 \%$ Argila } & 1 & 4,000 & 0,636 & 2,004 & 28,0 & 2,8 & 13,6 & \multirow{5}{*}{8,9} \\
\hline & 2 & 4,000 & 0,623 & 1,998 & 15,0 & 1,5 & 7,0 & \\
\hline & 3 & 4,000 & 0,632 & 1,999 & 10,0 & 1,0 & 4,8 & \\
\hline & 4 & 4,000 & 0,618 & 1,999 & 11,0 & 1,1 & 5,0 & \\
\hline & 5 & 4,000 & 0,648 & 1,999 & 28,0 & 2,8 & 14,1 & \\
\hline \multirow[t]{5}{*}{ d5g5 } & 1 & 4,000 & 0,569 & 1,989 & 10,0 & 1,0 & 3,9 & \multirow{5}{*}{12,4} \\
\hline & 2 & 4,000 & 0,564 & 1,990 & 63,0 & 6,3 & 23,9 & \\
\hline & 3 & 4,000 & 0,596 & 1,993 & 55,0 & 5,5 & 23,4 & \\
\hline & 4 & 4,000 & \multirow[t]{2}{*}{0,545} & 1,991 & 30,0 & 3,0 & 10,6 & \\
\hline & 5 & 4,000 & & 1,994 & 20,0 & 2,0 & - & \\
\hline \multirow[t]{5}{*}{ d10g10 } & 1 & 4,000 & 0,699 & 2,001 & 16,0 & 1,6 & 9,4 & \multirow{5}{*}{8,7} \\
\hline & 2 & 4,000 & 0,696 & 2,003 & 14,0 & 1,4 & 8,2 & \\
\hline & 3 & 4,000 & 0,680 & 2,008 & 15,0 & 1,5 & 8,4 & \\
\hline & 4 & 4,000 & 0,696 & 2,000 & 15,0 & 1,5 & 8,7 & \\
\hline & 5 & 4,000 & 0,684 & 2,002 & 16,0 & 1,6 & 9,0 & \\
\hline \multirow[t]{5}{*}{ d20g20 } & 1 & 4,000 & 0,689 & 1,998 & 13,0 & 1,3 & 7,4 & \multirow{5}{*}{10,1} \\
\hline & 2 & 4,000 & 0,675 & & & & & \\
\hline & 3 & 4,000 & 0,691 & 1,999 & 31,0 & 3,1 & 17,8 & \\
\hline & 4 & 4,000 & 0,681 & 2,004 & 14,0 & 1,4 & 7,8 & \\
\hline & 5 & 4,000 & 0,682 & 1,998 & 13,0 & 1,3 & 7,2 & \\
\hline
\end{tabular}


Os resultados médios das variações da TRF são mostrados graficamente na Figura

\subsubsection{1.}

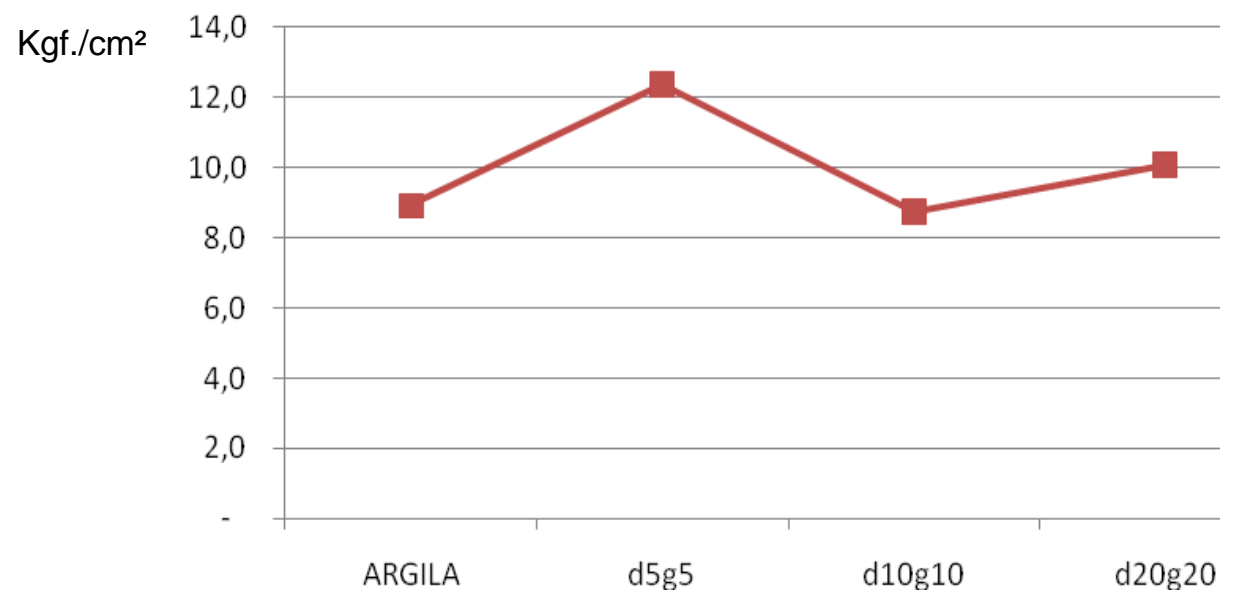

Figura 4.3.1.1.1 - Variação do valor da TRF $\left(\mathrm{Kgf} / \mathrm{cm}^{2}\right)$ com o teor de incorporação dos resíduos na massa cerâmica para as formulações a verde (d=dregs, $g=$ grits).

\subsubsection{Retração linear}

A retração linear após secagem mostrou o maior valor para a composição contendo $10 \%$ de resíduos ( $5 \%$ dregs $+5 \%$ grits). No entanto, não foi identificada uma tendência linear de variação, uma vez que teores de resíduos maiores do que $10 \%$ diminuíram o valor da retração linear, colocando-os em níveis abaixo da retração registrada com o emprego único da argila (Figura 4.3.1.2.1.). 


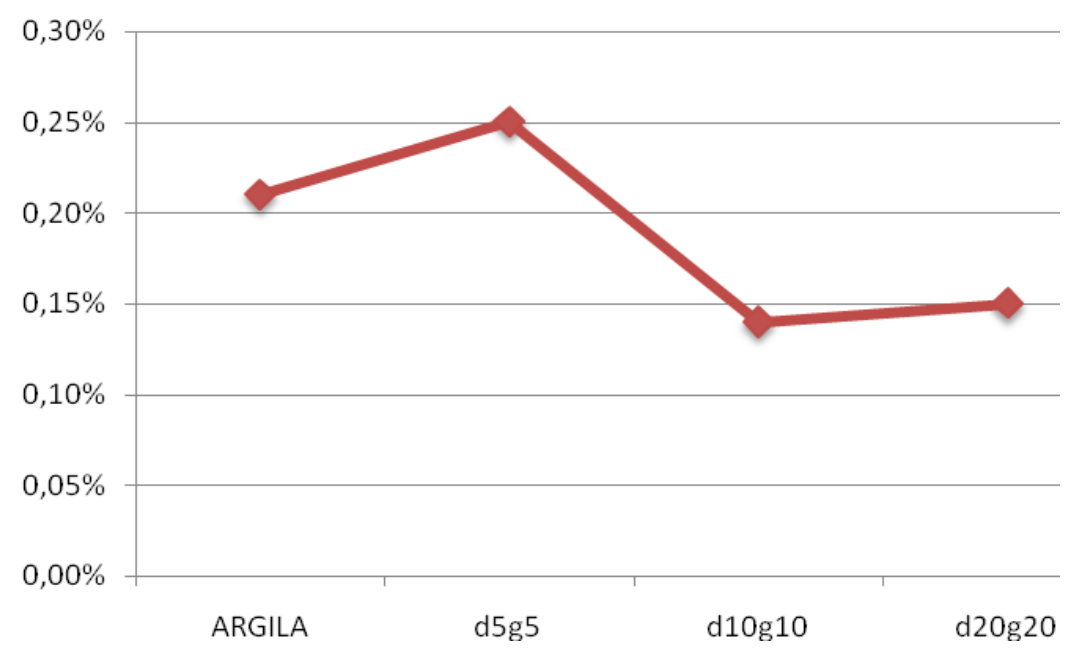

Figura 4.3.1.2.1. Evolução da retração linear após secagem com a in corporação dos resíduos (d=dregs, g=grits).

Associando-se este resultado com aquele da resistência mecânica à flexão, verificase que a maior retração se deu com a composição que apresentou maior resistência mecânica. Esse fato pode ser explicado pela possível maior reação entre as fases presentes.

\subsubsection{Comportamento após a queima dos materiais}

Os corpos de prova que foram queimados às temperaturas finais de 900 e $1000^{\circ} \mathrm{C}$, temperaturas freqüentemente atingidas pelas olarias na produção de cerâmica vermelha (telhas e tijolos para a Construção Civil) e tiveram avaliados suas propriedades cerâmicas de absorção de água, porosidade aparente, massa específica aparente, resistência mecânica à flexão (TRF) e retração linear. Os corpos de prova contendo $40 \%$ de resíduos, $20 \%$ de dregs e $20 \%$ de grits, por sua vez, sofreram decomposição nas duas temperaturas de queima, portanto não foi possível produzir peças cerâmicas com esse nível de formulação para os demais ensaios. 


\subsubsection{Absorção de água após queima}

Os resultados obtidos para a absorção de água mostraram uma queda em seu valor para a composição contendo $10 \%$ de resíduos, sendo menor a absorção para a queima a $1000^{\circ} \mathrm{C}$ do que aquela para $900^{\circ} \mathrm{C}$ (Figura 4.3.2.1.1).

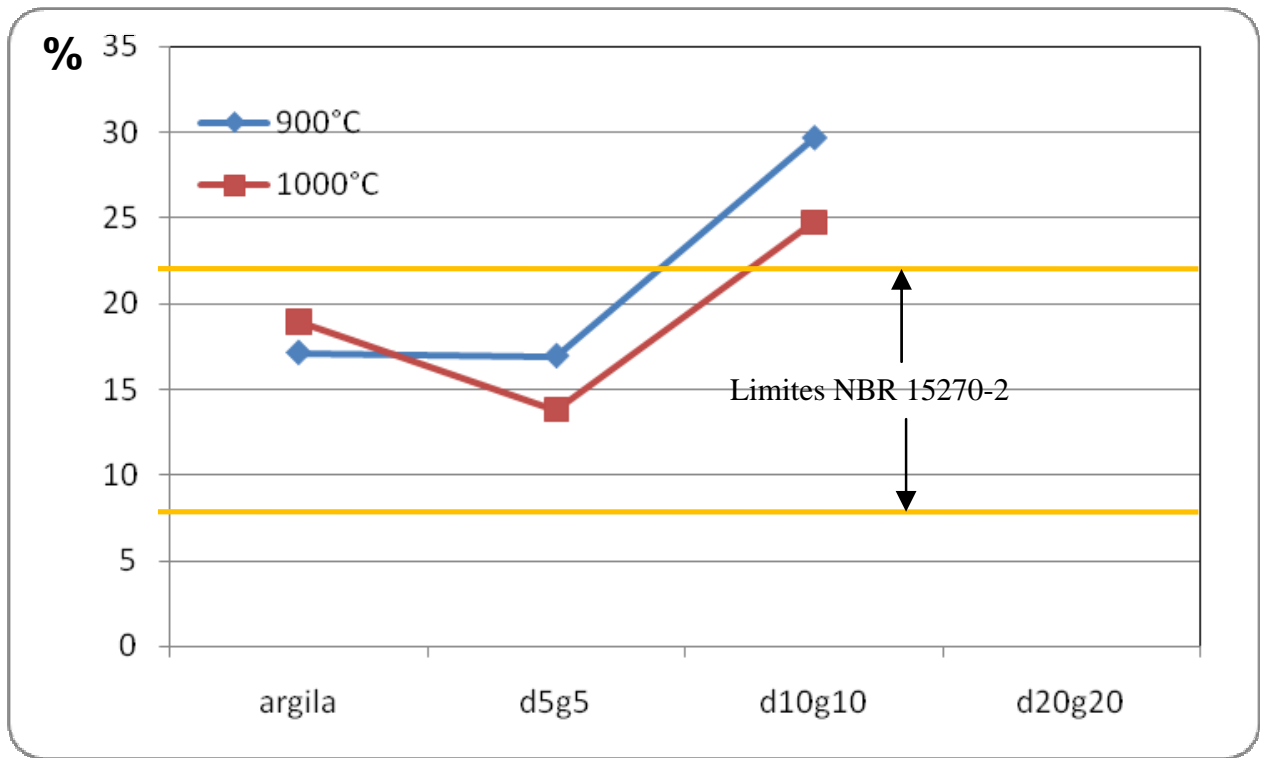

Figura 4.3.2.1.1 - Absorção de água (\%) com a composição e a temperatura de queima, com a indicação dos limites para blocos cerâ micos estruturais prescritos pela norma ABNT15270-2.

Com relação a propriedade de absorção de água pode-se observar que para queima a $900^{\circ} \mathrm{C}$ não houve contribuição no acréscimo do resíduo a massa. Entretanto, a $1000^{\circ} \mathrm{C}$, o acréscimo de $10 \%$ dos resíduos, contribui para um decréscimo na taxa de absorção de água de níveis da ordem de $19 \%$ para níveis inferiores a 14\%, isto é, com $10 \%$ dos resíduos registrou-se uma redução de $26 \%$ nos índices de absorção de água. 
É bastante notório que o aumento da quantidade de resíduo na mistura, acima de $10 \%$, afeta substancialmente o comportamento do produto queimado em termos de absorção de água elevando-os em quase duas vezes.

De acordo com a NBR 15270-2 (ABNT, 2005), que fixa os requisitos dimensionais, físicos e mecânicos exigíveis de blocos cerâmicos estruturais a serem utilizados em obras de alvenaria, os índices de absorção de água não devem ser inferiores a 8\% nem superiores a 22\%. Assim, apenas a composição contendo $10 \%$ de resíduo parece adequar-se à fabricação de produtos cerâmicos estruturais (14 e 17\% de absorção, respectivamente para queimas a 1000 e $900^{\circ} \mathrm{C}$ ). Com $20 \%$ de resíduos verifica-se um aumento significativo no índice de absorção de água, atingindo os valores de 24 e $30 \%$ de absorção (para queimas a 1000 e $900^{\circ} \mathrm{C}$, respectivamente).

\subsubsection{Massa especifica aparente}

Os valores obtidos nos ensaios de determinação da massa específica aparente variaram de modo similar para as duas temperaturas de queima, como se pode observar na Figura 4.3.2.2.1. Para a queima a $1000^{\circ} \mathrm{C}$, obteve-se um valor um pouco superior da massa específica aparente para o corpo de prova contendo adição de $10 \%$ de resíduos $(1,90 \mathrm{~g} / \mathrm{cm} 3)$, relativamente ao registrado para a temperatura de $900^{\circ} \mathrm{C}(1,87 \mathrm{~g} / \mathrm{cm} 3)$

A partir de $20 \%$ de resíduos a densidade teve queda significativa, provavelmente devido a maior perda de massa devido a composicao dos constituintes desses resíduos. 


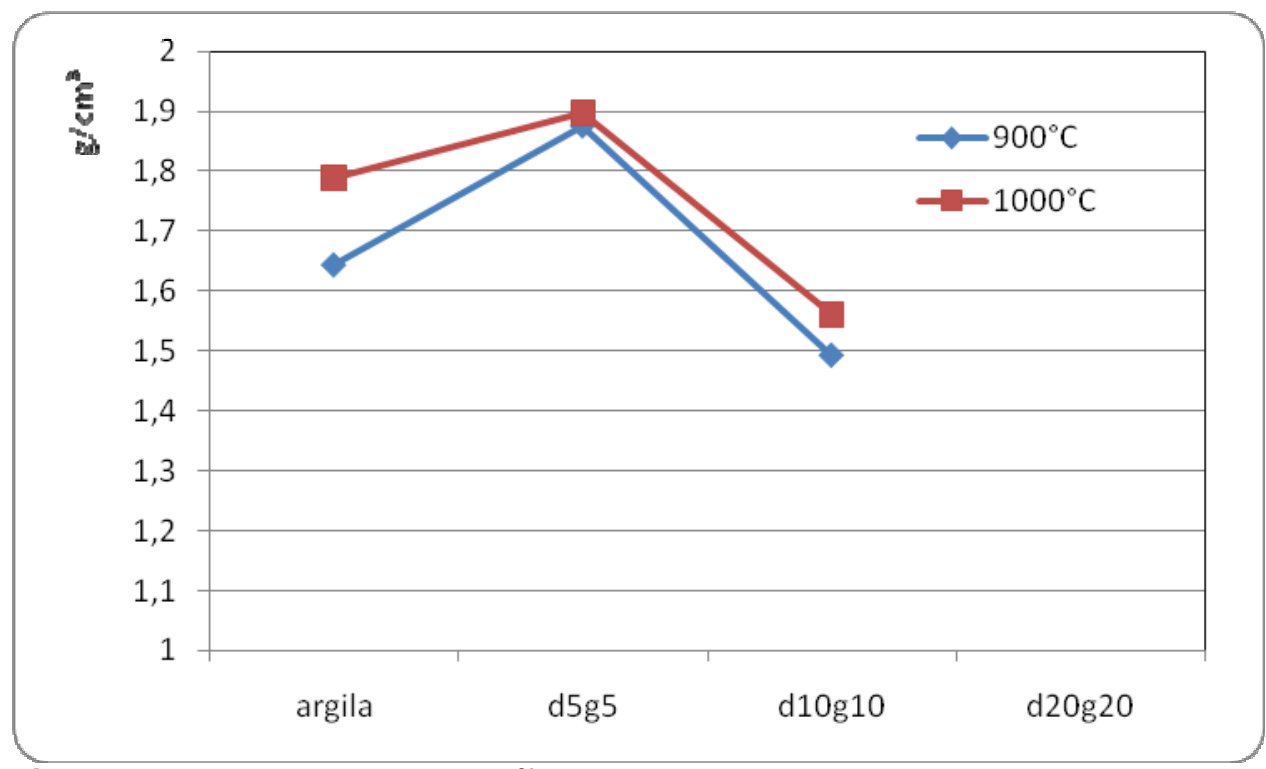

Figura 4.3.2.2.1 - Massas específicas aparentes dos corpos de prova comtendo e não resíduos (d=dregs, $\mathrm{g}=$ grits).

\subsubsection{Porosidade aparente}

A porosidade aparente dos corpos de prova variaram entre os valores de 25 a $45 \%$. A menor porosidade registrada foi para a composição de $10 \%$ de resíduos, queimada a $1000^{\circ} \mathrm{C}$, como pode ser visto no gráfico da Figura 4.3.2.3.1.

De acordo com LENGLER (2006) "a porosidade de revestimentos cerâmicos está intimamente associada à formação de gases na queima e deficiências na eliminação dos espaços intergranulares provenientes de sua conformação." A diminuição da porosidade se relaciona intimamente com a formação de fases vítreas favorecidas pela presença de fundentes que auxiliam a sinterização mais rápida e a menores temperaturas. 


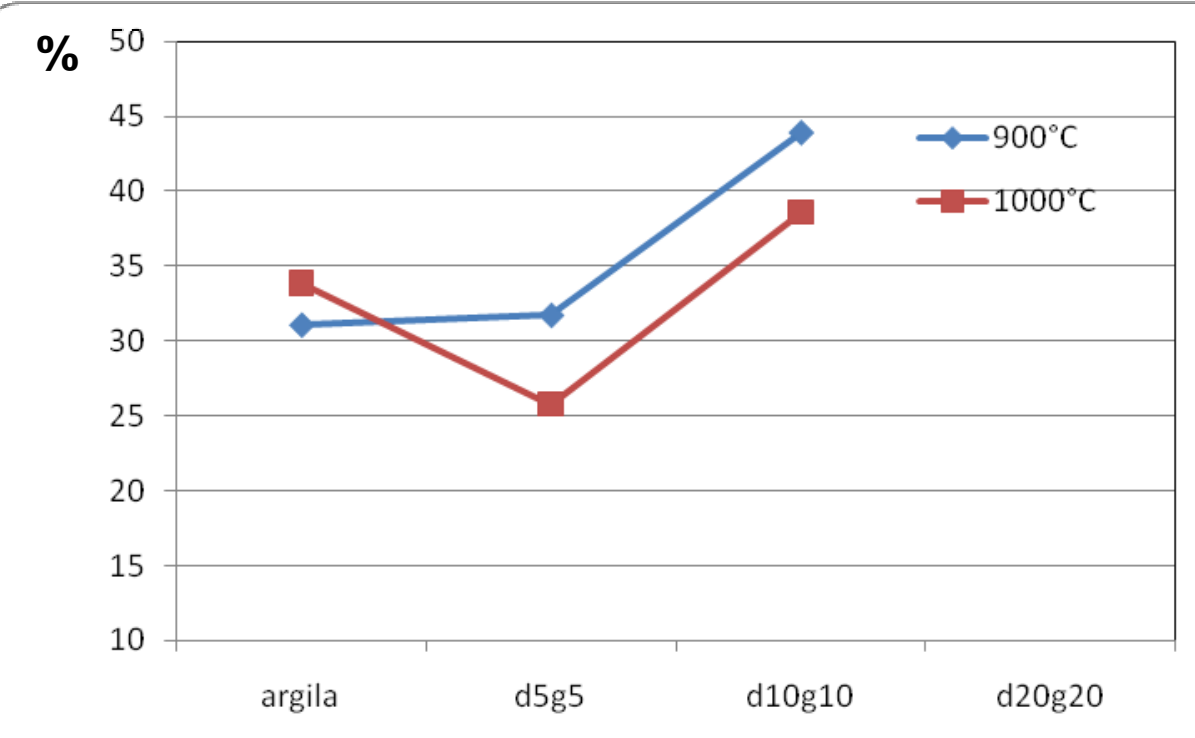

Figura 4.3.2.3.1 - Variação da porosidade com a temperatura de queima e composição dos corpos de prova (d=dregs, $g=$ =grits).

SOUZA SANTOS (1975), em seu célebre compêndio sobre argilas, apresentou resultados de porosidade aparente para uma série de argilas brasileiras queimadas à temperatura de $950^{\circ} \mathrm{C}$, cujos resultados são apresentados na Figura 4.3.2.3.2.
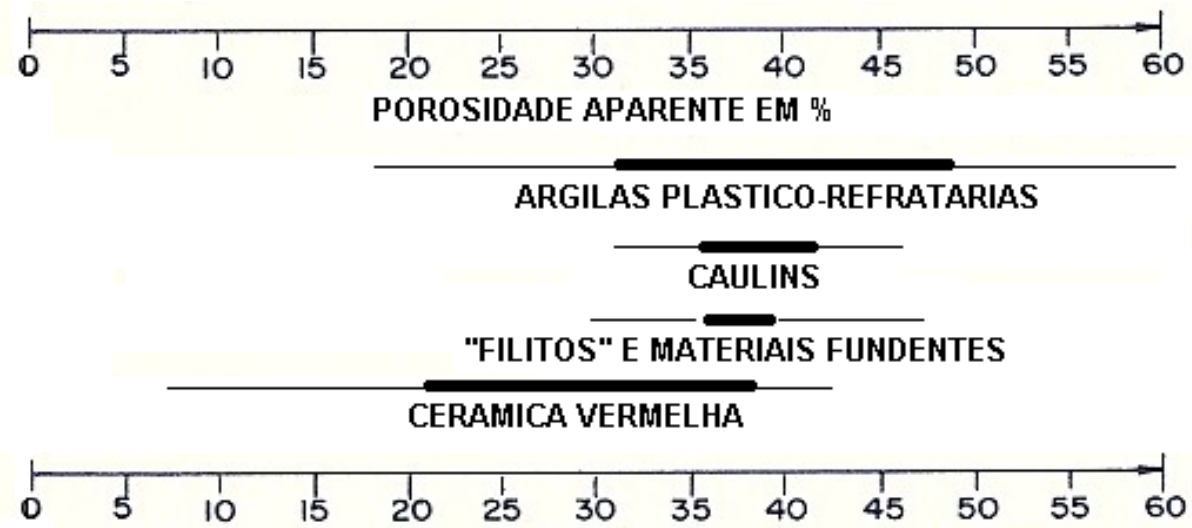

Figura 4.3.2.3.2 - Faixas de variação da porosidade aparente de diversas argilas brasileiras após queima a $950^{\circ} \mathrm{C}$, adaptado de SOUZA SANTOS, P. (1975). 
Comparando-se os valores de porosidade obtidos neste trabalho com aqueles reportados pelo autor citado, observa-se que contendo ou não resíduos, os materiais estudados podem ser muito bem situados na faixa das argilas para cerâmica vermelha, com a possibilidade, talvez, de enquadramento nos resultados das argilas plástico-refratárias.

A menor porosidade com $10 \%$ de resíduos, queimada a $1000^{\circ} \mathrm{C}$, certamente relaciona-se à maior sinterização proporcionada pela temperatura mais elevada, mas também devido à presença de elementos de ação fundente em sua composição, provenientes dos resíduos.

\subsubsection{Resistência mecânica}

A resistência mecânica à flexão das formulações mostrou que para ambas as temperaturas de queima, a mistura dos resíduos na proporção de 10\% aumentou consideravelmente a resistência do material produzido, um pouco mais acentuadamente para $1000^{\circ} \mathrm{C}$, quando a resistência variou de $34 \mathrm{Kgf} / \mathrm{cm}^{2}$ para o material constituído exclusivamente de argila, a $52 \mathrm{Kgf} / \mathrm{cm}^{2}$, para o material com a incorporação de $5 \%$ de dregs e $5 \%$ de grits (Figura 4.3.2.4.1),

Com o aumento na proporção dos residuos, constituintes que apresentam uma perda ao fogo sensivelmente maior, a resistência mecânica decaiu sensivelmente. Isso demonstra que com até $10 \%$ as reações entre os materiais contribuíram para a formação de novas fases com certo equilíbrio, rompido quando se ultrapassou esse limite. 


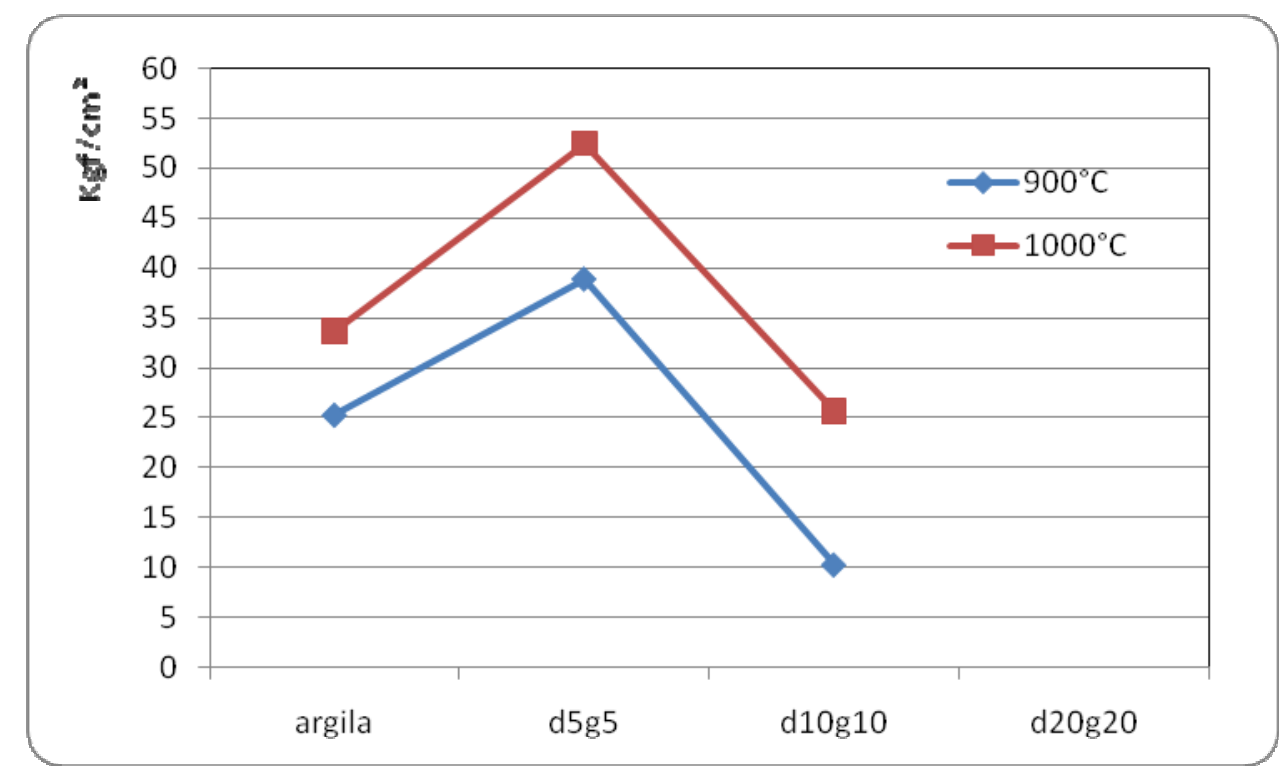

Figura 4.3.2.4.1 - Evoluções dos valores de TRF com a incorporação dos resíduos a duas temperaturas de queima (d=dregs, $g=g r i t s)$.

\subsubsection{Retração linear}

A retração linear após a queima foi mais acentuada para as amostras submetidas à queima a $1000^{\circ} \mathrm{C}$ (Figura 4.3.2.5.1).

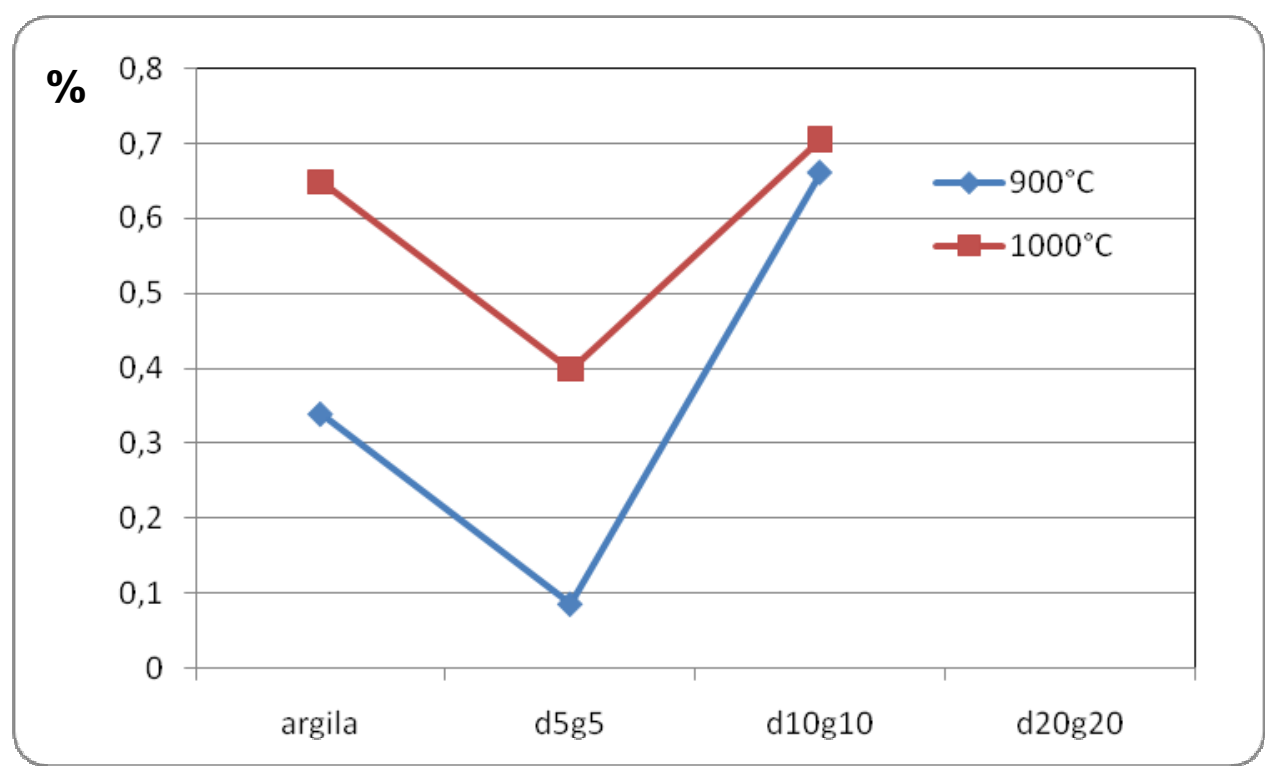

Figura 4.3.2.5.1 - Retração linear dos corpos de prova a 900 e $1000^{\circ} \mathrm{C}$. 


\subsubsection{Interpretação geral dos ensaios cerâmicos}

Os resultados obtidos quanto às propriedades cerâmicas dos materiais produzidos ao longo dos trabalhos estão sumarizados na Tabela 4.3.3.1.

Tabela 4.3.3.1. Quadro resumo das propriedades cerâmicas a diferentes temperaturas e condições de mistura dos materiais.

\begin{tabular}{|c|c|c|c|c|c|c|}
\hline $\begin{array}{c}\text { Temp. } \\
\left({ }^{\circ} \mathrm{C}\right)\end{array}$ & Composição & $\begin{array}{l}\text { AA } \\
(96)\end{array}$ & $\begin{array}{l}\mathbf{P A} \\
(4)\end{array}$ & $\begin{array}{l}\mathrm{RL} \\
(0,4)\end{array}$ & $\begin{array}{c}\text { MEA } \\
\text { (㣚) }\end{array}$ & $\begin{array}{c}\text { TRF } \\
\text { (MPa) }\end{array}$ \\
\hline \multirow{4}{*}{110} & Só argila & & & 0,21 & & 7,61 \\
\hline & 0565 & & & 0,25 & & 15,45 \\
\hline & 010010 & & & 0,15 & & 8,72 \\
\hline & 020020 & & & 0,15 & & 7,48 \\
\hline \multirow{4}{*}{900} & Só argila & 17,12 & 31,12 & 0,34 & 1,64 & 25,28 \\
\hline & 0505 & 16,93 & 31,76 & 0,09 & 1,87 & 38,91 \\
\hline & 010010 & 29,65 & 43,89 & 0,66 & 1,49 & 10,26 \\
\hline & 020020 & \multicolumn{5}{|c|}{ houte decomposcabo dos corpos de prowa apos a quema } \\
\hline \multirow{4}{*}{1000} & Só argila & 19,94 & 33,87 & 0,65 & 1,79 & 33,73 \\
\hline & 0565 & 15,38 & 25,78 & 0,51 & 1,89 & 52,46 \\
\hline & 010010 & 24,74 & 38,59 & 0,70 & 1,56 & 30,78 \\
\hline & 020020 & \multicolumn{5}{|c|}{ houve decomposiçäo dos corpos de prowa apos a queima } \\
\hline
\end{tabular}

Exceto para a incorporação de $40 \%$ de resíduos na massa, os quais não se mantiveram consistentes mesmo nas temperaturas de queima, os resultados obtidos para as demais proporções (10\% e $20 \%$ ), resultaram em possibilidades de uso dos resíduos para produção de produtos cerâmicos estruturais. Deve-se destacar que dentre os teores de adições investigados, o teor de $10 \%$ da massa total na forma de resíduos, dosados igualmente entre os dois resíduos, resultou no melhor balanço de propriedades.

Comparando-se esses resultados com aqueles reportados na literatura técnica relativa ao estudo de incorporação de outros tipos de resíduos industriais a massas 
cerâmicas, foram encontrados uma série deles, sendo que alguns apresentam, inclusive, efeitos menos favoráveis quando comparados com os resultados obtidos neste trabalho. XAVIER, G.C. et al (2003) apresentam resultados de absorção de água para materiais queimados a 850 e $950^{\circ} \mathrm{C}$ não inferiores a $20 \%$ para incorporação de resíduos da produção de serrarias de mármores. Nesse mesmo trabalho, os resultados de porosidade aparente mostraram-se superiores a $35 \%$ nas faixas de temperatura mencionadas.

No gráfico da Figura 4.3.3.1 são apresentados resultados de ensaios de absorção de água de blocos produzidos por indústrias de cerâmica vermelha divulgados no trabalho de SOARES et al. (2003).

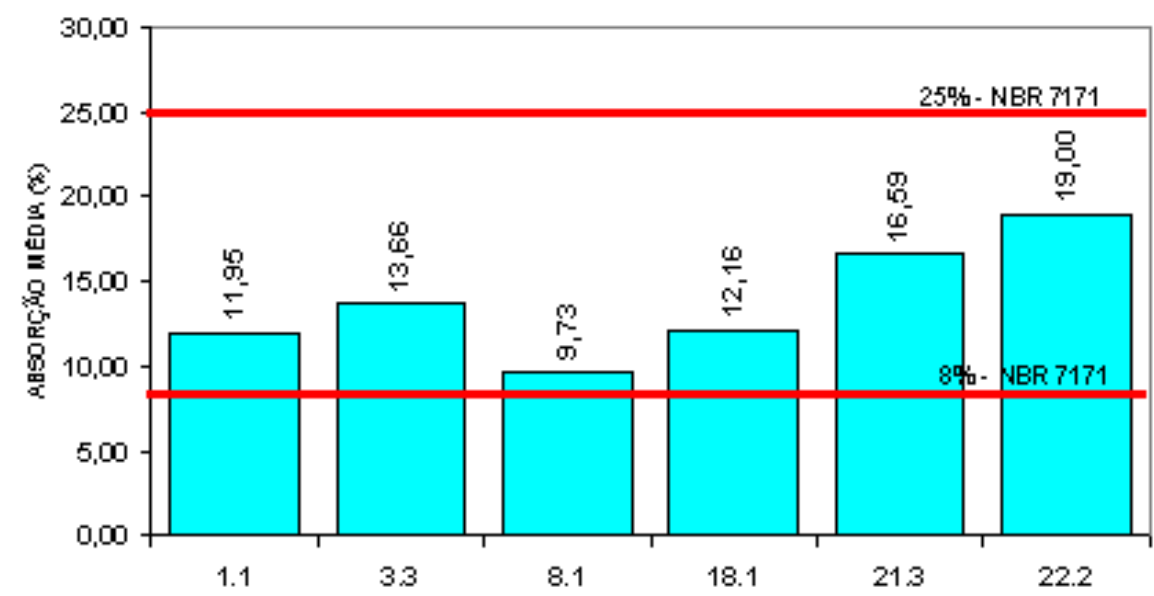

Figura 4.3.3.1 - Resultados para a absorção de água de blocos cerâmicos, segundo SOARES et al (2003).

Como pode ser observado, quando se compara os resultados de absorção de água desses blocos comerciais com os limites máximos e mínimos prescritos pela norma ABNT NBR 7171, os resultados obtidos neste trabalho, empregando dregs e grits em teor total de $10 \%$, situa-se também dentro dos limites. Deve ser destacado que a norma brasileira referida no estudo citado (NBR7171) foi substituída pela norma ABNT NBR 15270-2, já citada no item 4.3.2.1, em 2005, sendo que os limites 
mínimo e máximo de absorção de água nessa nova edição da norma são, respectivamente, de 8 e $22 \%$.

Com relação à tensão de ruptura à flexão (TRF), SOARES et al (2003a) estudaram a incorporação de resíduo da indústria fumageira em massas para produção de cerâmica vermelha, obtendo valores compatíveis com aqueles obtidos no estudo aqui apresentado. Os autores estudaram adições de resíduos de 5, 10 e 15\%, em massa, queimando os materiais em temperaturas de 900,950 e $1050^{\circ} \mathrm{C}$. Os materiais assim obtidos apresentaram TRF's na faixa de 20 a $30 \mathrm{MPa}$, compatíveis, assim (e mesmo inferiores), aos resultados obtidos neste trabalho empregando dregs e grits como adições.

As demais propriedades de interesse cerâmico observadas, tais como massa específica aparente e porosidade aparente, medidas para as misturas preparadas neste estudo, indicam faixas de valores compatíveis com a qualidade requerida para produtos estruturais de cerâmica vermelha (tais como blocos), especialmente para a porcentagem de adição de 10\% (dregs + grits).

\subsection{DIFRAÇÃO DE RAIOS X}

Através da difração de raios $X$ foi possível identificar bem algumas fases cristalinas constituintes dos materiais estudados. 


\subsubsection{Argila}

A difração de raios $X$ da argila como recebida teve como resultado a curva da Figura 4.4.1.1. Tendo como base os padrões difratométricos de fases individuais disponibilizados pelo ICDD - International Centre for Diffraction Data - foi possível identificar na composição da argila as fases quartzo, caulinita e muscovita. A primeira, com o pico característico de maior intensidade ocorrendo ao ângulo $2 \theta$ de $26,65^{\circ}$, mas aparecendo também, com intensidades menores, os picos a $20,85^{\circ} \mathrm{e}$ 50,14 (Ficha 33-1161 do ICDD).

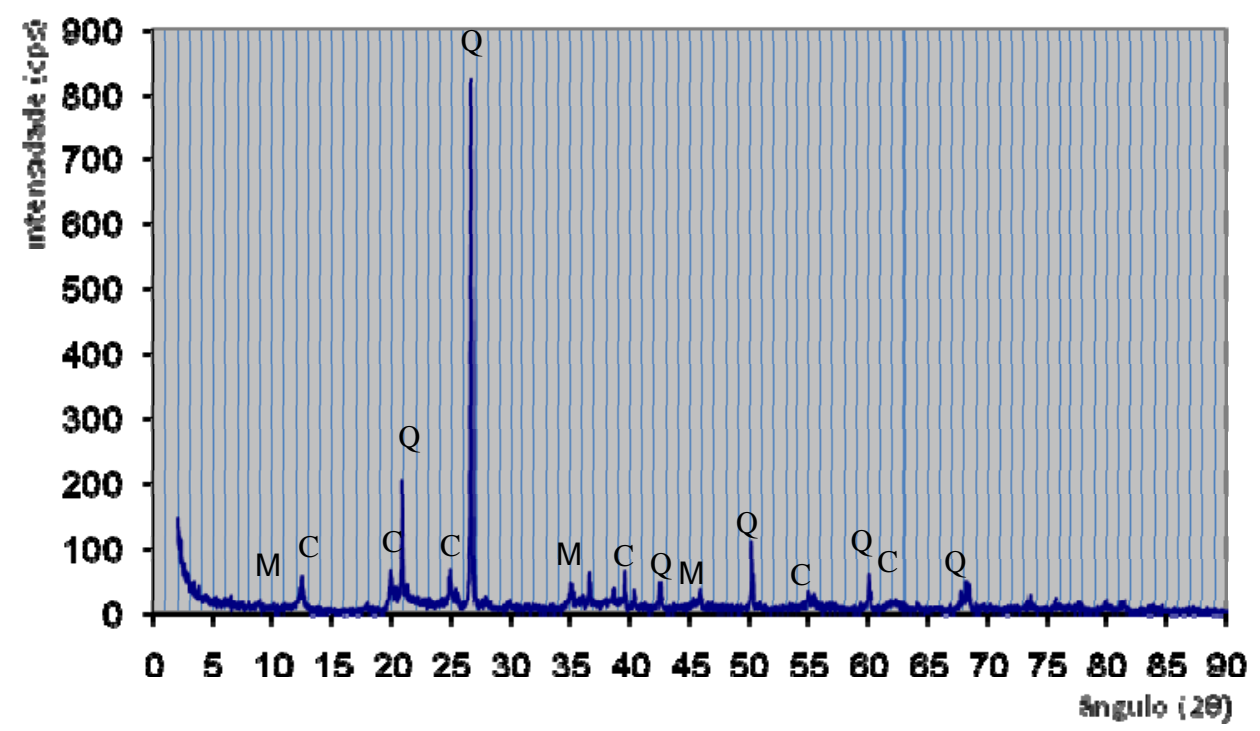

Figura 4.4.1.1 - Curva de difração de raios $X$ da argila crua com identificação das fases cristalinas quartzo (Q), caulinita (C) e muscovita (M).

As presença da caulinita pode ser melhor observada reduzindo-se os campos do gráfico apresentado anteriormente, como se mostra na Figura 4.4.1.2 e na Figura 4.4.1.3. 
A caulinita é bem visivel aos ângulos $2 \theta$ igual a $12,334^{\circ}$, seguido dos ângulos $2 \theta$ $20,323^{\circ}$ e $24,857^{\circ}$, correspondente aos valores mais significativos de intensidades indicados para o mineral (Ficha ICDD 14-0164).

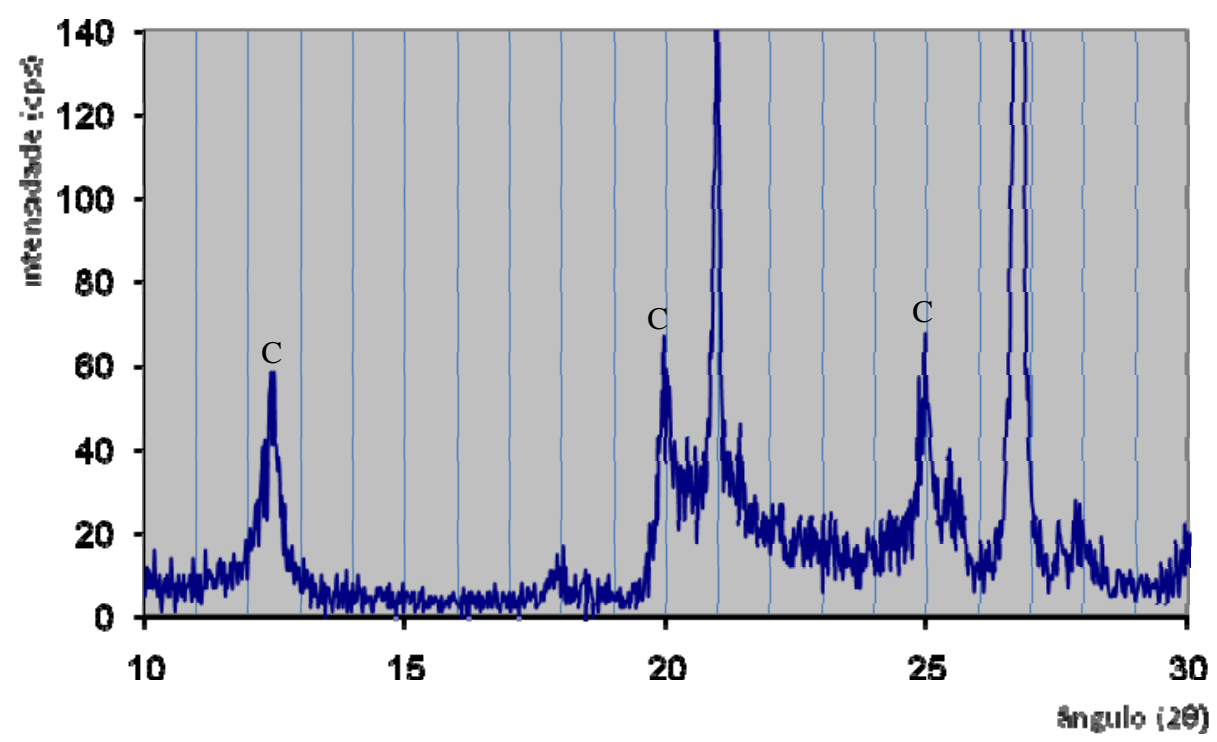

Figura 4.4.1.2 - Curva de difração de raios $X$ da argila crua com indicação dos picos característicos da fase caulinita (C).

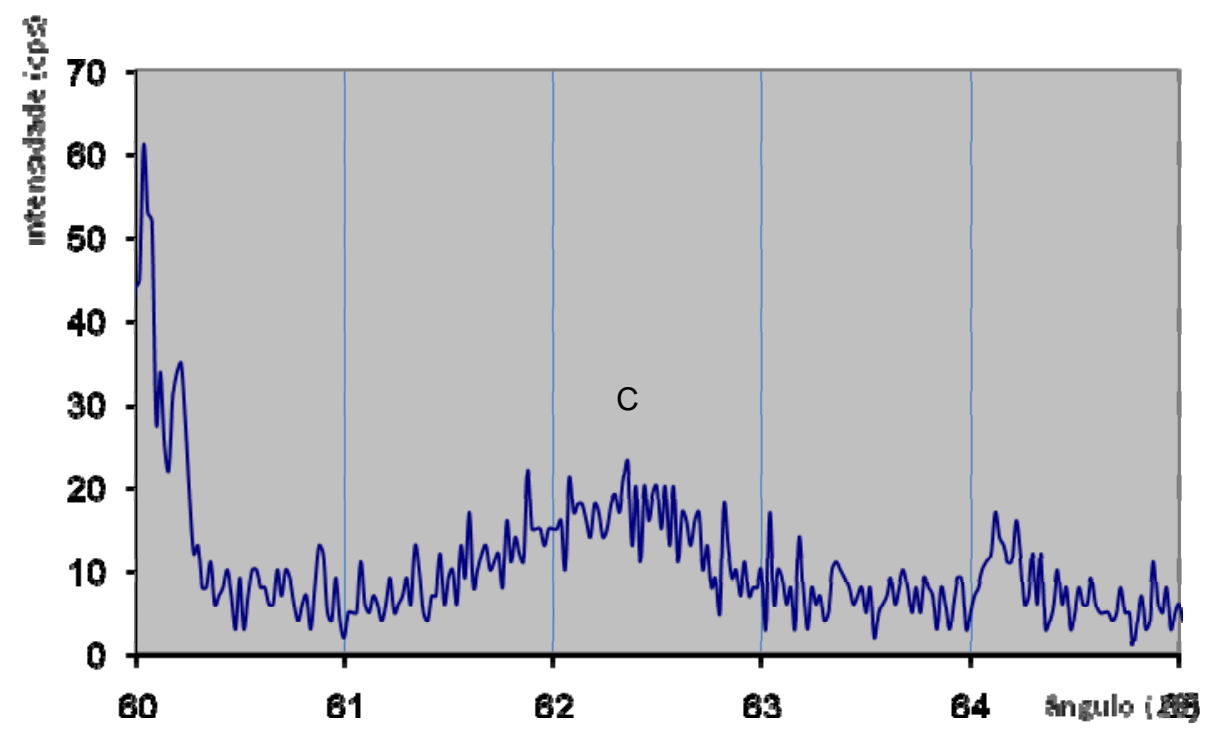

Figura 4.4.1.3 - Curva de difração de raios $X$ da argila crua com destaque para a identficação do pico de caulinita ao ângulo $2 \theta=62,304^{\circ}$. 
Ainda, ao ângulo $2 \theta$ igual a $62,304^{\circ}$, referido na Ficha $14-0164$ como de intensidade de $90 \%$, pode se observar a presença do mineral caulinita, necessitando para tanto um maior fechamento do gráfico, como mostrado na Figura 4.4.1.3.

Por sua vez, a muscovita (Ficha ICDD 34-0175), foi identificada na amostra de argila por apresentar picos aos ângulos $2 \theta$ de $8,853^{\circ}, 24,333^{\circ}$ e $35,108^{\circ}$ (Figura 4.4.1.4).

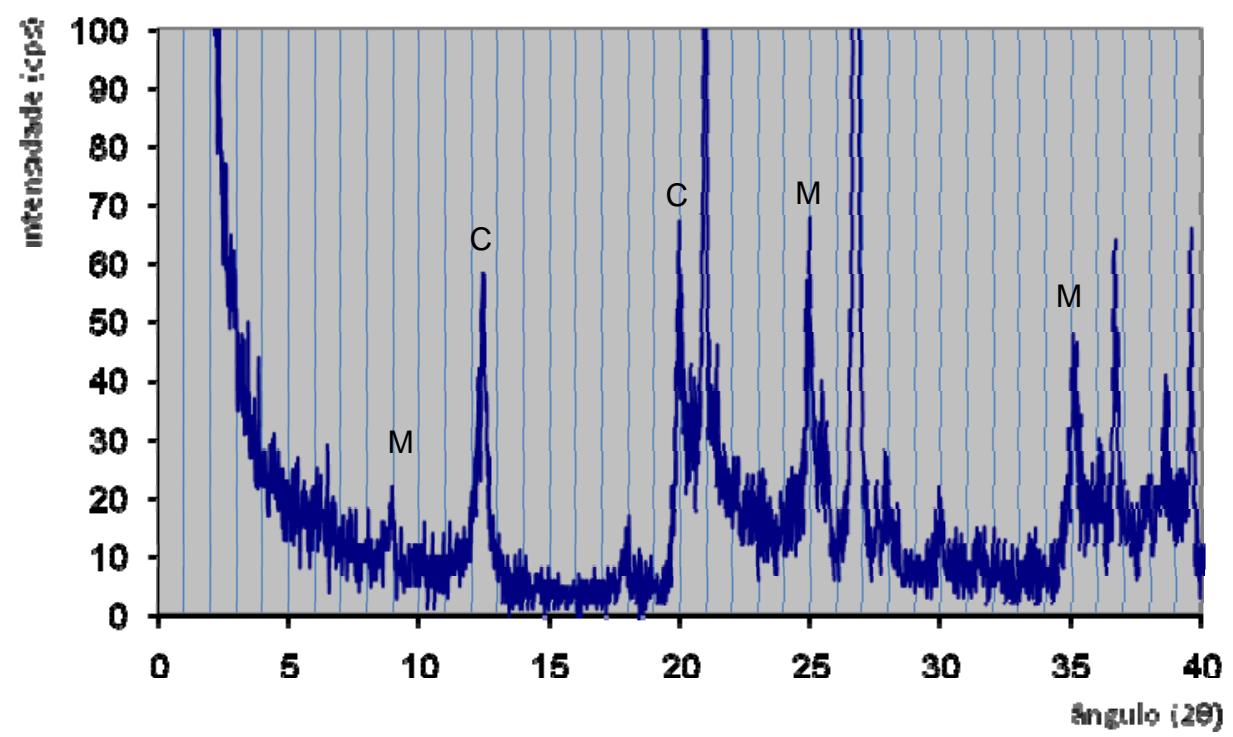

Figura 4.4.1.4 - Curva de difração de raios $X$ da argila crua com destaque para as fases muscovita (M) e caulinita (C).

A argila pura queimada a $1.000^{\circ} \mathrm{C}$ apresentou o resultado de difração de raios $X$ mostrado na Figura 4.4.1.5. Comparativamente à curva produzida pela argila crua (Figura 4.4.1.1), destaca-se de imediato a ausência da fase cristalina caulinita. $O$ tratamento térmico provoca a transformação da caulinita em metacaulinita, fase amorfa fruto da desidroxilação do argilomineral, fato também discutido por MAIA 
(2007). Como já observado e comentado por VIEIRA (2007), já "a partir de $600^{\circ} \mathrm{C}$, a caulinita não é mais detectada, devido à formação, da fase amorfa, metacaulinita." O mesmo autor comenta que em torno de $1000^{\circ} \mathrm{C}$, a metacaulinita começa a transformar-se em mulita, evidenciado a $2 \theta=33,228^{\circ}$ como indicado no gráfico.

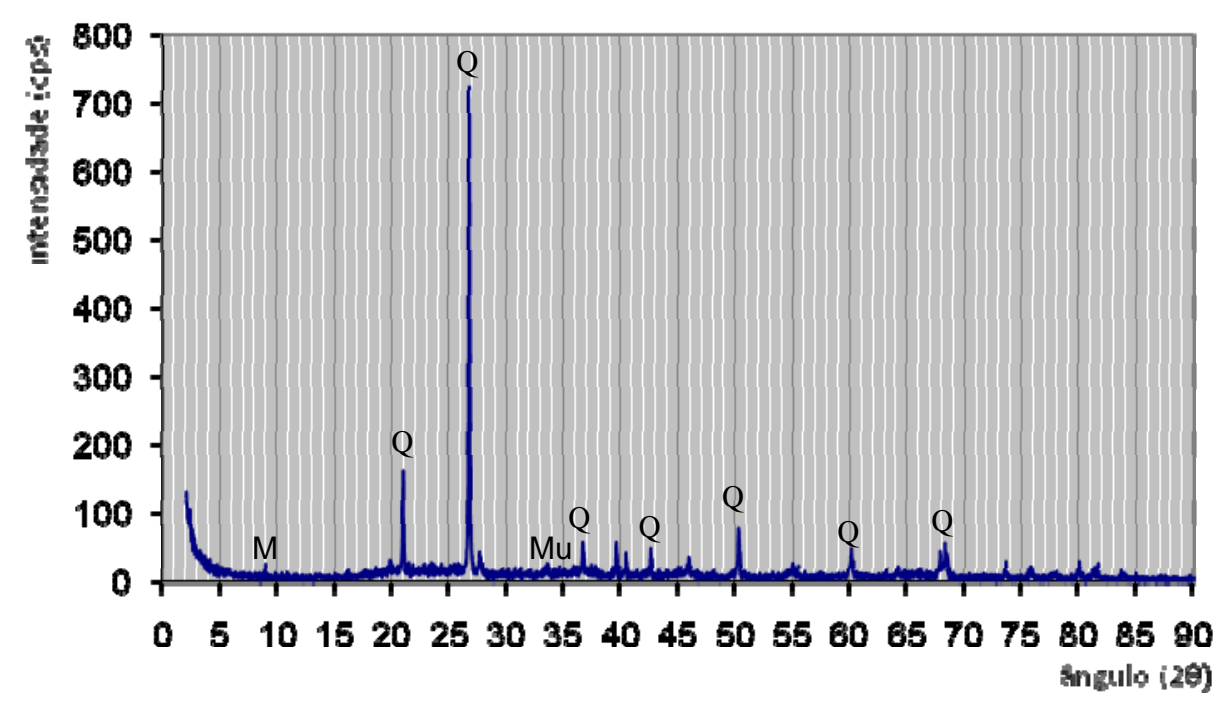

Figura 4.4.1.5 - $\quad$ Curva de difração de raios $X$ da argila queimada a $1.000^{\circ} \mathrm{C}$. Destaques para o desaparecimento dos picos tipicos da caulinita, permanencia dos picos do quartzo (Q) e o provavel aparecimento inicial da mulita $(\mathrm{Mu})$.

Ampliando o difratograma para faixas de ângulos $2 \theta$ da mulita, pode-se encontrar evidência do início da formação dessa fase, em ângulos $2 \theta$ iguais a 25,971 $; 26,267^{\circ}$ e 40,874 (Figura 4.4.1.6), de acordo com a Ficha ICDD n 15-0776. 


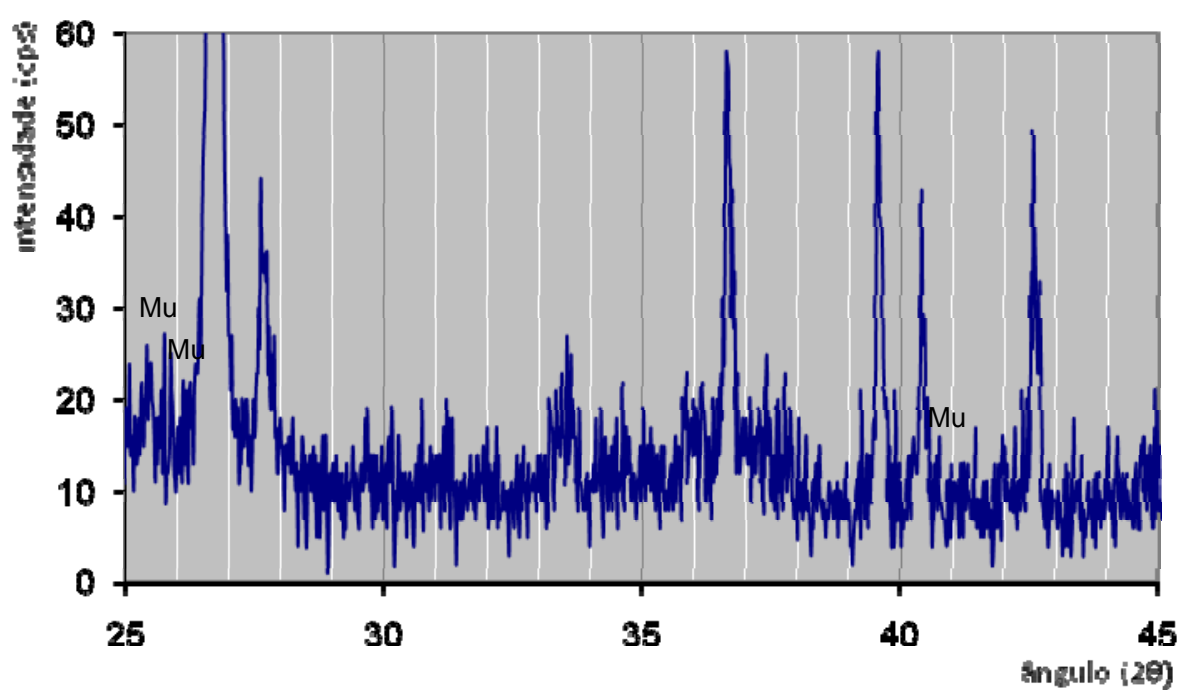

Figura 4.4.1.6 - Curva de difração de raios $X$ parcial da argila queimada a $1.000^{\circ} \mathrm{C}$, destacando-se presença de fases mulita (Mu) ainda incipiente.

\subsubsection{Dregs}

O difratograma do residuo dregs é apresentado na Figura 4.4.2.1. Observa-se que a principal fase cristalina destacada no difratograma de raios $X$ do dregs, tendo como referência a Ficha ICDD 83-0578, é a do carbonato de cálcio. Os principais ângulos $2 \theta$ foram: $23,060^{\circ} ; 29,410^{\circ} ; 35,976^{\circ} ; 39,410^{\circ} ; 43,167^{\circ} ; 47,527^{\circ}$ e $48,520^{\circ}$.

É notório observar-se no dregs a inexistência de outras fases cristalinas. Aparentemente o resíduo não apresenta contaminações expressivas de materiais inorgânicos (pelo menos as que apresentem cristalinidade). 


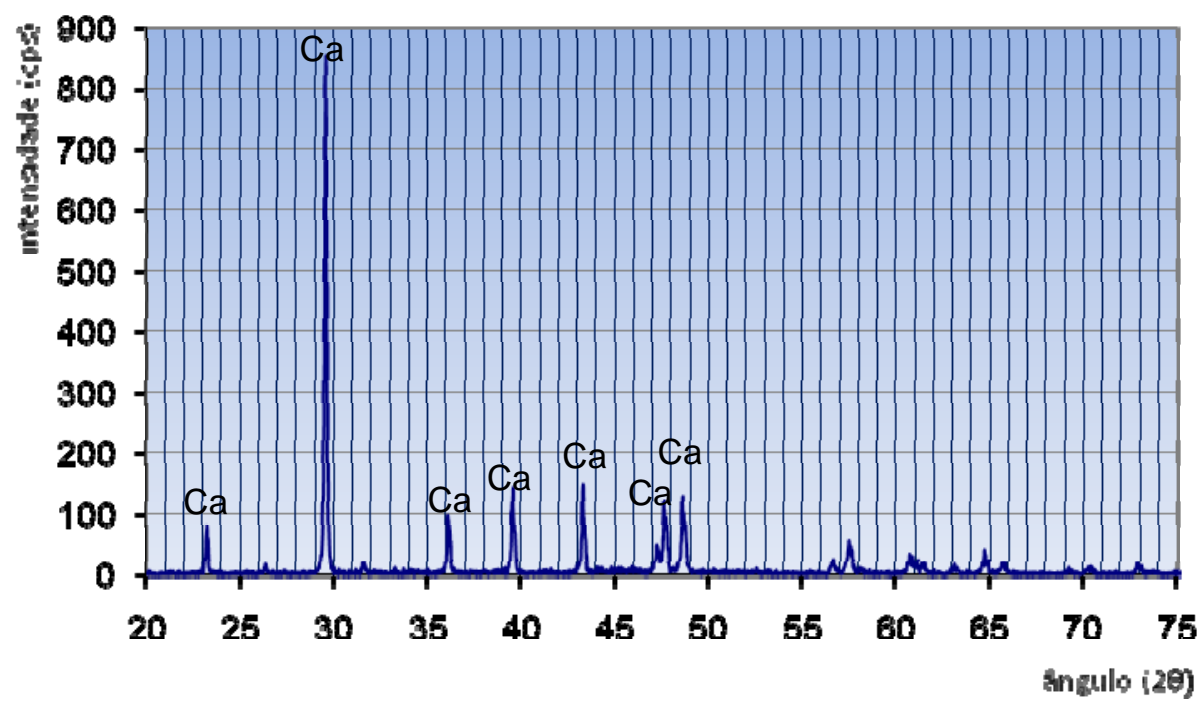

Figura 4.4.2.1 - Curva de difração de raios $X$ do residuo dregs, com indicação da presença de carbonato de cálcio $(\mathrm{Ca})$.

Além disso, ampliando-se o gráfico, observou-se ainda outros picos do carbonato de cálcio, segundo Ficha ICDD 83-0578, nos ângulos $2 \theta$ iguais a $57,410^{\circ} ; 60,682^{\circ}$ e $64,673^{\circ}$ conforme destacado na Figura 4.4.2.2.

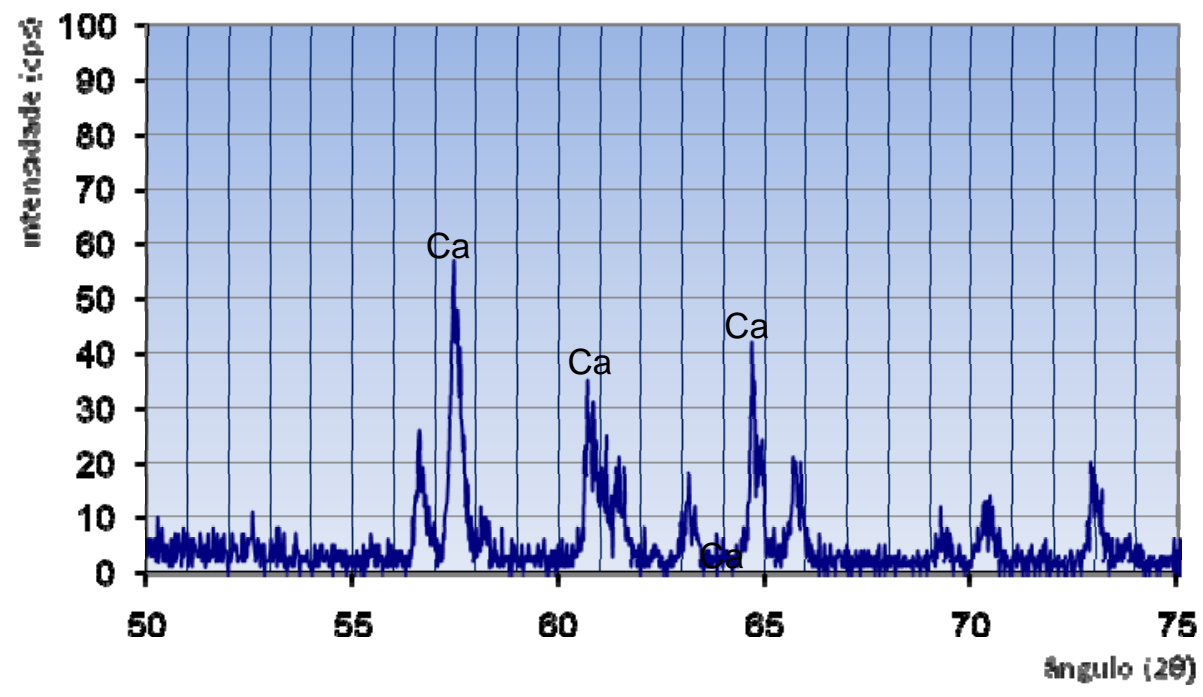

Figura 4.4.2.2 - Curva de difração de raios $X$ ampliadoa do dregs, com indicações de mais picos de carbonato de cálcio $(\mathrm{Ca})$. 


\subsubsection{Grits}

O difratograma do resíduo grits mostrou muita semelhança com aquele do dregs, conforme pode-se ver na Figura 4.4.3.1.

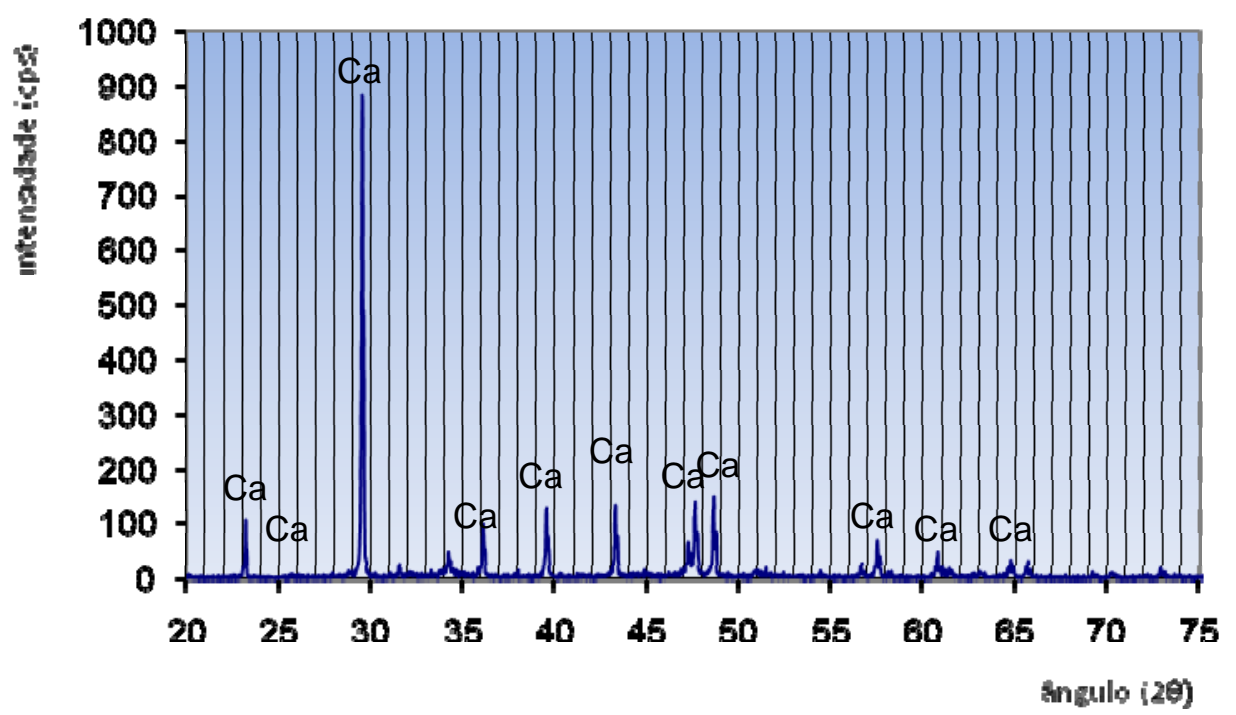

Figura 4.4.3.1 - Curva de difração de raios $X$ do grits, destacando-se a presença da mesma fase (carbonato de cálcio) observada no dregs.

Entretanto a superposição dos difratogramas (Figura 4.4.3.2) mostrou a provavel presença novas fases no grits. Considerando-se a composição química desse residuo, com teores mais elevados de sódio, indicou a possibilidade de presença de carbonato duplo de sódio e cálcio e na presença de carbonato de sódio individualmente, respectivamente fichas 76-1786 e 84-0176 do ICDD. A Figura 4.4.3.3 mostra o destaque para o intervalo de ângulo $2 \theta$ de $10 \mathrm{a} 40^{\circ}$. 


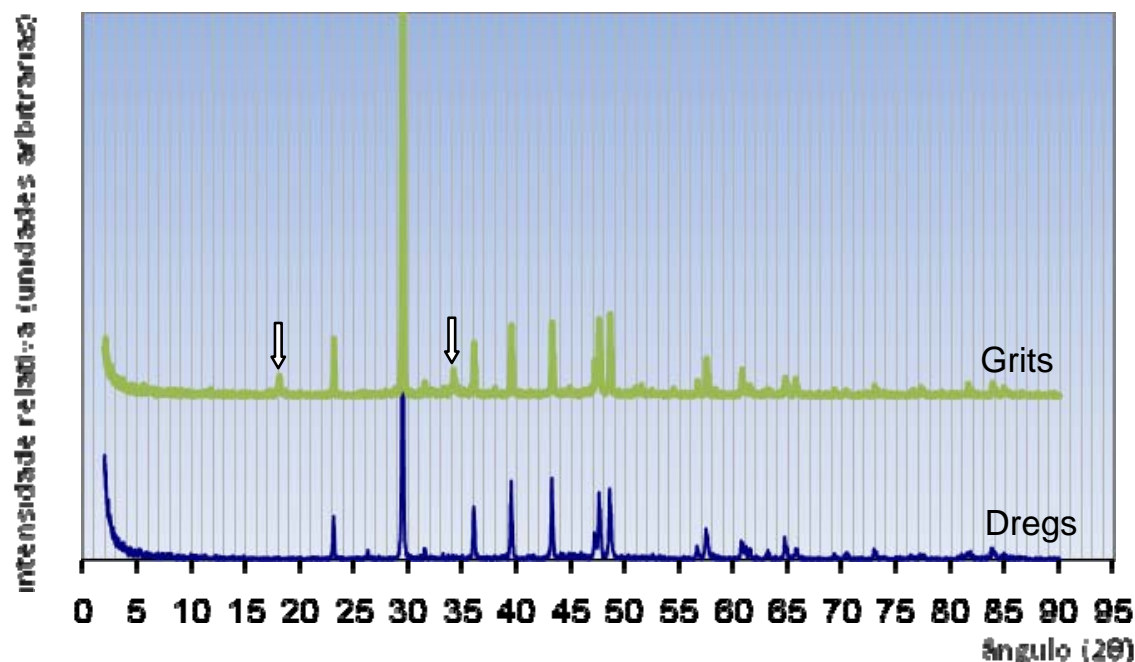

Figura 4.4.3.2 - $\quad$ Curva de difração de raios $X$ do dregs e grits destacanse fases de ocorrência exclusiva no grits em torno dos ângulos $2 \theta$ em torno de $18^{\circ}$ e $34^{\circ}$.

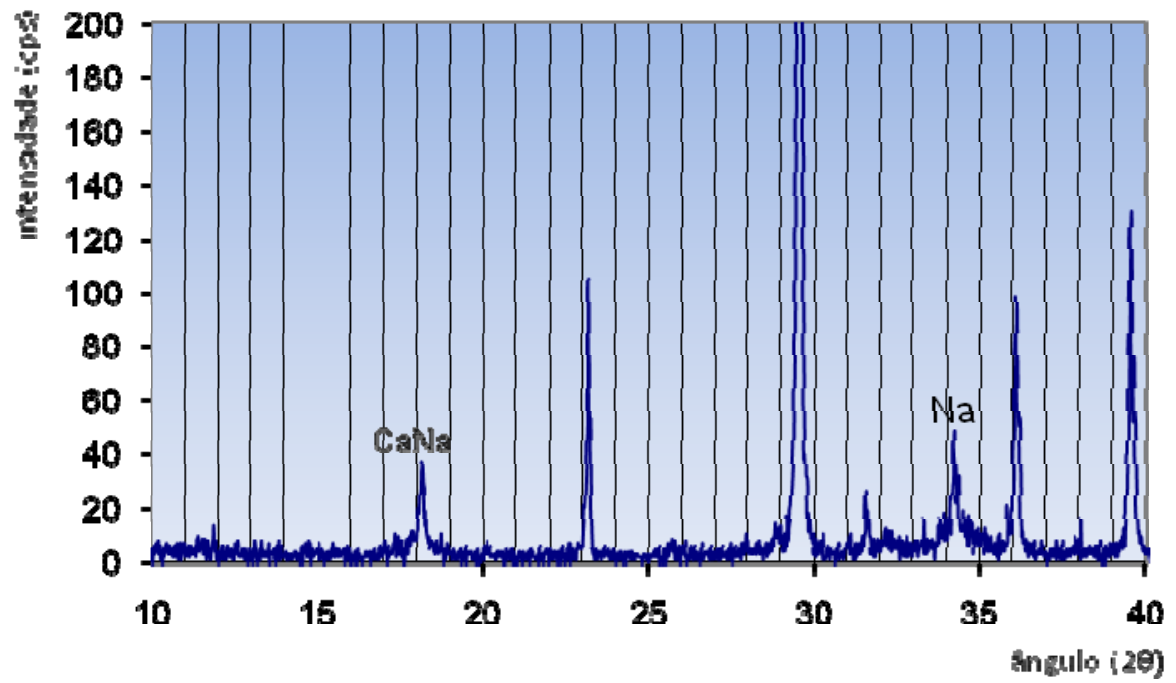

Figura 4.4.3.3 - Curva de difração de raios $X$ ampliado do grits com destaque para as fases identificadas como sendo de carbonato duplo de cálcio e sódio $(\mathrm{CaNa})$ e do carbonato simples de sódio $(\mathrm{Na})$. 


\subsubsection{Mistura da argila com os resíduos}

A mistura a cru contendo $10 \%$ de resíduos (5\% de dregs e $5 \%$ de grits) e $90 \%$ de massa de argila forneceu a curva mostrada na Figura 4.4.4.1. Da análise dos picos vê-se a correlação com a curva para a argila crua pura (Figura 4.4.1.1). Entretanto, destaca-se agora a presença mais proeminente de um pico a um ângulo $2 \theta$ da ordem de $29,410^{\circ}$, indicativa da presença de carbonato de cálcio (Ficha 83-0578 do ICDD), contido nos residuos. Também houve o registro do carbonato duplo de cálcio e sódio a ângulo $2 \theta$ aproximado de $18^{\circ}$.

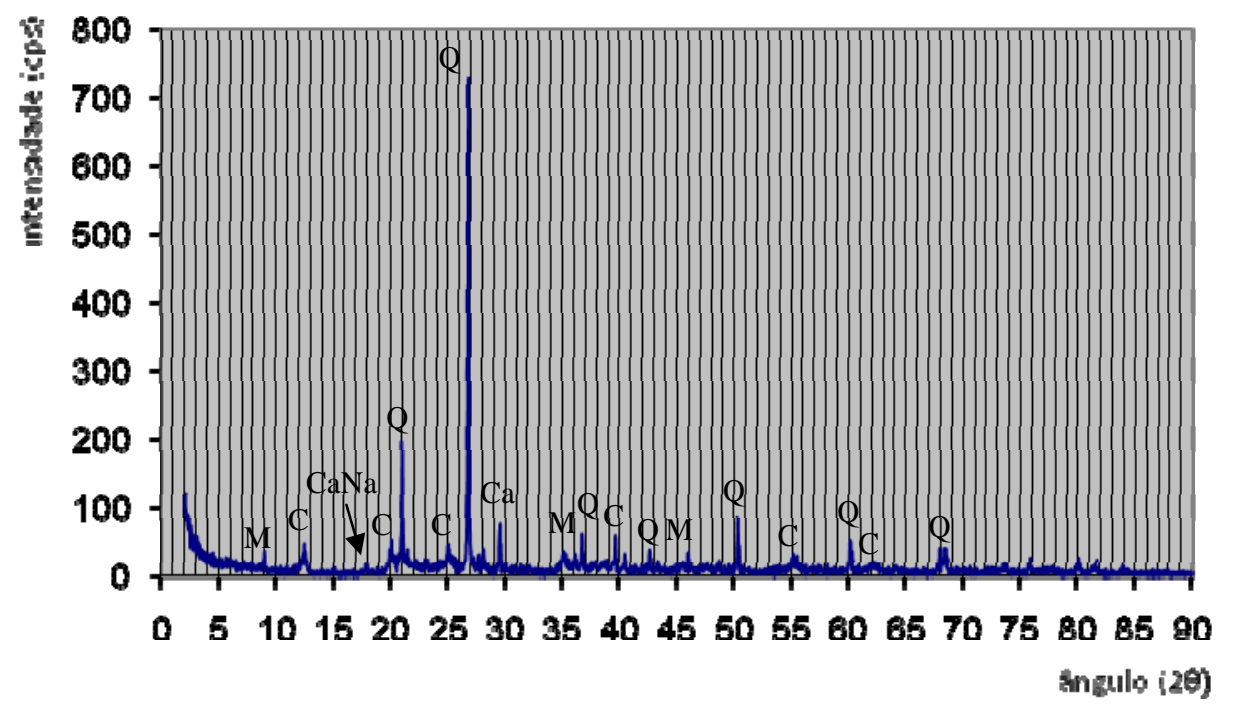

Figura 4.4.4.1 - Curva de difração de raios $X$ da mistura de $10 \%$ de residuos a cru com evidências das estruturas cristalinas do quartzo (Q), da caulinita (C), da muscovita (M) e, adicionalmente, do carbonato de calcio (Ca) e carbonato duplo de calcio e sódio $(\mathrm{CaNa})$. 
A difração de raios X para a mistura de 10\% de resíduos e 90\% de argila queimada a $1000^{\circ} \mathrm{C}$ resultou na curva apresentada na Figura 4.4.4.2. Observa-se o desaparecimento do pico mais caracteristico da muscovita ao ângulo $2 \theta$ igual a $8,853^{\circ}$ e, comparativamente ao difratograma da mistura crua (Figura 4.4.4.1), verifica-se uma menor intensidade nos picos, indicando indiretamente um crescimento no volume de fases amorfas ou vítreas.

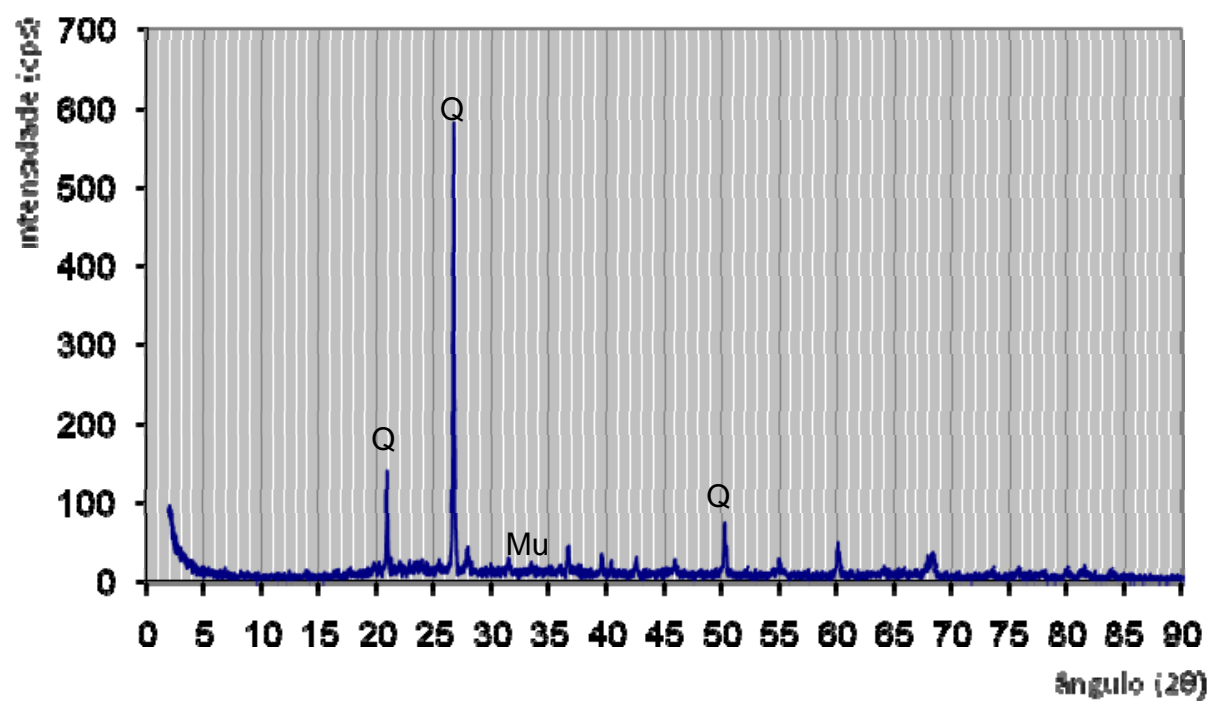

Figura 4.4.4.2 Curva de difração de raios $X$ da mistura de residuos $(10 \%)$ e argila (90\%), queimada a $1.000^{\circ} \mathrm{C}$. Observa-se o desaparecimento do pico da muscovita e um aumento na proporção de fases amorfas.

\subsection{ANÁLISE TÉRMICA}

A interpretação comparativa dos resultados dos ensaios de análise térmica diferencial (ATD), termogravimetria (TG) e também da curva derivada da curva 
termogravimétrica (DTG), é ferramenta importante no entendimento dos resultados dos ensaios cerâmicos, como se discute a seguir.

\subsubsection{Argila}

A análise termogravimetrica da argila, reproduzida na Figura 4.5.1.1, mostrou em torno de $100^{\circ} \mathrm{C}$ um pico endotérmico associado à perda de água livre, com uma perda de massa da ordem de 1,0\%, correspondente ao teor de umidade inicial da amostra. Outro pico endotérmico ocorreu em torno de $530^{\circ} \mathrm{C}$, provavelmente associado à desidroxilação do argilomineral, com redução da massa da ordem de $8,0 \%$. A partir de $1000^{\circ} \mathrm{C}$ observa-se início de reação exotérmica, provavelmente efeito de mudança estrutural da metacaulinita (nucleção de mulita).

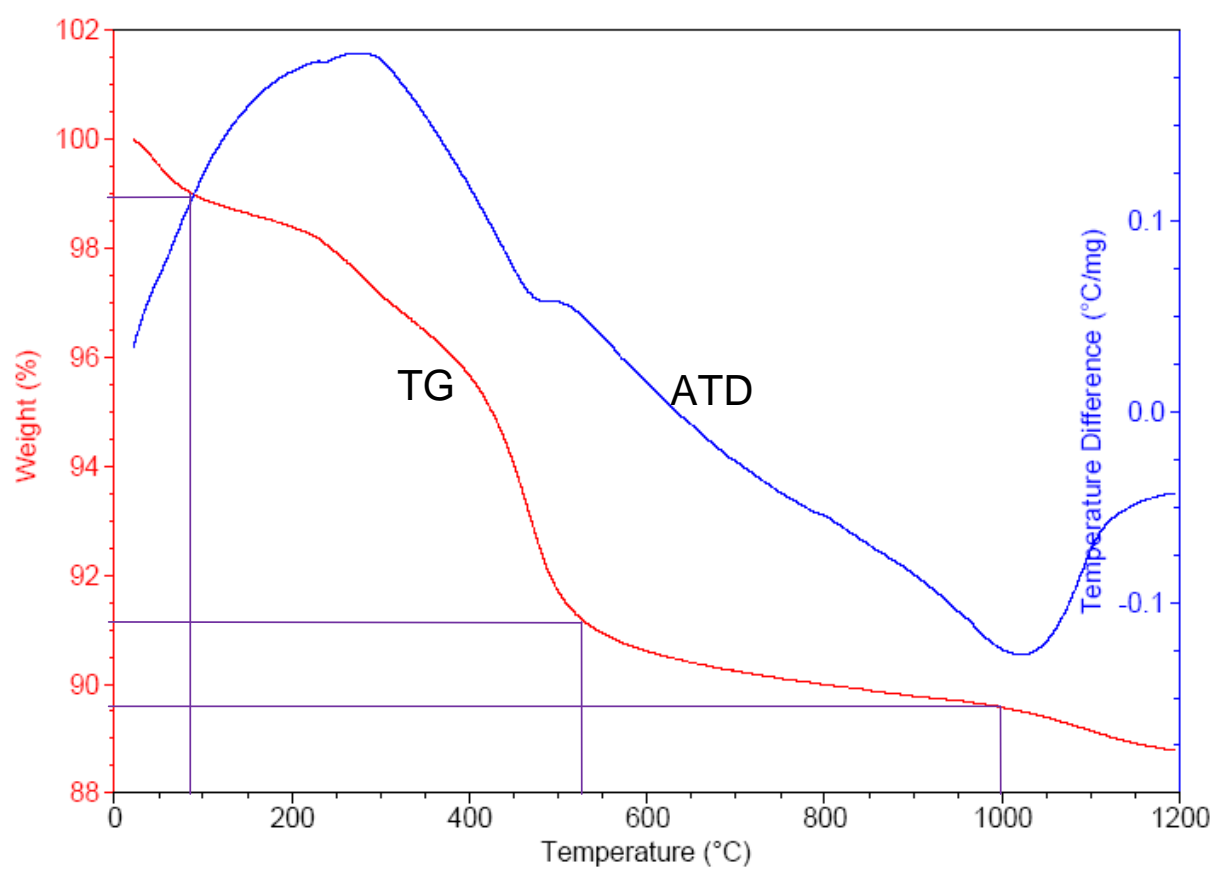

Figura 4.5.1.1 Curva ATD/TG da argila pura, com destaque para a maior perda de massa até cerca de $500^{\circ} \mathrm{C}$. 
A mulita, muito empregada em refratários especiais, é rara na natureza e, para atender um mercado crescente em função das novas aplicações encontradas, os pesquisadores procuram sintetizá-la, principalmente através da mistura de $\mathrm{Al}_{2} \mathrm{O}_{3} \mathrm{e}$ $\mathrm{SiO}_{2}$, ou a partir de minerais que apresentem $\mathrm{Al}_{2} \mathrm{O}_{3}$ e $\mathrm{SiO}_{2}$ em suas composições, conforme destaca BRASILEIRO et al. (2006).

A perda total de massa da argila até a temperatura maxima utilizada nos trabalhos para a produção de peças cerâmicas de $1000^{\circ} \mathrm{C}$ foi da ordem de $10,5 \%$.

\subsubsection{Dregs}

O resultado da análise termogravimétrica do dregs mostrou uma perda siginificativa de massa, da ordem de $40 \%$, culminando na temperatura da ordem de $725^{\circ} \mathrm{C}$, condizente com a faixa de temperatura para a descarbonatação, isto é, decomposição do material com liberação de $\mathrm{CO}_{2}$ (Figura 4.5.2.1). 


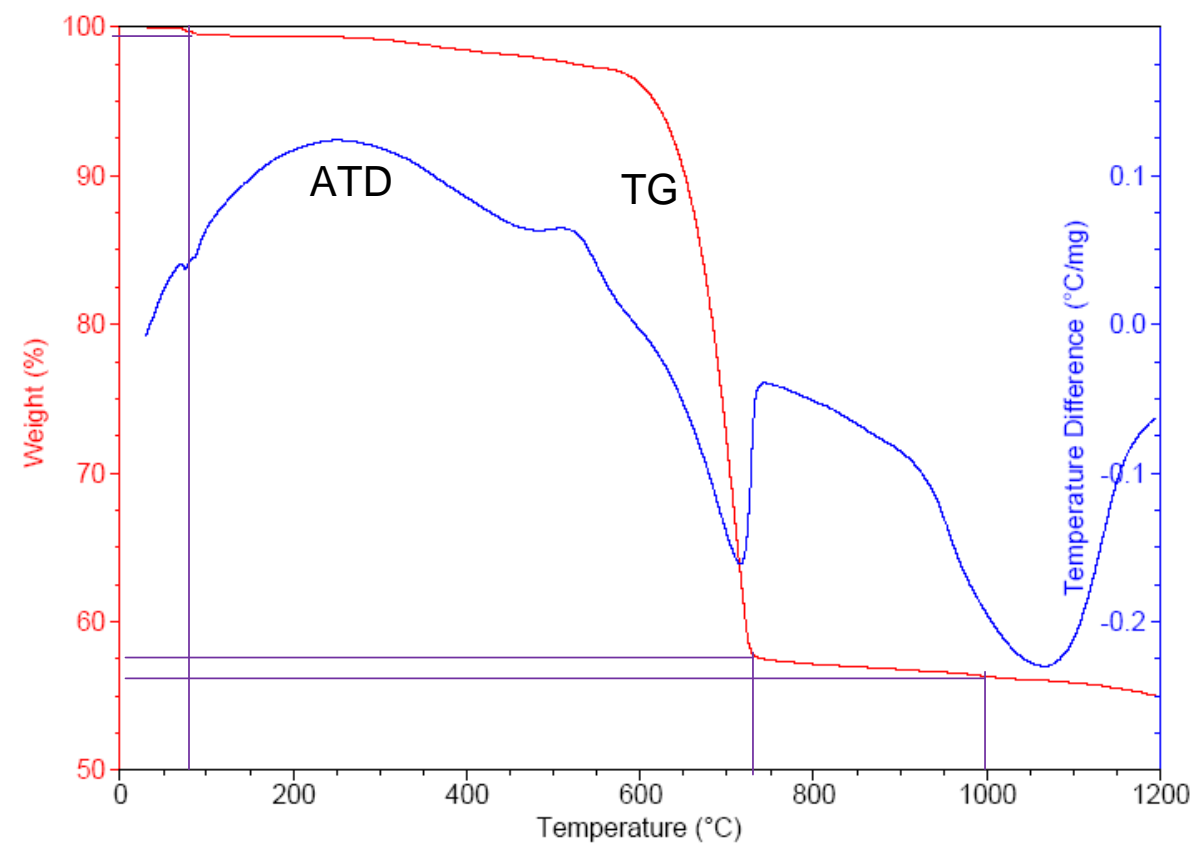

Figura 4.5.2.1 Curvas ATD/TG do dregs destacando-se principalmente evento de descarbonatação ocorrido entre $600^{\circ} \mathrm{C}$ até cerca de $725^{\circ} \mathrm{C}$, quando se deu uma perda de massa superior a $40 \%$.

A perda de massa total sofrida pela amostra de dregs, considerada até a temperatura máxima dos ensaios cerâmicos, que foi de $1.000^{\circ} \mathrm{C}$, correspondeu a aproximadamente $44 \%$, muito proxima aos $42,9 \%$ registrado em termos de perda ao fogo na análise química do material (Tabela 4.2.1). O resultado obtido é semelhante ao apresentado por ALMEIDA (2007) estudou resíduo semelhante, cujo resultado é reproduzido na Figura 4.5.2.2. 


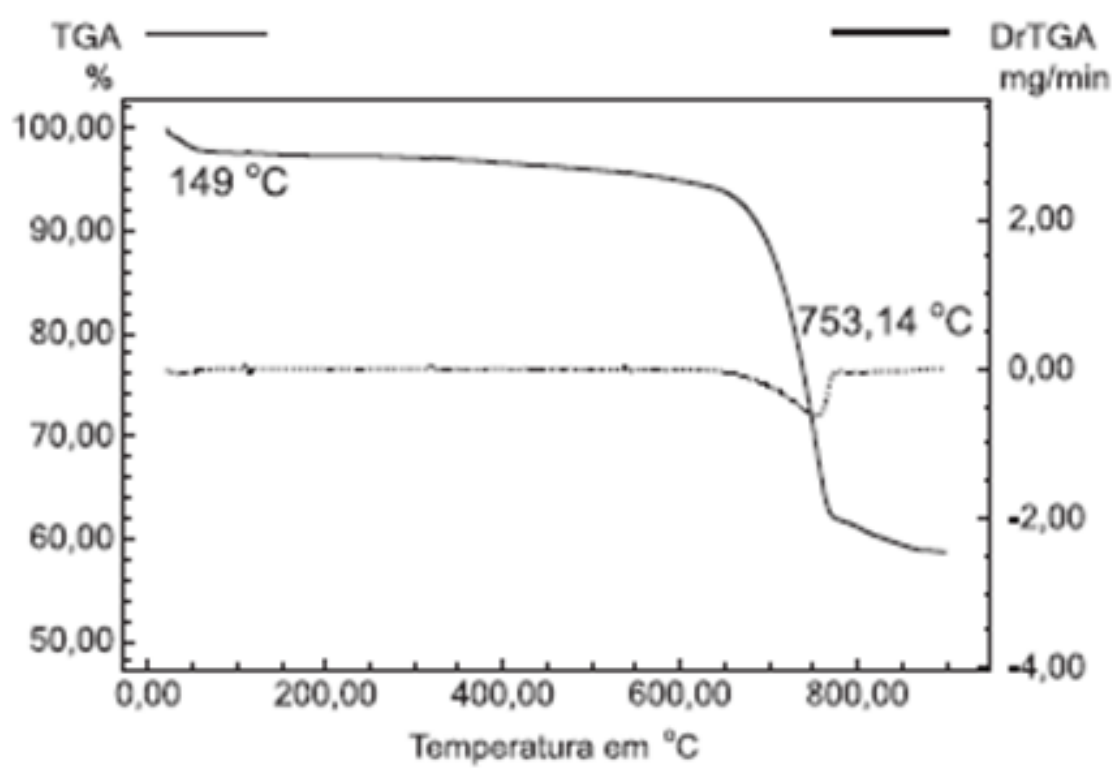

Figura 4.5.2.2 Resultado de análise térmica de dregs obtido por ALMEIDA (2007).

\subsubsection{Grits}

A curva de ATD/TG do grits, mostrada na Figura 4.5.3.1, apresentou o mesmo evento endotérmico com elevada perda de massa em torno de $715^{\circ} \mathrm{C}$. Entretanto, se destacam mais nesta curva, relativamente a do dregs, os eventos iniciais de perda de água, ou desidratação, culminando a $175^{\circ} \mathrm{C}$, assim como uma reação endotérmica intermedária por volta dos $400^{\circ} \mathrm{C}$, que pode representar a eliminação de matéria orgânica ainda presente no resíduo. 


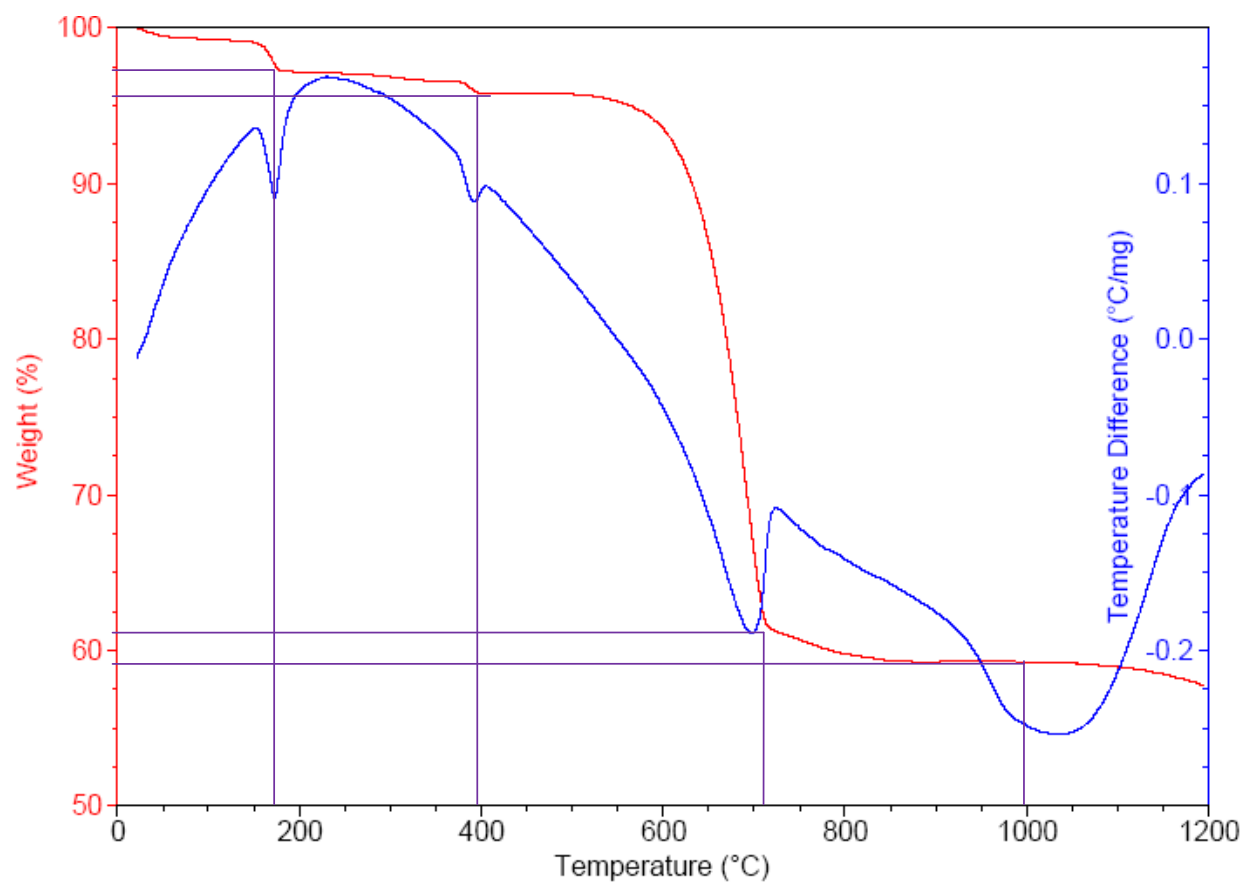

Figura 4.5.3.1 Curvas ATD/TG do grits, mostrando maior reação endotermica se dando em torno de $700^{\circ} \mathrm{C}$ por perda de $\mathrm{CO}_{2}$. A perda de agua e provavel conteudo de materia organica foram mais marcantes que com o dregs.

A perda de massa registrada pelo grits até a temperatura de $1000^{\circ} \mathrm{C}$ foi da ordem de $40,5 \%$, abaixo da perda de massa registrada pelo dregs. Isso se deu, muito provavelmente, pelo menor conteúdo de cálcio encontrado no grits relativamente ao dregs, na forma de carbonatos.

\subsubsection{Mistura da argila com os resíduos}

Utilizou-se da análise térmica diferencial para avaliar-se não somente a composição contendo $10 \%$ de residuos (melhor comportamento cerâmico), mas também a composição contendo $20 \%$ de resíduos, que não apresentou as propriedades adequadas para a produção de cerâmica, como forma de investigar as prováveis causas. 
4.5.4.1. Argila com $10 \%$ de resíduos

Com $10 \%$ de residuos as curvas ATD/TG se comportaram como mostra a Figura 4.5.4.1.1. Interessante observar nesse gráfico a reprodução dos efeitos registrados isoladamente na análise térmica da argila e dos residuos, agora simultaneamente. A perda de água de umidade deu-se entre 50 e $100^{\circ}$ e a perda de hidroxila na argila, reproduziu-se na mesma faixa de temperatura, próxima a $500^{\circ} \mathrm{C}$, mas com menos perda de massa. A descarbonatação deu-se na mistura por volta de $660^{\circ} \mathrm{C}$. No total, a perda de massa foi de $10,2 \%$, contra $10,5 \%$ da massa contendo apenas argila.

Os três eventos mencionados aparecem melhor definidos quando se analisa o grafico com o acrescimo da curva de derivada da perda de massa (DTG), Figura

\subsubsection{2.}

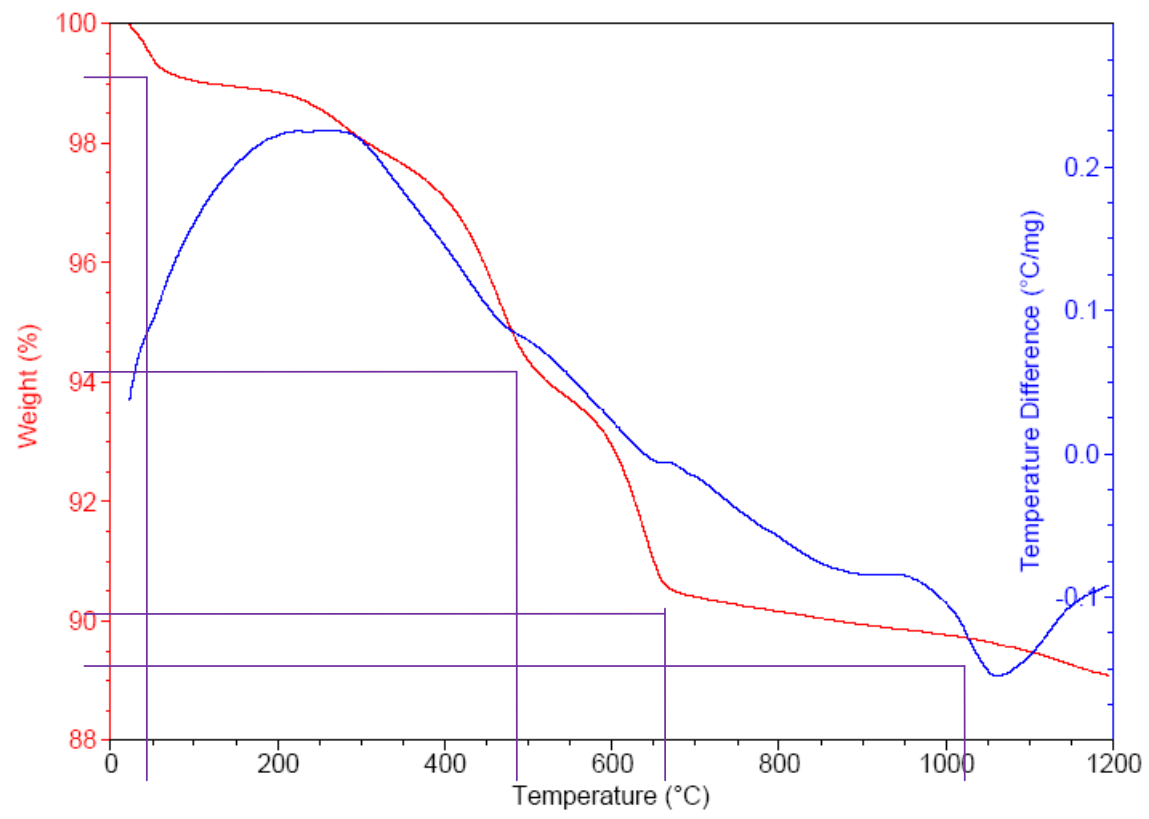

Figura 4.5.4.1.1. Curvas TG/ATD da mistura com $10 \%$ de resíduos mostrando os eventos, de perda de água próximo a $100^{\circ} \mathrm{C}$, a perda de hidroxilas em torno de $500^{\circ} \mathrm{C}$, e de carbonatos por volta de $670^{\circ} \mathrm{C}$. 


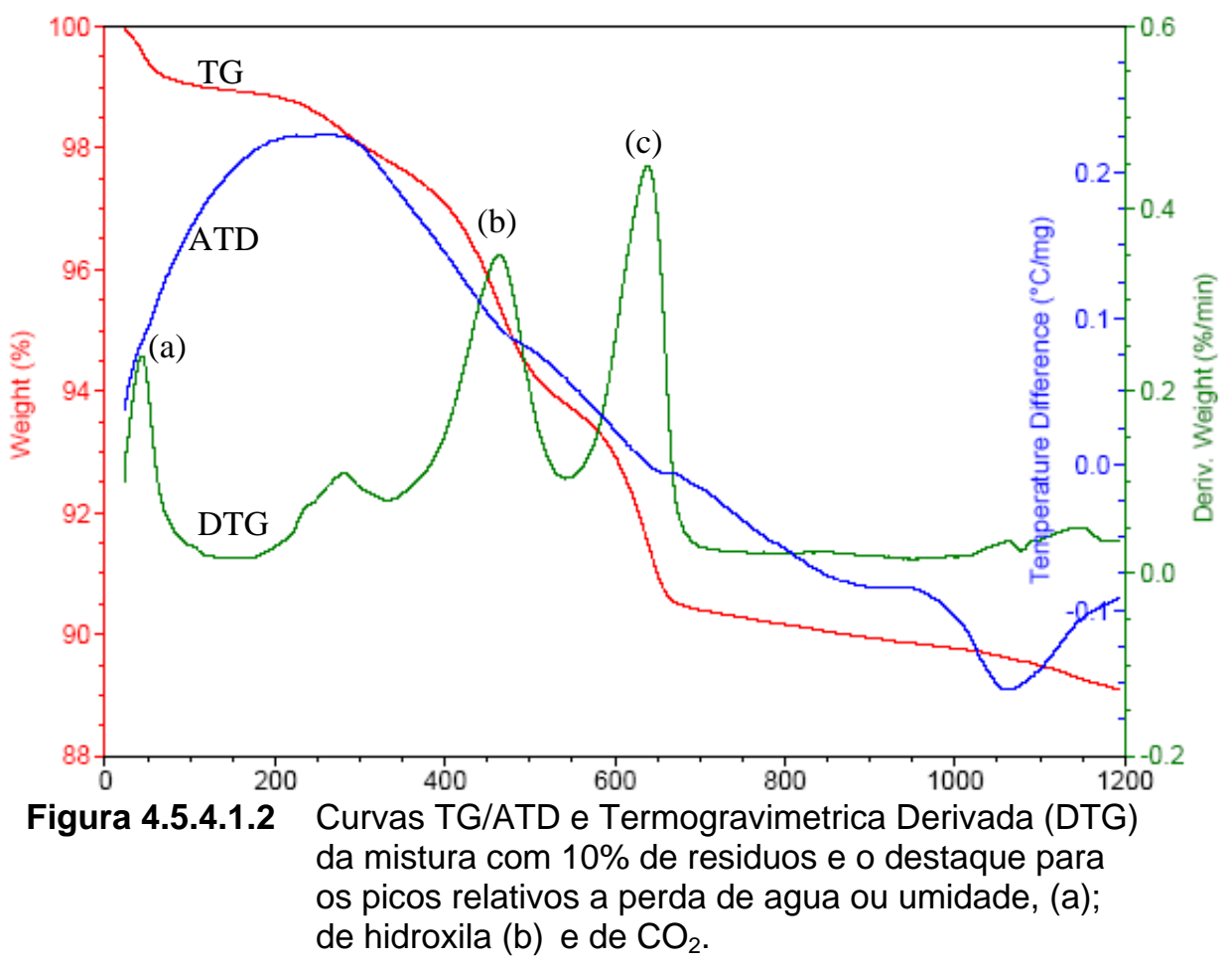

\subsubsection{Argila com $20 \%$ de residuos}

Com $20 \%$ de residuos verificou-se nas curvas resultantes, apresentadas na Figura 4.5.4.2.1, as ocorrências dos eventos endoteérmicos de perda de agua livre e estrutural, em temperaturas semelhantes para a formulação contendo $10 \%$ de resíduo, dando-se a descarbonatação desta vez a temperturas mais próximas de $700^{\circ} \mathrm{C}$. Entretanto, a perda de massa dessa formulação com a temperatura foi maior, especialmente no ultimo evento, onde a perda do gas carbônico foi acompanhada de uma redução de massa aproximada de $9 \%$, contra $4 \%$ para o mesmo evento com $10 \%$ de residuos. 


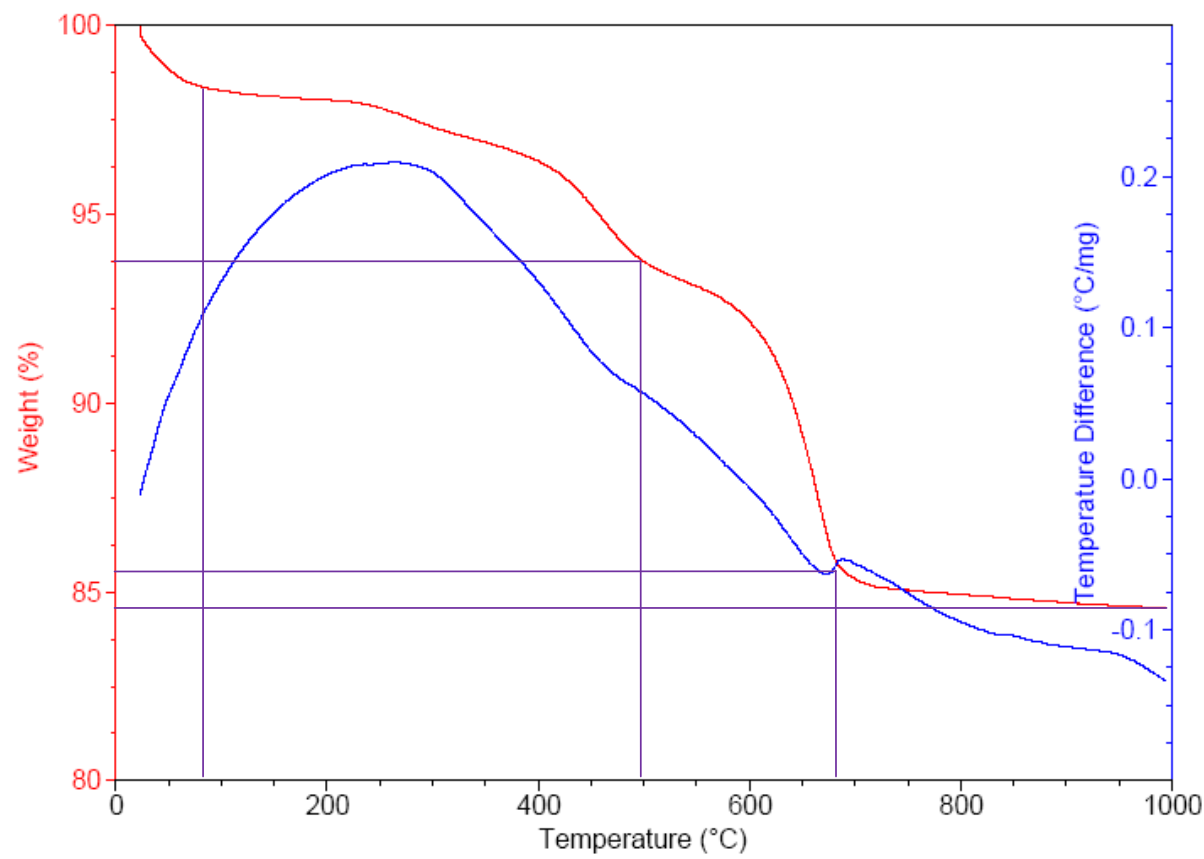

Figura 4.5.4.2.1 Curvas ATD/TG da formulação contendo 20\% de resíduos, mostrando os três (3) eventos registrados anteriormente com menor percentual de resíduos, porem agora com uma maior perda de massa, especialmente durante o evento de descar bonização ocorrido próximo a $700^{\circ} \mathrm{C}$.

No total, a perda de massa registrada na análise térmica diferencial da amostra contendo $20 \%$ de residuos somou $15,5 \%$, contra $10,2 \%$ para a composição com $10 \%$ de residuos. A perda maior de massa com essa composição teve como consequencia o aumento da porosidade, resultando no aumento da absorção de água e da retração linear, trazendo associadas uma menor massa especifica aparente e menor resistencia mecânica das peças produzidas, conforme pode ser verificado na Tabela 4.3.1 apresentada anteriormente. 


\subsection{MICROSCOPIA ELETRÔNICA DE VARREDURA}

Atravás da microscopia eletronica de varredura (MEV) foi possível observar-se a morfologia das particulas constituintes dos materiais estudados individualmente e as microestruturas dos materiais obtidos após a queima.

A argila pura, verde ou crua, e a queimada a $1.000^{\circ} \mathrm{C}$ aparecem justapostas na Figura 4.6.1. Destaca-se da observação das imagens a granulometria muito fina do material, com grãos constituintes de diametros inferiores a $5 \mu \mathrm{m}(0,005 \mathrm{~mm})$, e a forma lamelar de seus constituintes individuais. Entretanto não se observam cristais euédricos, ou bem formadas, entre esses constituintes, pelo efeito de retrabalhamento dos depositos de argila nos ciclos de transporte e deposicao natural, pois não se trata de uma jazida sedimentar sob ação do meio fluvial, onde os fenomenos de erosão, transporte e deposição dos minerais findaram por alterar as formas originais dos constituintes remanescentes.

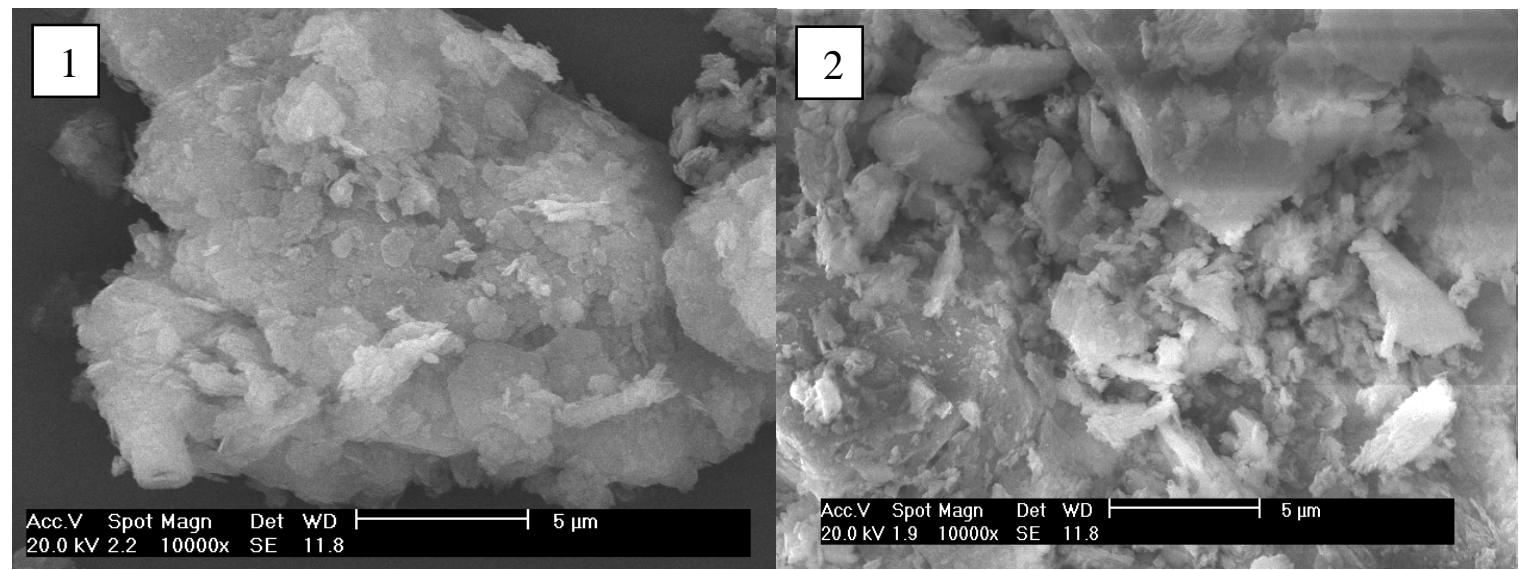

Figura 4.6.1 Imagens da argila crua (1) e queimada a $1.000^{\circ} \mathrm{C}$ (2) onde é destaque a granulometria fina e a forma lamelar dos materials constituintes, e um certo grau de sinterização da massa queimada. 
Resultados de microsondagem sobre a amostra de argila, obtidos através de espectros EDS (energy dispersive spectroscopy), equipamento acoplado ao MEV, indicaram a presença predominante na massa de argila de alumínio, silício, potássio, magnésio e ferro (Figura 4.6.2).

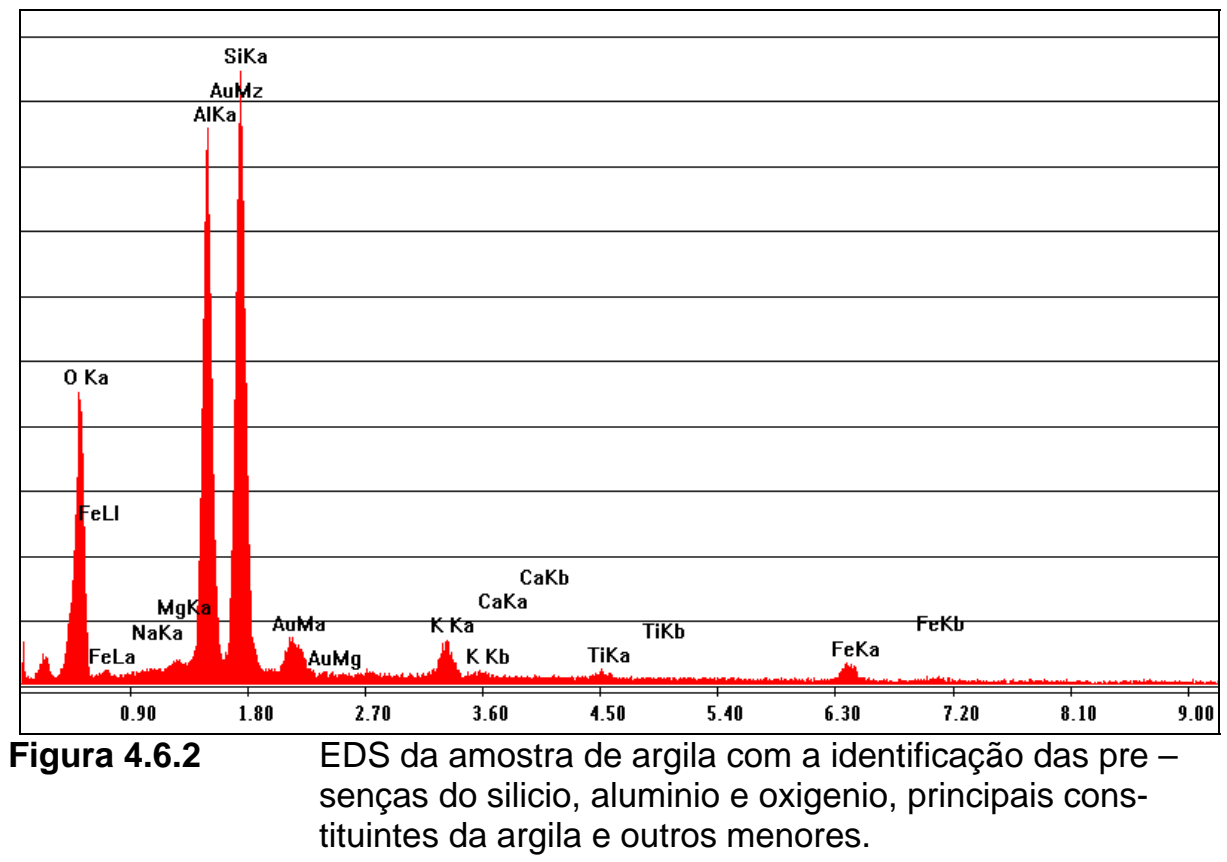

Pela análise quimica desse material, apresentada na Tabela 4.2.1, verifica-se que sílica e alumina formam mais de $80 \%$ de sua constituição. Associando-se a isso as difrações de raios $X$ pode-se afirmar que tratam-se de argilas predominantemente cauliníticas. Esses minerais são abundantes na região, onde se tem uma das maiores jazidas de caulim do mundo. Os elementos ferro, potassio, magnesio, identificados tanto na análise quimica quanto na microsondagem, podem estar relacionadas à presença dos mesmos entre as folhas de hidroxidos de aluminio e silicatos das caulinitas ou fazerem parte da composicao estrutural dos filossilicatos como a muscovita cujas presença foi indicda na análise de difração de raios $\mathrm{X}$. 
A mistura dos residuos na proporção de $10 \%$ na massa de argilominerais pode ser vista na Figura 4.6.3, com destaque para alguns pontos com aglomerações distintas do resto, presentes na matriz.

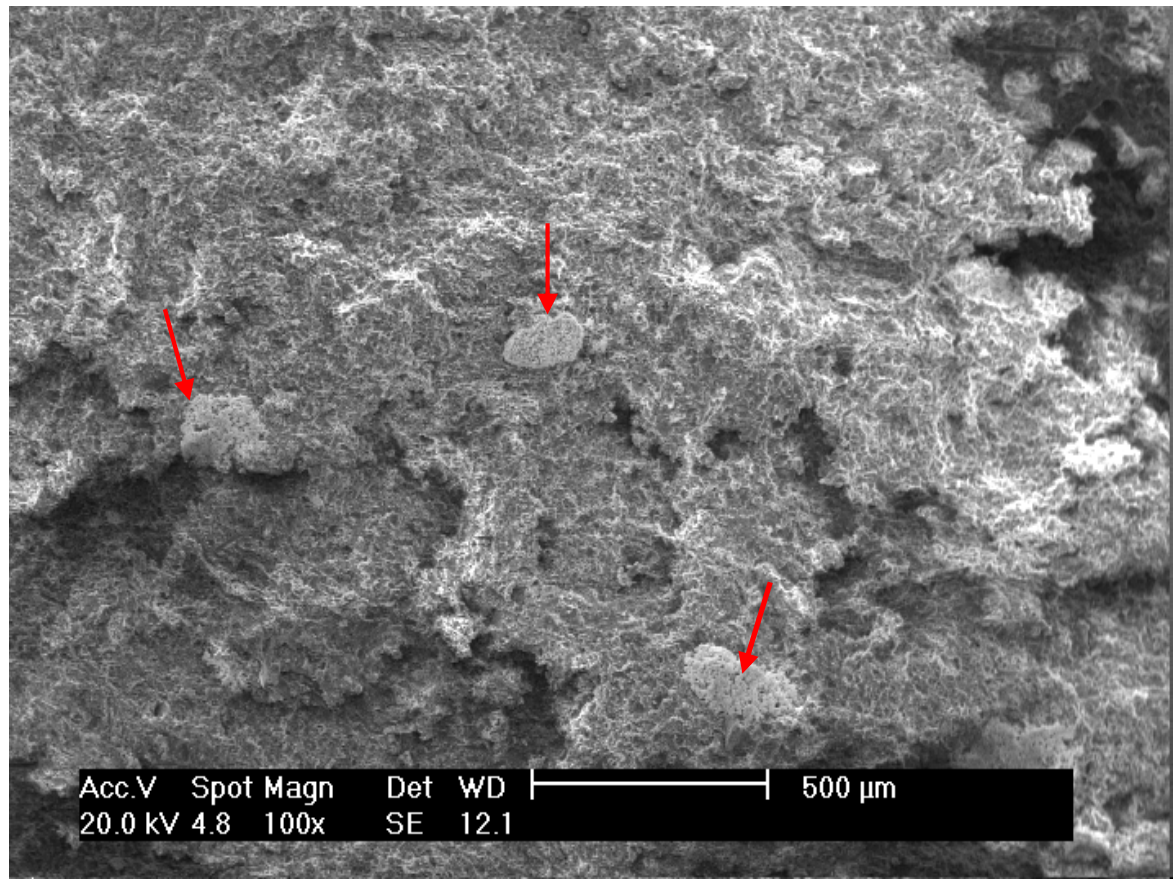

Figura 4.6.3 Imagem da mistura de argila com 10\% de residuos ampliada 100 vezes com setas destacando alguns grumos.

Na Figura 4.6.4 apresenta-se destacado um dos grumos visualizados na imagem anterior. A microsondagem com EDS sobre essa pequena área resultou no gráfico mostrado na Figura 4.6.5 conclusivo por uma composição desse material à base de cálcio, levando-se à conclusão de ser a mesma parcela do residuo excedente na combinação ou resultado de uma mistura inicial não muito eficiente. 


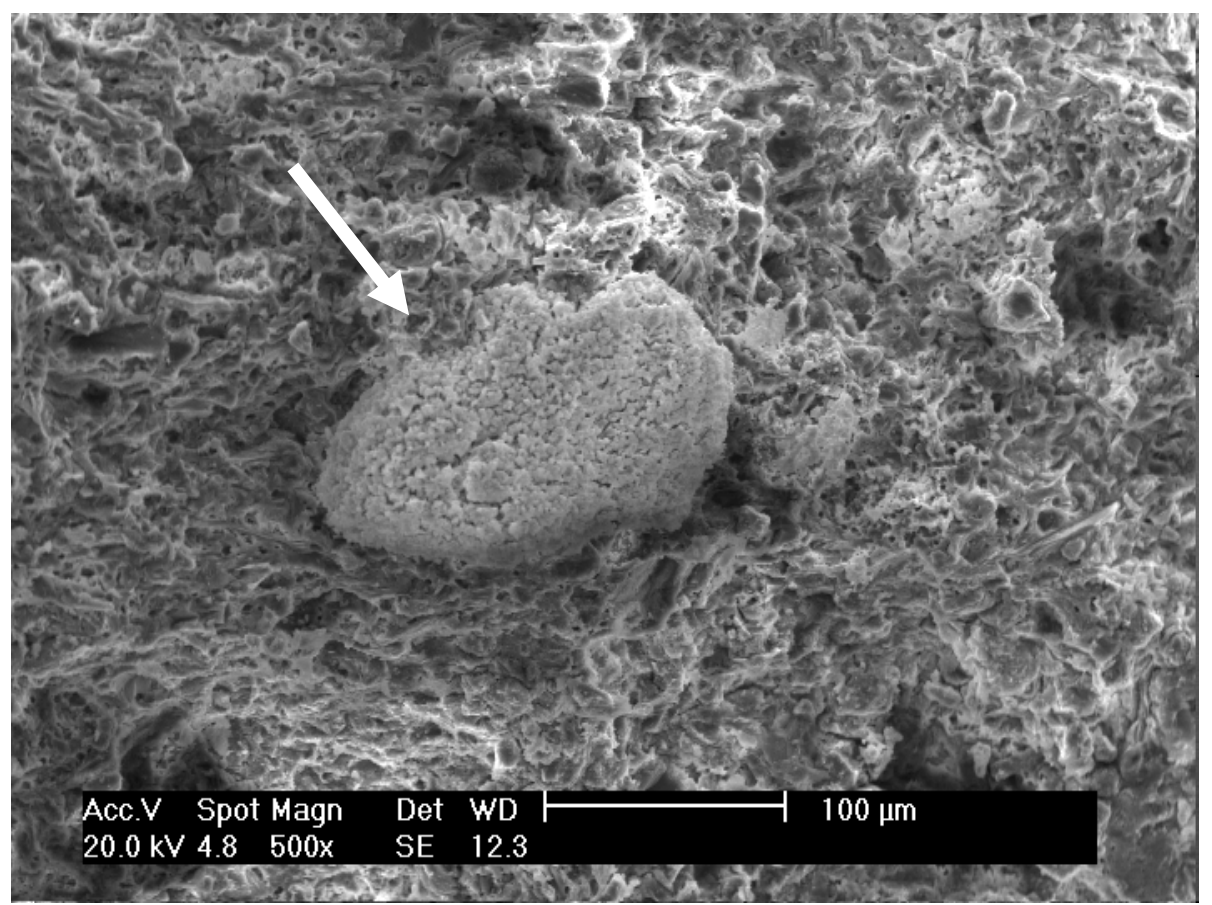

Figura 4.6.4 Detalhe do residuo, como um aglomerado, isolado na massa formada pelos argilominerais.

A Figura 4.6.6 mostra juntas a imagem da argila queimada a $1000^{\circ} \mathrm{C}$, à esquerda e, à direita, da argila $+10 \%$ dos residuos queimada na mesma temperatura. Ambas imagens ampliadas em 15.000 vezes mostram que a mistura com o residuo favorece uma maior sinterização da massa. Isso se deu provavelmente pela presença dos elementos fundentes do residuo que favoreceram o evento. Essa sinterização mais expressiva da mistura é a responsavel pela maior resistência mecânica apresentada pelo material, alem da redução da absorção de agua e aumento da densidade, pela diminuição da porosidade aparente, observados nos resultados dos ensaios cerâmicos. 


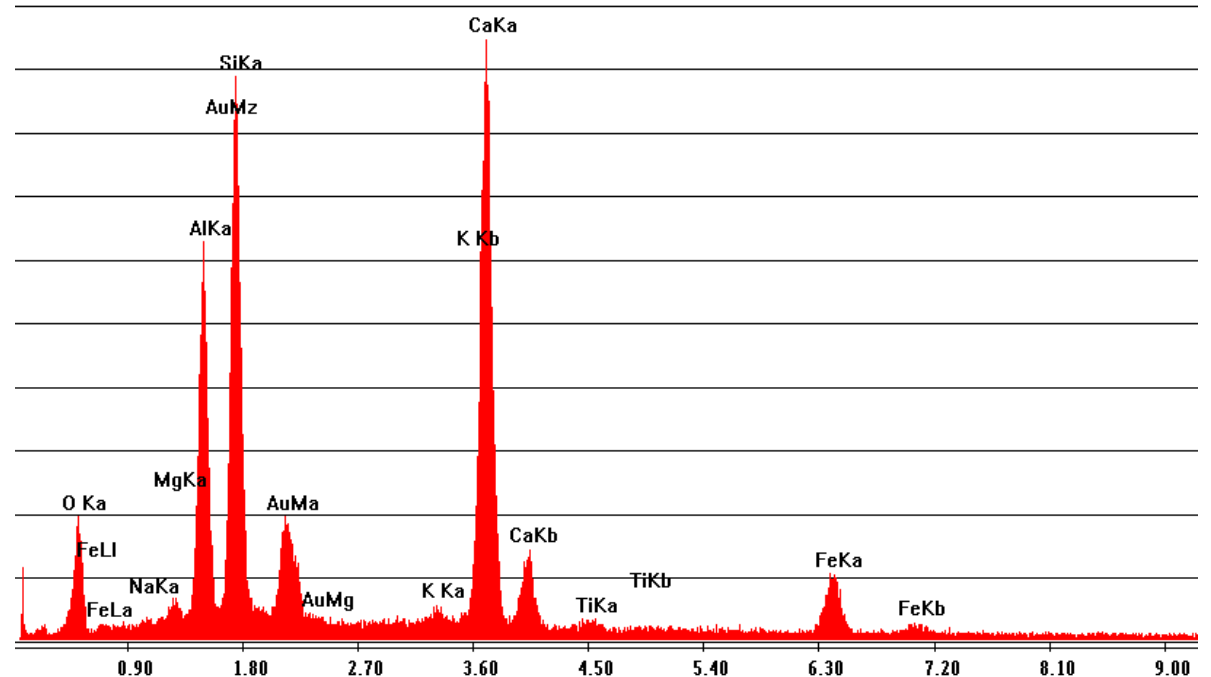

Figura 4.6.5. $\quad$ EDS sobre o aglomerado do residuo destacado com seta na imagem anterior.

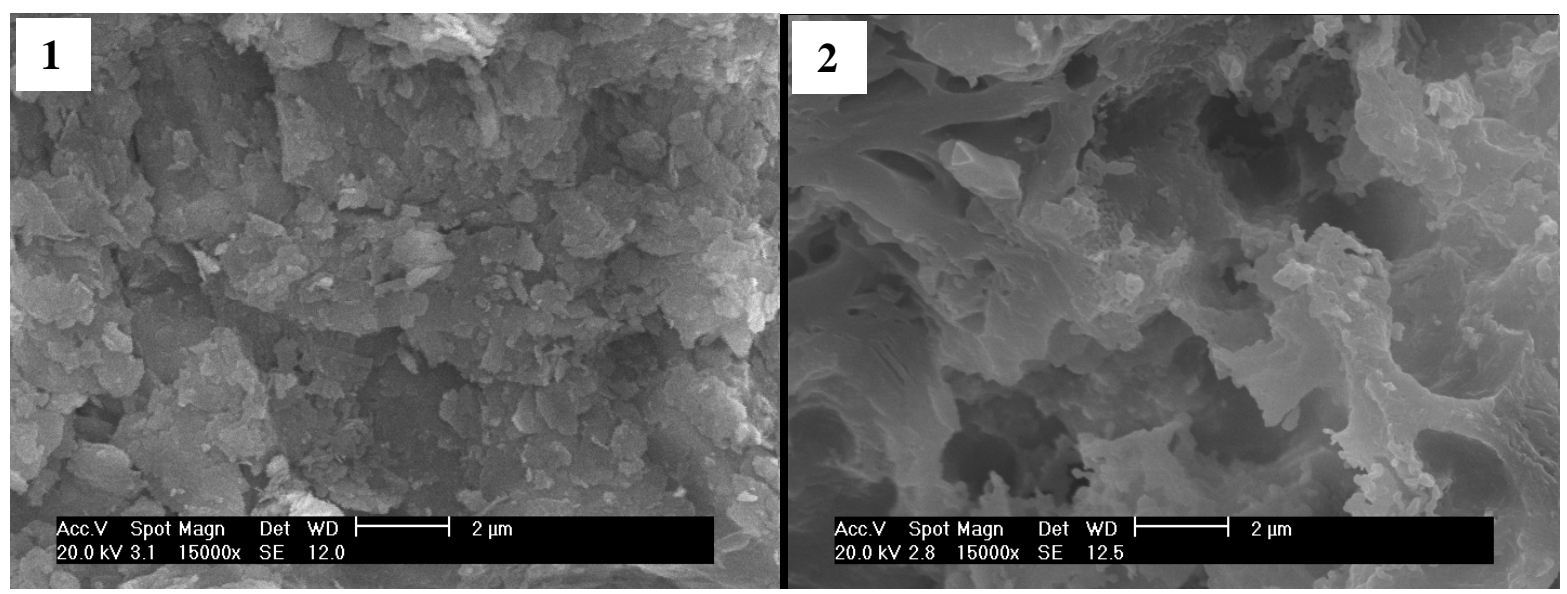

Figura 4.6.6. Imagens de microscopia eletronica de varredura vendo-se a esquerda (1) resultado do corpo de prova constituido de $100 \%$ de argila e a direita (2) corpo de prova contendo $10 \%$ de residuos e $90 \%$ de argila, ambos queimados a $1.000^{\circ} \mathrm{C}$. Na imagem 2 é nitida a evidencia de ter havido uma sinterizacao maior dos constituintes, onde o material mostra uma estrutura vitrea predominante. 


\subsection{ENSAIO DE SOLUBILIZAÇÃO}

De acordo com a norma ABNT - NBR 10.006 (2004) foram realizados ensaios de solubilização para a mistura em igual partes do dregs e grits, considerada simplesmente como "resíduo", e para o material ceramico produzido com ambos, na concentração de $10 \%$ do peso em massa, e queimado a $1.000^{\circ} \mathrm{C}$. Os ensaios foram feitos na empresa Puriquima Ltda. e os resultados constam da Tabela 4.7.1.

Tabela 4.7.1 - Resultados de analises quimicas sobre os solubilizados produzidos sobre amostras dos residuos e de peça cerâmica contendo $10 \%$ dos mesmos, queimada a $1.000^{\circ} \mathrm{C}$. Em vermelho, valores acima do maximo permitido para que o material seja considerado como inerte pela NBR 10.004/04.

\begin{tabular}{|l|r|r|r|}
\cline { 2 - 4 } \multicolumn{1}{c|}{} & $\begin{array}{r}\text { ANEXO G } \\
\text { NBR 10004 }\end{array}$ & $\begin{array}{r}\text { RESULTADOS ENSAIOS } \\
\text { (mg/l) }\end{array}$ \\
\hline Parametro & maximo (mg/l) & residuos & ceramica \\
\hline Aluminio & 0,20 & $<0,1$ & $<0,1$ \\
Arsenio & 0,01 & $<0,005$ & $<0,005$ \\
Bario & 0,70 & 0,20 & 0,20 \\
Cadmio & 0,01 & $<0,001$ & $<0,001$ \\
Chumbo & 0,01 & $<0,001$ & $<0,001$ \\
Cloreto & 250,00 & 865,00 & 10,00 \\
Cobre & 2,00 & 0,04 & $<0,02$ \\
Cromo total & 0,05 & $<0,02$ & $<0,02$ \\
Ferro & 0,30 & 0,18 & $<0,02$ \\
Manganes & 0,10 & 0,06 & $<0,02$ \\
Mercurio & 0,00 & $<0,001$ & $<0,001$ \\
Prata & 0,05 & $<0,02$ & $<0,02$ \\
Selenio & 0,01 & $<0,005$ & $<0,005$ \\
Sodio & 200,00 & $4.830,00$ & 71,00 \\
Sulfato (expresso em SO4) & 250,00 & $17.991,00$ & 50,00 \\
Zinco & 5,00 & 0,08 & $<0,02$ \\
\hline
\end{tabular}


Através desse ensaio verificou-se que os residuos sólidos estudados, oriundos de uma industria de celulose, apresentam teores de elementos e compostos quimicos na solução lixiviada, acima dos padrões para serem considerados inertes. Entretanto, verificou-se que a introdução dos mesmos numa matriz cerâmica, composição empregada na produção de peças cerâmicas, após queima a $1000^{\circ} \mathrm{C}$, inertiza os referidos resíduos, não permitindo que eles sejam lixiviados pela solução de ataque em níveis acima dos limites impostos pela norma. A cerâmica assim obtida é classificada como material inerte, segundo a nomeclatura prescrita pela norma NBR 10.004.

\subsection{TESTE PRELIMINAR DE PRODUÇÃO}

O teste de produção foi feito com a mistura de $10 \%$ dos residuos na massa empregada por uma olaria, produtor local de blocos cerâmicos para a construção civil. Na Figura 4.8.1 mostra-se, na imagem maior, uma das peças ainda crua sendo marcada para identificação da mesma após a queima. No destaque, a peça já queimada, que se apresentou, visualmente, idêntica às produzidas apenas com argila, inclusive na cor.

Esse resultado reforça, de maneira prática, a viabilidade do uso de dregs e grits, na proporção indicada preliminarmente nos testes laboratoriais, para a produção comercial de blocos cerâmicos de construção, já dentro dos parâmetros de produção empregados pela indústria rudimentar presente na região. 


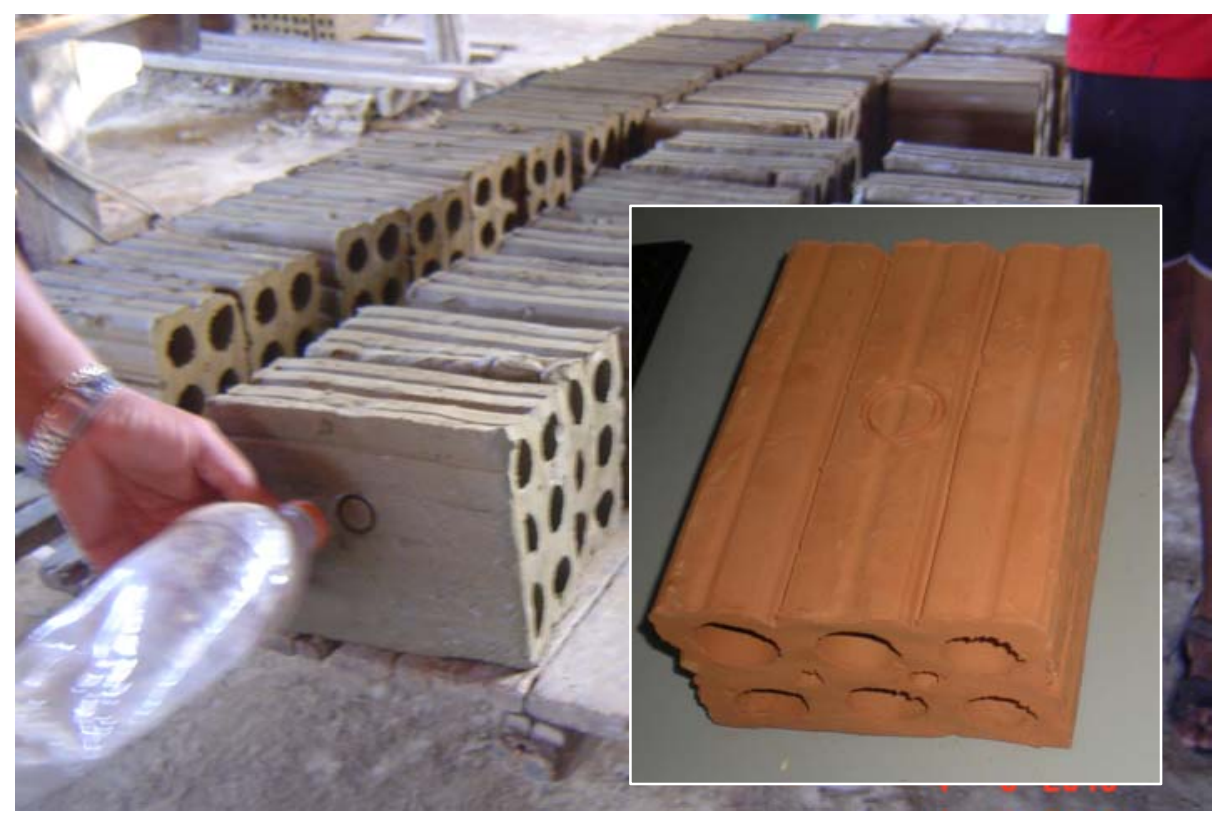

Figura 4.8.1 Produção da peça a cru, na imagem maior, mostrando a marca feita para a identificação da amostra e, no detaIhe, a mesma peça, após queima. 


\section{CONCLUSÕES}

As análises dos resultados obtidos neste estudo permitem concluir que é possível a incorporação de resíduos do tipo dregs e grits provenientes da fabricação de celulose, em argilas comuns utilizadas em indústria cerâmicas para a fabricação de produtos de cerâmica vermelha ou estrutural, tais como tijolos, blocos e telhas cerâmicas.

Dentre os teores de adição investigados, $10 \%$ de adição de resíduos foi o teor que se mostrou mais eficiente em promover melhoria nas propriedades quando comparadas com as propriedades obtidas para o produto fabricado apenas com argila.

A adição de $10 \%$ de resíduos promoveu a diminuição da porosidade, o aumento da massa específica aparente, a formação de maior quantidade de fase vítrea no material queimado e, conseqüente, a diminuição da absorção de água e aumento da resistência mecânica dos corpos de prova cerâmica estudados. A cor pós-queima dos corpos de prova com esse percentual de resíduo praticamente não se alterou.

Assim, por conterem elevados teores de elementos fundentes (particularmente cálcio) e teores pequenos de outros metais (inclusive ferro), os resíduos estudados apresentam potencial para incorporação a outros tipos de massas cerâmicas, podendo inclusive resultar em melhorias na qualidade dos produtos e principalmente numa diminuição na temperatura de queima (economia de energia na produção).

A produção de materiais cerâmicos para a construção civil (especialmente tijolos) a custos menores, pode estimular a substituição da madeira empregada nas 
habitações locais, predominantes hoje na região. Tal substituição poderia auxiliar na desejada diminuição do desmatamento na região.

O ensaio de solubilização com as amostras queimadas contendo resíduos mostrou que a introdução do dregs e do grits, classificados pela atual legislação como "não inertes", à massa cerâmica, resultou em produto de estabilidade química atraente, inertizando quimicamente os resíduos. Esse fato é importante porque no caso do descarte de peças cerâmicas contendo os resíduos, na própria fabricação ou pósconsumo, os cacos e fragmentos gerados constituirão novos resíduos, mas desta vez de baixa agressividade ao meio ambiente. 


\section{REFERENCIAS BIBLIOGRÁFICAS}

ABTCP. Introdução aos processos de obtenção de celulose e fabricação de papel. São Paulo, ABTCP, 1999.

ALMEIDA, H.C. et al. Composição química de um resíduo alcalino da industria de papel e celulose (dregs). Revista, Química Nova vol. 30. n. 7. p 1669 1672. São Paulo, 2007.

ANDRADE,S.C.J; PASKOCIMAS, C. A. incorporação de resíduo sólido proveniente do polimento de grês porcelanato na indústria de cerâmica vermelha. In: 51 Congresso Brasileiro de Cerâmica. Salvador, ABC, 2007.

ANICER - Associação Nacional da Industria Cerâmica. Apresenta dados do setor em: <http://www.anicer.com.br>. Acesso em 04 de janeiro de 2010.

ASSOCIACAO BRASILEIRA DE NORMAS TECNICAS. NBR 15270-2. Blocos cerâmicos para alvenaria estrutural - Terminologia e requisitos. Rio de Janeiro, ABNT, 2005. 11p.

classificação. Rio de Janeiro, 2004. 77 p.

NBR 10004 Resíduos sólidos -

Janeiro, 2004. 7 p.

NBR 10005 Lixiviação de resíduos.Rio de

de Janeiro, 2004. 7 p.

NBR 10006 Solubilização de resíduos. Rio

NBR 10007 Amostragem de resíduos

$\overline{\text { solidos. Rio de Janeiro, 2004. } 7 \text { p. }}$

NBR 13894. Tratamento no solo. Rio de

Janeiro, 1997. 
.NBR 6220 - Material refratário denso

- determinação da massa específica aparente, porosidade aparente, absorção

e massa específica aparente da parte sólida. Rio de Janeiro,1997.

. NBR 11175. Incineração de resíduos

sólidos perigosos - Padrões de desempenho. 5 p. Rio de Janeiro, 1990.

BORLINI, M.C. et al. Caracterização de resíduo proveniente do beneficiamento de rochas ornamentais para incorporação em cerâmica argilosa. In: $52^{\circ}$ Congresso Brasileiro de Cerâmica. Florianópolis, SC, ABC, 2008.

BRACELPA.http://www.bracelpa.org.br/bra/saibamais/reflorestamento/index.ht ml . Ultimo acesso em 09/02/2010.

BRACELPA. Relatório Estatístico 2007/2008.São Paulo, BRACELPA, 2008.

BRACELPA. Responsabilidade socioambiental das empresas do setor de celulose e papel 2006. São Paulo, Bracelpa, 2007.

BRACELPA. Área florestal certificada alcança 1, 44 milhão hectares.Relatório Estatístico Florestal-2006

BRASIL.Ministerio do Meio Ambiente. .http://mapas.mma.gov.br/geonetwork/srv/br/graphover.show?id=32 9\&fname=fabrica ultima.png\&access=public.Ultimo acesso em 11 de janeiro de 2010.

BRASIL. Decreto 6514. Dispõe sobre as infrações e sanções administrativas ao meio ambiente, estabelece o processo administrativo federal para apuração destas infrações e da outras providencias. Brasília, Presidência da Republica, 2008.

BRASIL.Instituto Brasileiro de Geografia e Estatística - IBGE. Indicadores de desenvolvimento sustentável. Rio de Janeiro, IBGE, 2008.

BRASIL. Resolução Conama n 369 de 28 de março de 2006. Dispõe sobre os casos excepcionais, de utilidade pública, interesse social ou baixo impacto ambiental, que possibilitam a intervenção ou supressão de vegetação em Área de Preservação Permanente-APP.. Brasília, Conama, 2006. 
BRASIL. Resolução Conama 307. Brasília, CONAMA, 2006.

BRASIL. Resolução Conama n 357, de 17 DE MARÇO DE 2005. Dispõe sobre a classificação dos corpos de água e diretrizes ambientais para o seu enquadramento,bem como estabelece as condições e padrões de lançamento de efluentes, e dá outras providências.Brasilia, Conama, 2005.

BRASIL. Resolução Conama no 313 de 29 de outubro de 2002. Dispõe sobre o Inventário Nacional de Resíduos Sólidos Industriais. Brasília, Conama, 2002.

BRASIL. Resolução no 307/02. Estabelece diretrizes, critérios e procedimentos para a gestão dos resíduos da construção civil. Brasília, DF, CONAMA, 2002.

BRASIL. Lei $n^{\circ} 9.605$ de 12 de fevereiro de 1998. Dispõe sobre as sanções penais e administrativas derivadas de condutas e atividades lesivas ao meio ambiente, e dá outras providências. Brasília, Presidência da Republica, 1998.

BRASIL. Resolução Conama no 237 de 19 de dezembro de 1997. Dispõe sobre os procedimentos e critérios para licenciamento ambiental, e dá outras providências. Brasília, Conama, 1997.

BRASIL. Decreto 99.274, de 6 de junho de 1990. Regulamenta a Lei ${ }^{\circ} \quad 6.902$, de 27 de abril de 1981, e a Lei $n^{\circ} 6.938$ de 31 de agosto de 1981, que dispõem, respectivamente, sobre a criação de reservas ecológicas, e áreas de proteção ambiental e sobre a política nacional de meio ambiente, e dá outras providências. Brasília, DF, Presidência da Republica, 1990.

BRASIL. Lei $n^{\circ} 7.804$ de 18 de julho de 1989. Altera Dispositivos da Lei $n^{\circ}$ 6.938/1981que Dispõe sobre a Política Nacional do Meio Ambiente, seus fins e mecanismos de formulação e aplicação, e dá outras providências.Brasília, Presidência da Republica, 1981.

BRASIL. Lei no 6.938 de 31 de agosto de 1981. Dispõe sobre a Política Nacional do Meio Ambiente, seus fins e mecanismos de formulação e aplicação, e dá outras providências.Brasília, Presidência da Republica, 1981.

BRASIL. Lei 4771. Institui o novo Código Florestal. Brasília, Presidência da Republica, 1965. 
BRASILEIRO, M.I. et al. Avaliação dos Parâmetros de Queima na Formação da Mulita. In: $17^{\circ}$ CBECIMat - Congresso Brasileiro de Engenharia e Ciência dos Materiais, Foz do Iguaçu, PR, Brasil.2006,

CARDOSO, M. Unidade de recuperação (Licor negro, evaporadores e caldeira de recuperação). Curso de especializacao em papel e celulose. Belo Oriente, MG, ABTCP, 2001.

CELULOSE \& PAPEL. O uso de produtos químicos na fabricação do papel. Revista Celulose \& Papel, Curitiba, ano II, n. 3, p. 30-35, 2009

COSTA, E.O. et al. Percolação de poluentes em solos após aplicação de resíduos de fabrica de papel reciclado. REVISTA FLORESTA, Curitiba, v. 39. P. 409-418. 2009.

CUNHA, R. Tijolo de lodo é destaque em evento realizado em Porto Alegre. Revista da ULBRA. Porto Alegre, n. 112. 2003.

[DASKALOPOULOS, O.; PROBERT, S.D. Economic and Environmental Evaluations of Waste Treatment and Disposal Technologies for Municipal Solid Waste. Applied Energy, v. 58, n. 4, p. 209-255, 1997.

DEON, A.M. Medição do custo das perdas associadas ao processo produtivo de fabricação de celulose e papel. Dissertação (Mestrado).Universidade Federal de Santa Catarina. 2001.

DESCOLLI, JS.et al. A influencia do resíduo dregs da fabricação de papel na produção de argila expandida.In: $46^{\circ}$ Congresso Brasileiro de Cerâmica. São Paulo, ABC, 2002.

DORES, A.M.B. et al. Panorama Setorial: Setor Florestal, Celulose e Papel. Rio de Janeiro, BNDES, 2007.

ELLIOTT, A; MAHMOOD, T. Survey benchmarks generation, management of solid residues. Pulp \& Paper, Dec. 2005; 79; 12. 
ERENO, D. Resíduo construtivo. Lodo da industria de papel entra na composicao de materiais de construção. In: Revista Fapesp, Ed. $161 . \quad$ Julho 2009. p. $78-79$.

FOELKEL, C. Resíduos Sólidos Industriais do Processo de Fabricação de Celulose Papel de Eucalipto. Parte 02: Fatores de sucesso para seu gerenciamento. Eucalyptus Online Book \& Newsletter. São Paulo, ABTCP, 2008.

- Casca da árvore do eucalipto: aspectos morfológicos, fisiológicos, florestais, ecológicos e industriais, visando a produção de celulose e papel. EUCALYPTUS ONLINE BOOK \& NEWSLETTER. São Paulo, ABTCP, 2005.

GARLIPP, R. Eficiência, gestão, contratos e sustentabilidade na industria baseada em florestas plantadas. In: 430 Congresso da Sociedade Brasileira de Economia e Sociologia Rural. Ribeirão Preto, SOBER, 2005.

JUCON, S. VCP apresentou resultados alcançados com a adoção da ecoeficiencia em seu processo produtivo. Revista Meio Ambiente Industrial. São Paulo, v 21. 2006.

LANDIM, A.B. Reciclagem de resíduos sólidos. Parte 1: adição de dregs ao efluente do branqueamento acido.In: $27^{\circ}$ Congresso Anual de Celulose e papel. São Paulo, ABTCP, 1994.

LEITE, M.M. TCF System Closure. The Kvaemer Vision. In: Encontro Internacional de Branqueamento da Pasta Celulósica. Vitoria, ES, ABTCP, 1996.

LENGLER, H.C.et al. Caracterização comparativa de fundentes para emprego na Industria Cerâmica. São Paulo, Revista Cerâmica Industrial, 14 Julho/Agosto, 2009.

LENGLER, H.C. et al. Influencia do tipo de fundente sobre a porosidade final em cerâmicas tradicionais. In: $17^{\circ} \mathrm{CBECIMat}$ - Congresso Brasileiro de Engenharia e Ciência dos Materiais. Foz do Iguaçu, PR, 2006. 
MACHADO, C.C. et. al. Caracterização tecnológica de misturas solo-grits para pavimentos de estradas florestais: influência do tratamento térmico do grits na resistência mecânica das misturas. Revista Arvore, Viçosa, MG, vol. 31. n. 3, p.487-494, 2007.

MACHADO, R.; JORDAO, J.A.R.; NASCENTE, P.A.P. Determinação quantitativa de fases cerâmicas por difratometria de raios $X$. In: III Congresso Brasileiro de Engenharia e Ciência dos Materiais, 14, $2000 . \quad$ Anais.São Pedro, SP, p. 601-609.

MAIA, A.A.B. et al. Utilização de rejeito de caulim da Amazônia na síntese da zeólita A. Revista Cerâmica vol.53 no.327 São Paulo July/Sept. 2007

MILLER, C.P.; CHAGAS, G.; XAVIER, C.C. Determinação da eficiência em artefatos cerâmicos fabricados com argila de Campos dos Goytacazes - RJ. In: $18^{\circ}$ Congresso Brasileiro de Engenharia e Ciência dos Materiais. Porto de Galinhas, PE, CBCimat, 2008.

Kozievitch, V.F.J et al. Propriedades cerâmicas em corpos de cerâmica vermelha, produzidos com taguá de Jundiaí e lodo de estação de tratamento de esgotos domiciliares. In: $51^{\circ}$ Congresso Brasileiro de Cerâmica. Salvador, ABC, 2007.

MARGEM, J.I. et al. estudo do resíduo da estação de tratamento de água de itaperuna para incorporação em artefatos cerâmicos. In: $51^{\circ}$ Congresso Brasileiro de Cerâmica. Salvador, ABC, 2007.

MODOLO, R. C. E. Valorização de resíduos do sector de pasta e papel em produtos da construção civil. 2006. 119p. (Dissertação de Mestrado) Universidade de Aveiro, Portugal. [acesso em 21 Setembro 2009]. Disponível em <http://biblioteca.sinbad.ua.pt/teses/2007001047>.

MONTE, M.C. et al. Waste management from pulp and paper production in the European Union. Waste Management, 29, p. $\quad$ 293-308. Madri, 2009.

MORETTI, J. Queima em caldeira de resíduos sólidos (lodo) retirados na estação de tratamento de efluentes. São Paulo, ABTCP, 1995.

NOLASCO, A.M. Resíduos sólidos. Piracicaba: Departamento de Ciências Florestais, 2006. $1 \mathrm{v}$. 
NORTH COAST UNIFIED. PULP MILL - AIR QUALITY MANAGEMENT DISTRICT. NORTH COAST UNIFIED, 1999.

NURMESNIEMI, H. et. al. The use of a sequential leaching procedure for heavy metal fractionation in green liquor dregs from a causticizing process at a pulp mill. 2005. Finland. Chemosphere, p.1475-1484.

OLIVEIRA FILHO, A.C. Resíduos sólidos gerados diretamente dos processos industriais. In: $30^{\circ}$ Congresso Anual de Celulose e Papel. São Paulo, ABTCP, 1997.

PAIVA, S.N. Compósito cimento-lodo de ETE de industria de papel para aplicação na construção civil. Dissertação (Mestrado). Escola Superior de Agricultura Luiz de Queiroz / USP. Piracicaba, 2005.

PINTO, S. DE J. F. Valorização de resíduos da indústria da celulose na produção de agregados leves. 2005. 118p. (Dissertação de Mestrado) Departamento de Engenharia Cerâmica e do Vidro - Universidade de Aveiro, Portugal. [acesso em 21 Setembro 2009]. Disponível em <http://biblioteca.sinbad.ua.pt/teses/2007000206>.

PIOTTO, Z. C. Eco-eficiência na Indústria de Celulose e Papel - Estudo de Caso. 2003. 379p. (Doutorado em Engenharia, Área de concentração em Engenharia Hidráulica e Sanitária) - Escola Politécnica da Universidade de São Paulo, São Paulo. [acesso em 21 Setembro 2009]. Disponível em <http://www.teclim.ufba.br/site/material_online/teses/tese_zeila_c_piotto. pdf>.

REIS, J.P.; FOLGUERAS, M.V.; WEHLE, M.; CORREIA, S.L.. Incorporação de escória de alto-forno e vidro reciclado em cerâmica vermelha. In: $51^{\circ}$ Congresso Brasileiro de Cerâmica. Salvador, ABC, 2007.

ROCHA, S.S. Sustentabilidade na industria brasileira de papel e celulose. Uma analise comparativa entre empresas nacionais e transnacionais. Dissertação (Mestrado em Economia). Univ. Estadual Paulista "Julio de Mesquita Filho", Araraquara, SP, 2006.

STAPPE, J.L.; BALLONI, E.A. O uso de resíduos da industria de celulose como insumos na produção florestal. IPEF no 40. p. 33-37. São Paulo, 1988. 
SANTOS, E.S. et al. Obtenção de corantes utilizando resíduo da industria de papel e celulose. In: 44 Congresso Brasileiro de Cerâmica, $\quad$ São Pedro, SP, 2000.

SENAI - Departamento Regional de São Paulo; IPT - Centro Técnico em Celulose e Papel. Tecnologia de fabricação da pasta celulósica. Coordenação Técnica: Maria Luiza Otero D’Almeida. São Paulo, IPT, 1981. 2 v.

SGARBI, F. Produtividade do Eucalipto em função do estado nutricional e da fertilidade do solo em diferentes regiões do Estado de São Paulo. Dissertação (Mestrado). Escola Superior de Agricultura Luiz de Queiroz / USP. Piracicaba, 2002.

SOARES, J.M.D. et al. Adição de resíduo de industria fumageira na massa para produção de cerâmica vermelha. In: $47^{\circ}$ Congresso Brasileiro de Cerâmica. João Pessoa, PB, ABC, 2003.

SOARES, J.M.D. et al. Resistência mecânica e absorção de água de produtos de cerâmica vermelha produzidos na região central do estado do Rio Grande do Sul. In: $47^{\circ}$ Congresso Brasileiro de Cerâmica. João Pessoa, PB, ABC, 2003.

SOUZA SANTOS, P.; VIEIRA COELHO, A. C. - Argilas como catalisadores industriais - uma revisão - $1^{\circ}$ parte - Revista Brasileira de Eng. Química, 11, (2), 35-44 1988.

SOUZA SANTOS, P. Tecnologia de Argilas. Vol. 1. Ed. Da Universidade de São Paulo, EDUSP, São Paulo, SP, Brasil, 1975. Cap. 10.

STEINER, C. et al. Resíduos sólidos industriais ou bens de produção - o conceito da Riocell. In: $21^{\circ}$ Congresso Anual de Celulose e Papel. Guaiba, ABTCP, 1988.

TAVEIRA, L.M.B.O. Considerações de projeto e implantação do aterro industrial da Cenibra. In: $27^{\circ}$ Congresso Anual de Celulose e Papel. São Paulo, ABTCP, 1994.

VALCEMIRO, N. Disclosure ambiental: uma analise do conteúdo dos relatórios ambientais de empresas do setor de celulose. 192 p. Tese (Doutorado). Depto. Contabilidade. Universidade de São Paulo, 2002. 
VIEIRA, C.M.F. et al. Características e efeito da fração granulométrica < $2 \mu \mathrm{m}$ no comportamento de queima de uma argila. Revista Cerâmica, vol. 53, n. 327, São Paulo, July//sept., 2007.

VIEIRA, C.M.F. et. al. Incorporação de Lama de Alto Forno em Cerâmica Vermelha. In: $51^{\circ}$ Congresso Brasileiro de Cerâmica. Salvador, ABC, 2007.

VITAL, M.H.F. Florestas independentes no Brasil. BNDES Setorial. Rio de Janeiro, BNDES, 2009.

XAVIER, G.C. et al. Peças cerâmicas vermelhas com adição de resíduo de mármore moldadas por prensagem. Otimização por planejamento fatorial $3^{2}$. In: 47 Congresso Brasileiro de Cerâmica. João Pessoa, PB, ABC, 2003. 